\title{
A TESE 2 DE MARX SOBRE FEUERBACH. NOTAS PARA UM COMENTÁRIO
}

José Barata-Moura ${ }^{1}$

$\S 1$. Os textos.

São umas folhitas de papel com uns rabiscos. Numa caligrafia nada fácil de decifrar.

Engels encontrou esta peça num caderno de notas constante do espólio de Marx, que abrange o período entre 1844 e 1847 . Deve ter sido redigida no exílio de Bruxelas em $1845^{2}$, antes, no entanto, da composição de A ideologia alemã. Em qualquer caso, é posterior à Sagrada família, saída em Fevereiro de 1845, mas elaborada, ainda em Paris, entre Setembro e Novembro de 1844.

O manuscrito refere, no cabeçalho: «1. ad Feuerbach». Engels deu-lhe por título: «Teses sobre Feuerbach» (Thesen über Feuerbach).

Trata-se de umas simples nótulas. Sem revisão estilística, nem desenvolvimento. Com pequenas alterações redaccionais, foram publicadas pela primeira vez por Engels, em 1888, como Anexo ao Ludwig Feuerbach ${ }^{3}$. O original só veio a ter edição nos anos 20 do século $\mathrm{XX}^{4}$.

O ajuizamento global de Engels é conhecido, e reflecte, com correcção, os traços fundamentais:

\footnotetext{
1 Barata-Moura é um filósofo consagrado. Consagrado nacional e internacionalmente: tendo sido reitor da Universidade de Lisboa (1998-2006), em cujo Departamento de Filosofia leciona como professor catedrático, é membro de respeitadas associações e academias científico-filosóficas europeias, participa de congressos e simpósios em todo o mundo e tem a seu crédito substantiva bibliografia.

2 Para pormenores quanto à datação: Bert ANDRÉAS, «Marx et Engels et la gauche hégélienne», VIII, Annali dell'Istituto Giangiacomo Feltrinelli, Milano, VII (1964-1965), p. 434.

${ }^{3}$ Cf. Friedrich ENGELS, Ludwig Feuerbach und der Ausgang der klassischen deutschen Philosophie. Revidirter Sonder-Abdruck aus der "Neuen Zeit". Mit Anhang: Karl Marx über Feuerbach, vom Jahre 1845, Anhang., Marx über Feuerbach (niedergeschrieben in Brüssel im Frühjahr 1845); Stuttgart, Verlag von J. H. W. Dietz, 1888, pp. 69-72.

${ }^{4}$ Cf. Arkhiv Marksa i Engelsa, Moscovo, I (1924), respectivamente, pp. 203-207 e 208-210, bem como Marx-Engels Archiv, Frankfurt am Main, I (1926), respectivamente, pp. 222-226 e 227-230.
} 
«São notas [Notizen] para posterior elaboração [Ausarbeitung], assentadas à pressa [rasch hingeschrieben], absolutamente não destinadas à impressão [Druck], mas inestimáveis [unschätzbar] como o primeiro documento onde está consignado o germe genial [der geniale Keim] da nova visão do mundo [neue Weltanschauung].».

A meu ver, estas Teses, representando embora um «início», condensam o ponto de chegada de um atribulado percurso, e constituem um ponto de amarração para um vasto programa de ulteriores expedições. Contêm um esboço de questões centrais para o enfoque e a determinação daquilo que, doravante, assumirá o viso (e a dinâmica) de um materialismo novo: de um materialismo dialéctico.

Subsidiariamente - a esta luz, e no seu conjunto --, as Teses facultam também um imprescindível horizonte ontológico (dialéctico-materialista) de inteligibilidade para «a crítica da filosofia pós-Hegel» (die Kritik der nachhegelschen Philosophie) ${ }^{6}$, que, em A ideologia alemã, conhecerá um momento alto de sedimentação.

O presente ensaio ocupa-se somente da Tese 2.

Recordo, por isso, os textos disponíveis.

Segundo o manuscrito de Marx, de 1845:

«A questão de se ao pensar humano cabe verdade objectiva [gegenständliche Wahrheit] não é nenhuma questão da teoria, mas uma questão prática. O ser humano tem que provar, na prática, a verdade - isto é, [a] realidade [efectiva, Wirklichkeit] e [o] poder [Macht], [a] citerioridade [Diesseitigkeit] - do seu pensar. A querela acerca da realidade [efectiva] ou da não realidade [efectiva] do pensar - [do pensar] que está isolado da prática - é uma questão puramente escolástica.»?

\footnotetext{
5 «Es sind Notizen für spätere Ausarbeitung, rasch hingeschrieben, absolut nicht für den Druck bestimmt, aber unschätzbar als das erste Dokument, worin der geniale Keim der neuen Weltanschauung niedergelegt ist.», ENGELS, Ludwig Feuerbach und der Ausgang der klassischen deutschen Philosophie (1888), Vorbemerkung; Marx-Engels Werke, ed. IML (doravante: MEW), Berlin, Dietz Verlag, 1975, vol. 21, p. 264.
}

6 Cf. Karl MARX, Zur Kritik der politischen Ökonomie. Erstes Heft (1859), Vorwort; Marx-Engels Gesamtausgabe, ed. Günter Heyden e Anatoli Jegorow (doravante: MEGA²), Berlin, Dietz Verlag, 1980, vol. II/2, p. 102.

7 «Die Frage, ob dem menschlichen Denken gegenständliche Wahrheit zukomme - ist keine Frage der Theorie, sondern eine praktische Frage. In der Praxis muß der Mensch die Wahrheit, i. e. Wirklichkeit und Macht, Diesseitigkeit seines Denkens beweisen. Der Streit über die Wirklichkeit oder

\begin{tabular}{|l|l|l|l|l|}
\hline Qonista Dialectus & Ano 5 & n. 12 & Janeiro - Julho 2018 & p. 46-108 \\
\hline
\end{tabular}


Na versão publicada por Engels, em 1888:

«A questão de se ao pensar humano cabe verdade objectiva não é nenhuma questão da teoria, mas uma questão prática. O ser humano tem que provar, na prática, a verdade - quer dizer: a [efectiva] realidade e [o] poder, a citerioridade - do seu pensar. A querela acerca da realidade [efectiva] ou da não realidade [efectiva] de um pensar, que se isola da prática, é uma questão puramente escolástica.» ${ }^{8}$.

\section{§ 2. Verdade objectiva.}

Em debate, nesta segunda tese, está um relevante conjunto de questões que se prendem com «a verdade objectiva» (die gegenständliche Wahrheit).

$\mathrm{Na}$ Teoria do Conhecimento, o tema possui largo cadastro, e recebe, na literatura extensamente produzida, as «soluções» mais desencontradas. Tanto no que se refere ao estatuto da «verdade», como no que tange a objectividade do «verdadeiro».

A platónica remissão do assunto para «a planície da verdade» ( $\square \square$

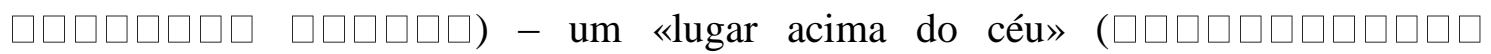
$\square \square \square \square \square$ ), por onde as Ideias hipostasiadas deambulariam em restaurativo passeio ${ }^{9}$-sossega aparentemente as almas inquietas pelo respectivo paradeiro, mas deixa o mundo dos sentidos desprovido da sua exibição integral e ao vivo, uma vez que «a verdade» ( $\square$ $\square \square \square \square \square \square \square$ ) é tomada como sinónimo de «aquilo que é» ( $\square \square \square \square$ ), da «entidade» $(\square \square \square \square \square)$, não sendo, por isso, de todo atributo dos «corpos visíveis» ( $\square \square \square \square \square$ $\square \square \square \square \square \square)^{10}$, os quais, na sua deveniência múltipla, apenas oferecem algo de fugaz,

Nichtwirklichkeit des Denkens - das von der Praxis isoliert ist - ist eine rein scholastische Frage.», MARX, Thesen über Feuerbach (1845), 2; MEW, vol. 3, p. 5.

8 «Die Frage, ob dem menschlichen Denken gegenständliche Wahrheit zukomme, ist keine Frage der Theorie, sondern eine praktische Frage. In der Praxis muß der Mensch die Wahrheit, das heißt die Wirklichkeit und Macht, die Diesseitigkeit seines Denkens beweisen. Der Streit über die Wirklichkeit oder Nichtwirklichkeit eines Denkens, das sich von der Praxis isoliert, ist eine rein scholastische Frage.», MARX Thesen über Feuerbach (1888), 2; MEW, vol. 3, p. 533.

${ }^{9}$ Cf. PLATÃO, Fedro, 248 b e 247 c, bem como Fédon, 109 e - 110 a.

10 Cf. PLATÃO, República, VII, 525 c-d.

\begin{tabular}{|l|l|l|l|l|}
\hline Qevista Dialectus & Ano 5 & n. 12 & Janeiro - Julho 2018 & p. 46-108 \\
\hline
\end{tabular}


que escorre, para perder-se, «no intervalo» $(\square \square \square \square \square \square)$ entre o «ser» $(\square \square \square \square \square)$ e o «não-ser» $(\square \square \square \square \square \square \square)^{11}$.

Ou seja: há «verdade» -- e até «objectiva» (porquanto os universais, como na Idade Média se dizia, são entendidos como realia ${ }^{12}$ ) --, mas ela não é deste mundo...

O aristotélico acantonamento da temática no plano da «judicação» proporciona outro arraial para os festejos, havendo o sítio ficado conhecido por «teoria clássica da verdade» ${ }^{13}$.

Sob um determinado ângulo, a qualidade de «verdadeiro» ( $\square \square \square \square \square \square)$ não está «nas coisas» ( $\square \square \quad \square \quad \square \square \quad \square \quad \square \quad \square \square \square \square \square$ ), «mas no entendimento» ( $\square \square \square, \square \square$ $\square \square \square \square \square \square \square$ ), posto que é a mente que, no juízo, opera «a ligação» ( $\square \square \square \square \square \square \square \square \square$ ), ou «a separação» ( $\square \square \square \square \square \square \square \square \square \square$ ) de sujeito e de predicado, constitutiva da forma proposicional que, só ela, pode aspirar ao qualificativo em apreço ${ }^{14}$.

Todavia - mesmo nos termos, e no termo, de uma dialéctica, para alguns, insuspeitada --, estes actos subjectivos de predicação não dispensam uma contrapartida no domínio da exterioridade ôntica:

«O verdadeiro ou o falso, no que toca às coisas [ $\square \square \square \square \square \square \square \square \square \square \square \square \square \square \square]$ ], consiste no estarem ligadas ou estarem separadas, de tal modo que fala verdade aquele que considera o separado como estando separado, e o ligado como estando ligado; porém, fala falso aquele que está [pensa] contrariamente [ $\square \square \square \square \square \square \square \square]$ ao que as coisas [são]. [...]. Com efeito, não é porque nós consideramos de modo verdadeiro

${ }^{11}$ Cf. PLATÃO, República, V, 476 e - 477 ab.

12 «Realismo - tal como a palavra é usada em conexão com a controvérsia medieval acerca de universais - é a doutrina platónica de que os universais, ou entidades abstractas, têm ser [being] independentemente da mente; a mente pode descobri-los, mas não os pode criar.» -- «Realism, as the word is used in connection with the mediaeval controversy over universals, is the Platonic doctrine that universals or abstract entities have being independently of the mind; the mind may discover them but cannot create them.», Willard van Orman QUINE, «On What There Is», From a Logical Point of View. LogicoPhilosophical Essays (1953), New York, Harper \& Row Publishers, $1963^{3}$, p. 14.

Fique, no entanto, como apontamento para outras discussões, que, segundo Platão -- e a despeito do que Quine sugere --, as $\cong \Leftrightarrow \Phi \therefore \forall 4$ não são obtidas «por abstracção» a partir do sensível, mas por uma inspecção directa, à qual dá o nome de «noese» $(<\overline{0} \Phi 4 \mathrm{H})$, um procedimento epistemológico, aliás, que lhes reforça o estatuto de autonomia entitativa. Cf. PLATÃO, República. VII, 534 a.

13 É nos termos desta «classicidade» que a teoria aparece acolhida num solo «semântico», por exemplo, por Alfred TARSKI, Die semantische Konzeption der Wahrheit und die Grundlagen der Semantik (1944), 3; Wahrheitstheorien. Eine Auswahl aus den Diskussionen über Wahrheit im 20. Jahrhundert, ed. Gunnar Skirbekk, Frankfurt am Main, Suhrkamp Verlag, 1980², pp. 142-143.

${ }^{14}$ Cf. ARISTÓTELES, Metafísica, E, 4, 1027 b 25-33.

\begin{tabular}{|l|l|l|l|l|}
\hline Qenista Dialectus & Ano 5 & n. 12 & Janeiro - Julho 2018 & p. 46-108 \\
\hline
\end{tabular}


[ $\square \square \square \square \square \square]$ que tu és branco, que tu és branco; mas, porque tu és branco, [é que] nós, que dizemos isso, falamos verdade.» ${ }^{15}$.

E é em torno do acampamento assim montado que Tomás de Aquino ergue a sua aconchegante paliçada teológica.

«Propriamente, a verdade está apenas no intelecto» (veritas proprie est in solo intellectu), e «as coisas são ditas verdadeiras a partir da verdade que em algun intelecto está» (res dicuntur verae a veritate quae est in aliquo intellectu) ${ }^{16}$. Só que este «algum» traz no porão escondida, de contrabando, a marosca a que se atrela o passe das mágicas pretendidas.

Aristotelicamente, «o verdadeiro» (verum) está «no intrelecto» (in intellectu) humano, «na medida em que ele seja conformado pela coisa inteligida» (secundum quod conformatur rei intellectae); mas, num assomo de metafísica cristianizada, os entes começam por ter que se conformar aos «exemplares» que mobilam o divino Intelecto criador:

«As coisas naturais» -- que medem a verdade do entendimento humano -- «são ditas verdadeiras, na medida em que acedem à semelhança [similitudo] das espécies que se encontram na mente divina» (res naturales dicuntur esse verae, secundum quod assequuntur similitudinem specierum quae sunt in mente divina $)^{17}$.

Em suma, é por esta razão, e por outras - em que, nomeadadamente, o episódio de Kant poderia ser à novela chamado ${ }^{18}$ - que «materialismo»e «realismo» não podem, com seriedade, ser tomados como categorias de significado equivalente.

$15 \ll \vartheta \in \square 802 \infty \mathrm{H} \times \mathrm{P} \gamma \neg * \cong \mathrm{H}, \quad \vartheta \cong \neg \vartheta \cong * ’ \mathrm{~B} \Re \quad \vartheta^{\mathrm{TM}}<\mathrm{B} \Delta \forall(: \varsigma \vartheta \mathrm{T}<f \Phi \vartheta \Re \quad \vartheta(\Phi \Lambda(6 \gamma \wp \Phi 2 \forall 4 \times$



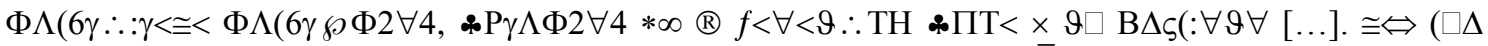
$* 4 \square \vartheta \in \equiv: \square \mathrm{H} \cong \cap \gamma \Phi 2 \forall 4 \square 802^{\text {TM }} \mathrm{H} \Phi \gamma 8 \gamma \Lambda 6 \in<\gamma \supset<\forall 4 \gamma \supset \Phi \cdot 8 \gamma \Lambda 6 \overline{\mathrm{H}}, \square 88 \square * 4 \square \vartheta \in \Phi \infty \gamma \supset<\forall 4$ $8 \gamma \Lambda 6 \in<\equiv: \gamma \wp \mathrm{H} \cong \supseteq v \varsigma_{\varsigma} \vartheta \gamma \mathrm{H} \vartheta \cong \neg \vartheta \cong \square 802 \gamma \beta \cong: \gamma<. »$, ARISTÓTELES, Metafísica, 1, 10, $1051 \mathrm{~b}$ 1-9.

16 Cf. TOMÁS DE AQUINO, Summa Theologiae (1266-1274), I, q. 16, a. 8.

17 Cf. TOMÁS DE AQUINO, Summa Theologiae, I, q. 16, a. 1.

Veja-se igualmente: TOMÁS DE AQUINO, Quaestiones disputatae de veritate, q. 1, a. 2.

18 Para Kant, «o idealista transcendental» (der transzendentale Idealist) é «um realista empírico» (ein empirischer Realist), na medida em que está pela respectiva doutrina autorizado a «admitir» (einräumen) «a existência da matéria» (die Existenz der Materie), «como fenómeno» (als Erscheinung) transcendentalmente constituído, «sem sair para fora da mera autoconsciência» (ohne aus dem bloßen Selbstbewußtsein hinauszugehen). Cf. Immanuel KANT, Kritik der reinen Vernunft (1781), Die transzendentale Dialektik, Der vierte Paralogism der Idealität (des äußeren Verhältnisse); A 370-372.

\begin{tabular}{|c|c|c|c|c|}
\hline Q Rovista Dialactus & Ano 5 & n. 12 & Janeiro - Julho 2018 & p. $46-108$ \\
\hline
\end{tabular}


Entendo deixar esta advertência, não por deslocados «preciosismos» de «recta pronúncia», mas porque, em frequentados meios de transpiração lexical anglo-saxónica, é infeliz costume entender a troca como pacificamente admissível ${ }^{19}$, e, por vezes até, desejável.

Entretanto, nos lugares de miudezas da praça gnosiológica, produtos de natureza bem diferente se oferecem em exposição nas bancadas, para deleite e consumo de outras freguesias.

Há quem sustente a integral subjectividade do «verdadeiro», porque, extremando a antiga sentença de Protágoras, segundo a qual «o homem é a medida [ $\square \square \square \square \square \square \square \square]$ de todas as coisas» ${ }^{20}$, nesse reduto antropológico de «impressões sensíveis» $\left(\square \square \square \square \square \square \square \square \square\right.$ ) se estabelece a irredutível pendência ${ }^{21}$, e se dirime o eventual

19 Como amostra do trato, uma declaração avulsa de emprego futuro, aparentemente cuidada no intento definitório:

«Usaremos, doravante, "materialismo" e "realismo" como designações [names] intertrocáveis [interchangeable] para aquela filosofia que sustenta que há um domínio [realm] natural: isto é, alguns objectos essencialmente independentes de toda a actividade humana, seja essa actividade pensamento, qualquer outra variedade de actividade mental, ou a actividade de produzir valores-de-uso para satisfação de precisões humanas.» -- «We shall, henceforward, use "materialism" and "realism" as interchangeable names for that philosophy which holds that there is a natural realm, i. e. some objects essentially independent of all human activity, whether that activity is thinking, any other variety of mental activity, or the activity of producing use-values for meeting human needs.», David-Hillel RUBEN, Marxism and Materialism. A Study in Marxist Theory of Knowledge (1977), III; Brighton - Atlantic Highlands (New Jersey), The Harvester Press - Humanities Press, $1979^{2}$, p. 66.

Para um panorama sucinto da recolocação hodierna do problema do «realismo» na literatura epistemológica, veja-se, por exemplo: Hans Jörg SANDKÜHLER, «Epistemologischer Realismus und die Wirklichkeit des Wissens. Eine Verteidigung der Philosophie des Geistes gegen Naturalismus und Reduktionismus», Wirklichkeit und Wissen. Realismus, Antirealismus und Wirklichkeits-Konzeptionen in Philosophie und Wissenschaften, ed. Hans Jörg Sandkühler, Frankfurt am Main - Bern - New York Paris, Peter Lang, 1992, pp. 187-210.

20 «O homem é a medida de todas as coisas: daquelas que são, tal como são; daquelas que não são, tal

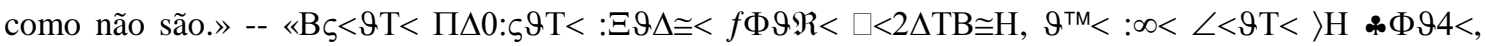
$\left.\vartheta^{\mathrm{TM}}<* \infty \cong \Leftrightarrow 6 \quad \angle<\vartheta \mathrm{T}<\right\rangle \mathrm{H} \cong \Leftrightarrow 6 * \Phi \vartheta 4<. »$, PROTÁGORAS, Fragmento B 1; Die Fragmente der Vorsokratiker, ed. Hermann Diels e Walther Kranz (doravante: FVS), Berlin, Weidmannsche Verlagsbuchhandlung, $1952^{6}$, vol. II, p. 263.

21 Como Sexto Empírico, a propósito da doutrina de Protágoras, refere, arrolando-o, assim, «no coro dos filósofos que fazem desaparecer o critério» ( $\vartheta\left(\Pi \cong \Delta\left(\vartheta^{\mathrm{TM}}<\square<\forall 4 \Delta \cong \beta<\vartheta \mathrm{T}<\vartheta \in \quad 6 \Delta 4 \vartheta \mathrm{Z} \Delta 4 \cong<\right.\right.$ $v 48 \cong \Phi \bar{v} \mathrm{~T}<$ ) da verdade:

«Todas as impressões sensíveis e [todas as] opiniões [* $>\forall 4$ ] são realmente $\left[\Downarrow_{\mathrm{B}} \varsigma \Delta \Pi \gamma 4<\right.$, por oposição a $v \forall \therefore<\gamma \Phi 2 \forall 4$ : parecer] verdadeiras $[\square 802 \gamma \wp \mathrm{H}$ ], e a verdade [ $\square 8 \mathrm{Z} 2 \gamma 4 \forall$ ] delas é algo de relativo [B $\Delta \in \mathrm{H} \vartheta 4$ ], porque tudo o que apareceu a alguém, ou foi opinado por [alguém], é logo real em relação a esse alguém.» -- «B $\varsigma \Phi \forall \mathrm{H} \vartheta \square \mathrm{H} v \forall<\vartheta \forall \Phi \therefore \forall \mathrm{H} 6 \forall \mathfrak{R} \vartheta \square \mathrm{H} * \overline{>} \forall \mathrm{H} \square 802 \gamma \wp \mathrm{H} \Downarrow \mathrm{B} \varsigma \Delta \Pi \gamma 4<6 \forall \mathfrak{R}$ $\vartheta^{\mathrm{TM}}<\mathrm{B} \Delta \overline{\mathrm{H}} \vartheta 4 \gamma \supset<\forall 4 \vartheta \leftarrow<\square 8 \mathrm{Z} 2 \gamma 4 \forall<* 4 \square \vartheta \in \mathrm{B} \square<\vartheta \in v \forall<\infty<\times * \overline{>} \forall<\vartheta 4<\mathfrak{R} \gamma \Leftrightarrow 2 \Xi \mathrm{TH} \mathrm{B} \Delta \in \mathrm{H}$

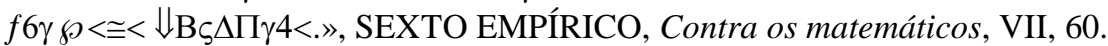

\begin{tabular}{|l|l|l|l|l|}
\hline Q Rovista Q Dialectus & Ano 5 & n. 12 & Janeiro - Julho 2018 & p. 46-108 \\
\hline
\end{tabular}


contencioso acerca dela, transferindo-se, de alguma maneira, o quesito da «comunicabilidade» para o terreiro agónico ${ }^{22}$ da «persuasão» $(\square \square \square \square \square)^{23}$, onde o instrumental argumentativo da «retórica» ${ }^{24}$ haveria de operar o triunfo da «verdade» própria sobre «as verdades» dos outros.

Numa chispa instaurativa de soberano decreto, há quem desvaneça em fumos a objectividade do verdadeiro, a pretexto de dar combate à «sacralização» (Heiligung) ${ }^{25}$ do que quer que seja que se nos ponha à frente como instância de um poder estranho, reverenciável apenas por uma consciência criadora que se ignore enquanto tal, e que, nessa míngua, servilmente se prontifique a genuflectir submissa perante o alheio ${ }^{26}$.

O mote tem patriarca. Releva de uma patente fichteana ${ }^{27}$, mas conhece em Max Stirner uma genuína versão assumidamente umbilicada.

${ }^{22} \mathrm{Na}$ ausência de um padrão meta-singular para as medidas, o conflito das interpretações devém a norma sempre presente:

«Acerca de toda a coisa, há dois discursos $[8 \overline{(\cong 4]}$ contrapostos $[\square<\vartheta 46 \gamma 4: \Xi<\cong 4]$ um ao outro.» -


Fragmento B 6 a; FVS, vol. II, p. 266.

${ }^{23} \mathrm{Na}$ Grécia antiga, os sofistas gozavam da generalizada fama de serem, na tribuna política e na barra dos tribunais, «mestres da persuasão» (B $\gamma 42 \cong \neg H * 4 * \varsigma \Phi 6 \forall 8 \cong 4)$. Cf., por exemplo, PLATÃO, República, II, $365 \mathrm{~d}$.

${ }^{24}$ Como, resumindo - não sem ironia -- o fundamental da arte oratória de Górgias, Sócrates adianta: «A retórica é uma obreira de persuasão» -- «B $\gamma 42 \cong \neg H * 0: 4 \cong \Lambda \Delta\left(\overline{\mathrm{H}} f \Phi \vartheta 4<\equiv \prod 0 \vartheta \cong \Delta 46 \mathrm{Z}\right.$ », PLATÃO, Górgias, 453 a.

${ }^{25}$ A relação entre o «senhorio» e a «sacralidade» tem referência bíblica conhecida. Veja-se, por exemplo, o Salmo 99.

26 «Estranheza [Fremdheit] é um distintivo do "sagrado" [Heiligen]. Em todo o sagrado, reside algo de "desconfortável" [etwas "Unheimliches"], quer dizer: algo de estranho [Fremdes], pelo que Nós não estamos totalmente à vontade [heimisch] e em casa [nossa]. Aquilo que Me é sagrado, não Me é próprio [eigen]»-- «Fremdheit ist ein Kennzeichen des "Heiligen". In allem Heiligen liegt etwas "Unheimliches", d. h. Fremdes, worin Wir nicht ganz heimisch und zu Hause sind. Was mir heilig ist, das ist Mir nicht eigen», Max STIRNER, Der Einzige und sein Eigentum (1844), I, II, 2, § 2; ed. Bernd Kast (doravante: EE), Freiburg-München, Verlag Karl Alber, 2009, p. 47.

«Perante o sagrado, perde-se todo o sentimento de poder [Machtgefühl], e toda a coragem [Mut]: comportamo-nos frente a ele de um modo impotente [ohnmächtig] e submisso [demütig]. E, contudo, nenhuma coisa é por si sagrada, mas pela Minha declaração de [que é] sagrado [Heiligsprechung], pela Minha sentença [Spruch], [pelo] Meu ajuizamento [Urteil], [pelo] Meu ajoelhar [Kniebeugen], em suma, pela Minha: consciência [moral, Gewissen].» -- «Vor dem Heiligen verliert man alles Machtgefühl und allen Mut: man verhält sich gegen dasselbe ohnmächtig und demütig. Und doch ist kein Ding durch sich heilig, sondern durch Meine Heiligsprechung, durch Meinen Spruch, Mein Urteil, Mein Kniebeugen, kurz durch Mein - Gewissen.», STIRNER, Der Einzige und sein Eigentum, I, II, 2, § 3; EE, p. 81.

${ }^{27}$ Baste recordar a inaugural posição do «Não-Eu» pelo «Eu»:

\begin{tabular}{|l|l|l|l|l|}
\hline Q Povista Qialectus & Ano 5 & n. 12 & Janeiro - Julho 2018 & p. 46-108 \\
\hline
\end{tabular}


«Des-sacralizar» significa inverter o pendor das «dependências»: reconhecer que «a verdade é uma criatura» (die Wahrheit ist eine Kreatur). Não propriamente porque no seu teor objectivo esteja incorporada feitura humana (como, aprofundando um vector pela Modernidade burguesa ensaiado ${ }^{28}$, Marx, com outra consistência no embasamento, destacará), mas, simplesmente, porque «ela não tem em si o seu valor» (sie ihren Wert nicht in sich hat). Precisa que alguém lho confira: «por si, ela está desprovida de valor» (für sich ist sie wertlos) $)^{29}$.

«O Eu é a fonte de toda a realidade. Somente por e com o Eu está dado o conceito da realidade.» -- «Aller Realität Quelle ist das Ich. Erst durch und mit dem Ich ist der Begriff der Realität gegeben.», Johann Gottlieb FICHTE, Grundlage der gesammten Wissenschaftslehre, als Handschrift für seine Zuhörer (1794), II, § 4, C; Werke, ed. Immanuel Hermann Fichte (doravante: W), reprod. Berlin, Walter de Gruyter \& Co., 1971, vol. I, p. 134.

Fichte dá ao materialismo a designação de «dogmatismo» (Dogmatismus), e transfere a questão ontológica para o domínio de uma ética, em que a liberdade se vê revestida de um poder instaurativo:

«O conflito entre o idealista e o dogmático é propriamente o de se, à autonomia do Eu, deve ser sacrificada a autonomia da coisa, ou [se], inversamente, à autonomia da coisa, [deve ser sacrificada] a autonomia do Eu.» -- «Der Streit zwischen dem Idealisten und Dogmatiker ist eigentlich der, ob der Selbstständigkeit des Ich die Selbstständigkeit des Dinges, oder umgekehrt, der Selbstständigkeit des Dinges die des Ich aufgeopfert werden solle.», FICHTE, Erste Einleitung in die Wissenschaftslehre (1797), 5; W, vol. I, p. 432.

28 Explorando as virtualidades descortinadas no modelo construtivo pela Geometria posto a uso, Hobbes, por transposição, havia justificado a possibilidade de um saber verdadeiro por parte da «filosofia social» (civil society), «porque nós próprios fazemos a comunidade» (because we make the commonwealth ourselves). Cf. Thomas HOBBES, Six Lessons to the Professors of the Mathematics (1656), Epistle Dedicatory; English Works, ed. William Molesworth, reprod. London, Routledge/Thoemmes Press, 1994, vol. VII, p. 184.

Veja-se igualmente: HOBBES, Elementorum philosophiae sectio secunda: De Homine (1658), X, 5; Opera Philosophica quae latine scripsit, ed. William Molesworth, reprod. Aalen, Scientia Verlag, $1966^{2}$, vol. II, p. 94.

A mesma perspectiva é, mais tarde, retomada, ou redescoberta, por Giambattista Vico, no quadro da sua concepção de que o «verdadeiro» (verum) é um «feito» (factum), ficando o conhecimento dele sob a alçada de quem lhe opere a «feitura»:

«O verdadeiro divino é aquilo que Deus, ao conhecer, dispõe e gera, do mesmo modo que o verdadeiro humano será aquilo que o homem, ao novar, igualmente compõe e faz» -- «verum divinum est quod Deus, dum cognoscit, disponit ac gignit, ita verum humanum sit, quod homo, dum novit, componit item ac facit», Giambattista VICO, De antiquissima Italorum sapientia (1710), I, I; Opere Filosofiche, ed. Paolo Cristofolini (doravante: O), Firenze, Sansoni Editore, 1971, p. 63.

$\mathrm{O}$ «mundo natural» (mondo naturale) é obra divina, pelo que apenas deus é detentor de um saber acerca dele. Em contrapartida, «este mundo das nações, ou seja [este] mundo civil» (questo mondo delle nazioni, o sia mondo civile), «porque os homens o fizeram» (perché l'avevano fatto gli uomini), também «dele podiam conseguir a ciência os homens» (ne potevano conseguire la scienza gli uomini). Cf. VICO, Principi di scienza nuova, d'intorno alla commune natura delle nazioni (1744), I, 3; O, p. 461.

Marx conhecia, e tinha apreço pela obra de Vico, não deixando de lhe recomendar a leitura: cf. MARX, Brief an Ferdinand Lassalle, 28. April 1862, bem como Brief an Engels, 28. April 1862; MEW, vol. 30, respectivamente, pp. 622-623 e 227-228.

Para uma referência directa ao ponto aqui focado: MARX, Das Kapital. Kritik der politischen Ökonomie. Erster Band. Hamburg 1867, I, 4, 4; $\mathrm{MEGA}^{2}$, vol. II/5, p. 303.

${ }^{29}$ Cf. STIRNER, Der Einzige und sein Eigentum, II, II, 3; EE, p. 358.

\begin{tabular}{|c|c|c|c|c|}
\hline Qovista Dialectus & Ano 5 & n. 12 & Janeiro - Julho 2018 & p. $46-108$ \\
\hline
\end{tabular}


O foco é expeditamente deslocado da ontologia -- e até mesmo do processo em que a cognição consiste - para a esfera de um investimento axiológico por atribuição. E a «verdade» vê-se remetida para um simples depósito de inertes, aonde «o Único» se vai abastecer de uns materiais de construção:

«Nunca a verdade venceu, mas ela foi sempre o meu meio [Mittel] para a vitória, à semelhança da espada - “a espada da verdade”"30. A verdade está morta, [é] uma letra, uma palavra, um material [ein Material] que Eu posso consumir [verbrauchen]. Toda a verdade, por si, está morta, [é] um cadáver; ela só está viva, do mesmo modo que o meu pulmão está vivo, a saber: na medida da minha vitalidade própria [eigene Lebendigkeit]. As verdades são [um] material, como a erva boa ou a erva daninha: se [é] erva boa ou erva daninha, a decisão [die Entscheidung] acerca disso reside em Mim.» ${ }^{31}$.

Sem uma conexão directa conhecida com estas delirantes avarias do «unicismo» stirneriano, são encontráveis também outras minerações que, quanto ao entendimento da «verdade», exploram um filão aparentado.

Assim, há quem, dando uma pirueta ao conceito, negue a pertinência de uma verdade objectiva (no sentido de «propriedade» material do ser, ou mesmo até de uma «ideia», ou de um enunciado judicativo), para a converter num simples «dispositivo instrumental» que se veri-fica, sempre que -- mas só quando --, ela «contribui» para a consecução de um «objectivo» que alguém, subjectivamente, se propõe atingir ${ }^{32}$.

\footnotetext{
30 A expressão é recorrente em catequeses do porte de armas, segundo credos de vária observância (no Islão também), querendo significar o poder gladiatório da verdade doutrinária.

Enquanto fórmula, testamentariamente atestada, confesso que não a encontro. Todavia, não será impossível decantá-la, recorrendo à via metodológica dos compósitos.

O paulino brandir da «espada do espírito» como sendo «a palavra de Deus» (PAULO, Carta aos Efésios, 6, 17) parece combinar a jesuína declaração, perante um embaraçado Pilatos, de que «veio ao mundo para dar testemunho da verdade» (JOÃO, Evangelho, 18,37) com uma outra advertência, anterior na narrativa biográfica, de que ao mundo não teria vindo «para trazer a paz, mas a espada» (MATEUS, Evangelho, 10, 34).

Na subsequente história sagrada -- num seu registo mais profano --, a inquisitorial entrega ao braço secular prenunciava, ao entretanto sentenciado, a infausta iminência de espadeiramentos de outra índole...

31 «Niemals hat die Wahrheit gesiegt, sondern stets war sie mein Mittel zum Siege, ähnlich dem Schwerte ("das Schwert der Wahrheit"). Die Wahrheit ist tot, ein Buchstabe, ein Wort, ein Material, das Ich verbrauchen kann. Alle Wahrheit für sich ist tot, ein Leichnam; lebendig ist sie nur in derselben Weise, wie meine Lunge lebendig ist, nämlich in dem Maße meiner eigenen Lebendigkeit. Die Wahrheiten sind Material wie Kraut und Unkraut: ob Kraut oder Unkraut, darüber liegt die Entscheidung in Mir.», STIRNER, Der Einzige und sein Eigentum, II, II, 3; EE, p. 357.
}

32 «A verdade de uma ideia não é uma propriedade estagnante inerente nela. A verdade acontece a uma ideia. Ela torna-se verdadeira, é feita verdadeira, por acontecimentos [events]. A veridade [verity] dela é,

\begin{tabular}{|l|l|l|l|l|}
\hline Qovista Q Dialectus & Ano 5 & n. 12 & Janeiro - Julho 2018 & p. 46-108 \\
\hline
\end{tabular}


Como William James - assombrosamente, mas com expedito desassombro declara:

«Uma ideia é "verdadeira", enquanto [so long as] acreditar nela [to believe it] for proveitoso [profitable] para as nossas vidas.»"

$\mathrm{Ou}$, segundo a formulação de um outro confrade garimpeiro, com escavações, na altura, no couto oxoniense:

«No que respeita aos objectos avaliados [valued] como "verdadeiros", Verdade é aquela manipulação [manipulation] deles que, depois de teste [upon trial], se vem a confirmar [to turn out] ser útil [useful]» ${ }^{34}$.

E, tal como a procura do lucro é a fonte motora que mantém em movimento as engrenagens dentadas do modo capitalista de produção, assim também -- à luz «moral» de um «dever-ser» convenientemente traduzido em «dever-ter»--, no que à verdade toca, o nobre desejo de a ela chegar se consuma, e justifica, nos e pelos «benefícios» (benefits), por experiência atestados, que cada um na sua «vidinha» vai conseguindo obter:

«A nossa obrigação [obligation] de procurar a verdade faz parte da nossa obrigação geral de fazer aquilo que compensa [to do what pays]. As compensações [payments] que as ideias verdadeiras trazem são o único porquê [why] do nosso dever [duty] de as seguir.» ${ }^{35}$.

«Verdadeiro»é «aquilo que compensa» (what pays), e, por conseguinte, os «bem recompensados» estão seguramente «na verdade». Nas oficinas do pragmaticismo

de facto, um acontecimento, um processo: nomeadamente, o processo de ela própria se verificar, [o processo] da sua veri-ficação. A validade dela é o processo da sua valid-ação.» -- «The truth of an idea is not a stagnant property inherent in it. Truth happens to an idea. It becomes true, is made true by events. Its verity is in fact an event, a process: the process namely of its verifying itself, its veri-fication. Its validity is the process of its valid-ation.», William JAMES, Pragmatism's Conception of Thruth (1907); Essays in Pragmatism, ed. Alburey Castell (doravante: EP), New York, Hafner Publishing Company, 1948, p. 161.

33 «An idea is "true" so long as to believe it is profitable to our lives.», JAMES, What Pragmatism means (1907); EP, p. 155.

34 «As regards the objects valued as "true", Truth is that manipulation of them which turns out upon trial to be useful», Ferdinand Cunning Scott SCHILLER, Truth (1902); Humanism. Philosophical Essays, London, Macmillan and Co., 1903, p. 61.

35 «Our obligation to seek truth is part of our general obligation to do what pays. The payments true ideas bring are the sole why of our duty to follow them.», JAMES, Pragmatism's Conception of Truth (1907); EP, p. 174.

\begin{tabular}{|l|l|l|l|l|}
\hline Q Ponista Qialectus & Ano 5 & n. 12 & Janeiro - Julho 2018 & p. 46-108 \\
\hline
\end{tabular}


(ideologicamente alinhavado), confecciona-se - com maior ou menor sofisticação nos figurinos --, para «a verdade» vigente, todo um guarda-roupa recomendado para aquele pronto-a-extorquir, na ordem estabelecida: «verdadeiro».

E, claro está, há ainda a mole daqueles despachados vivaços na lida com «o que importa», para quem - como Hegel dizia de Pôncio Pilatos, interpretando-lhe a réplica no diálogo com Jesus ${ }^{36}$-- nem vale a pena colocar-se o problema, porque a verdade é «uma coisa convencionada, da qual nós já nos livrámos» (ein Abgemachtes, mit dem wir fertig sind $)^{37}$. Vamos, portanto, «ao que interessa», que alhures está, e não precisa que a gente se preocupe com questiúnculas que apenas servem de entretém aos ociosos...

Enfim, há leituras, e tresleituras, de todos os feitios, para comprazimento de outras tantas sensibilidades.

E é neste emaranhado de teceduras - aqui não exaustivamente aludidas - que o deslindamento das meadas tem que processar-se.

No contorno materialista em que Marx situa o seu enfoque ontológico, «verdade objectiva» denota a correspondência do subjectivamente pensado -- num processo dialéctico de interacções, que nada têm de automatismo linear - com a materialidade do ser.

Ou seja - e a despeito das intenções visadas por outros entendimentos da questão --, não se trata apenas da consistência do pensado com o pensado (da lógica coerente de um discurso), ou da «tonalidade» subjectiva do assentimento que acompanha aquilo que se pensa (o respeitável cuidado pela certeza).

Todas estas dimensões integram o complexo novelo da verdade, reflectindo uma pluralidade de aspectos que, na instância própria para que remetem, não podem ver-se negligenciados. Todavia, no que diz respeito à verdade objectiva, é imprescindível não perder de vista aquilo que na sua determinação é determinante.

\footnotetext{
36 Segundo o relato joânico da conversa, Jesus teria dito: «todo aquele que é da verdade» -- B $\square \mathrm{H} \AA L f 6$ $\vartheta \uparrow \mathrm{H} \square 8002 \gamma \therefore \forall \mathrm{H}$, omnis qui est ex veritate; na tradução de Lutero: «quem é da verdade» (wer aus der Wahrheit ist) -- «ouve a minha voz $[\vee \mathrm{T}<\mathrm{Z}$, vox, Stimme $] . »$. Ao que Pilatos replicou: «Que é a verdade?». Cf. JOÃO, Evangelho, 18, 37-38.

37 Cf. Georg Wilhelm Friedrich HEGEL, Vorlesungen über die Geschichte der Philosophie (1833-1836), Einleitung; Theorie Werkausgabe, red. Eva Moldenhauer e Kark Markus Michel, Frankfurt am Main, Suhrkamp Verlag, 1971, vol. 18, p. 33.
}

\begin{tabular}{|l|l|l|l|l|}
\hline Q Ponista Dialectus & Ano 5 & n. 12 & Janeiro - Julho 2018 & p. 46-108 \\
\hline
\end{tabular}


É acerca de um mundo materialmente objectivo que se pergunta pela verdade, e é na materialidade objectiva desse mundo que, por sua vez, o «verdadeiro» há-de lograr comprovação.

Temos a marcha encaminhada, mas o percurso reserva ainda dificuldades para as quais se impõe encontrar o respondimento adequado.

\section{§ 3. Transgressão do âmbito exclusivo da teoria.}

E o primeiro sobressalto aparece logo na advertência subsequente das Teses.

Ao contrário do esperado -- e, para certas almas, paradoxalmente -, a verdade objectiva não constitui «nenhuma questão da teoria» (keine Frage der Theorie).

A um primeiro olhar desarmado - e a uma consciência apetrechada em exclusivo com supostos hauridos do dispensário idealista --, a peremptória afirmação faz soar os alarmes da estranheza, se é que não mesmo da indignação.

A «verdade» releva do «conhecimento», tem nele a sua sede; e vem proclamarse, agora, que a objectividade dela transgride as fronteiras do território em que o próprio «conhecer» se instala?

Não estaremos, com este passo incauto, a precipitar-nos pelas ribanceiras de um «materialismo metafísico» em compungida romagem de saudade aos santos lugares perdidos de uma defunta e enterrada gnosiologia «primitiva», toscamente «pré-crítica»?

A interrogativa tem adeptos, e, sobremaneira, um endereço esforçadamente antimaterialista ${ }^{38}$.

\footnotetext{
${ }^{38}$ Preparando um ajeitamento idealista daquilo que a Marx há-de ser atribuído, as baterias são assestadas tacticamente, sobretudo, contra o materialismo de Engels e de Lénine.

Merleau-Ponty fala de «uma gnosiologia pré-hegeliana e mesmo prékantiana» (une gnoséologie préhégélienne et même prékantienne). Cf. Maurice MERLEAU-PONTY, Les aventures de la dialectique (1955), III; Paris, Éditions Gallimard, $1977^{2}$, p. 93.

Karl Korsch já tinha falado da necessária «crítica da concepção primitiva, pré-dialéctica, e mesmo pré-transcendental, da relação de consciência e ser» (Kritik der primitiven, vordialektischen und sogar vortranszendentalen Auffassung des Verhältnisses von Bewußtsein und Sein). Cf. Karl KORSCH, Der gegenwärtige Stand des Problems «Marxisnmus und Philosophie». Zugleich eine Antikritik (1930); Marxismus und Philosophie (1923), ed. Erich Gerlach, Frankfurt am Main - Köln, Europäische Verlagsanstalt, $1975^{6}$, p. 53.

Veja-se também, à luz destes enquadramentos: Leszek KOLAKOWSKI, Karl Marx und die klassische Definition der Wahrheit (1955); Traktat über die Sterblichkeit der Vernunft. Philosophische Essays, München, R. Piper \& Co. Verlag, 1967, pp. 51-80.
}

\begin{tabular}{|c|c|c|c|c|}
\hline Q Rovista Dialactus & Ano 5 & n. 12 & Janeiro - Julho 2018 & p. $46-108$ \\
\hline
\end{tabular}


Mas, sendo o nome de Kant amiúde invocado - para efeitos de póstuma lavagem de atentados à honra, contra ele nefandamente perpetrados --, talvez não seja de todo inconveniente perceber que ele próprio não deixa de colocar o problema, para lhe aviar, no entanto, uma «solução», subordinada decerto ao regime, e à arquitectura, do seu idealismo transcendental.

Kant apercebe-se com nitidez do «osso» que torna a digestão impossível, se o encerramento na imanência do lógico não fôr, de alguma maneira, quebrado.

Em termos operacionais, Kant adopta, como moldura para as suas incursões, o chamado «modelo clássico»: a verdade emerge somente no plano do «juízo» $(\text { Urteil })^{39}$, e enquanto «adequação» (Übereinstimmung) ao objecto a que se reporta ${ }^{40}$.

A definição não há-de, portanto, sofrer entorses de secretaria, mas logo a partir daí a coisa começa a ficar torcida, em virtude da exiguidade do espaço de manobra.

E Kant - como, aliás, é seu meritório hábito -- não enrodilha disfarces para iludir a dificuldade.

Aquele «outro», que se procura para emparelhar o baile, acaba por deixar-nos sempre de caras com um «mesmo», que se não abandonou:

«Ora, eu só posso porém comparar [vergleichen] o objecto [das Objekt] com o meu conhecimento, pelo facto de que eu o conheço. O meu conhecimento deve portanto comprovar-se a si próprio [sich selbst bestätigen], o que, porém, para a verdade, está ainda longe de ser suficiente. Pois, uma vez que o objecto está fora de mim [außer mir],

\footnotetext{
39 «Verdade ou aparência [ilusória, Schein] não estão no objecto na medida em que ele é intuído, mas no juízo [Urteil] acerca dele, na medida em que ele [objecto] é pensado. Pode, portanto, dizer-se -- decerto correctamente -- que os sentidos não erram: não porque eles ajuízem sempre correctamente, mas porque eles não ajuízam de todo.» -- «Wahrheit oder Schein sind nicht im Gegenstande, so fern er angeschaut wird, sondern im Urteile über denselben, so fern er gedacht wird. Man kann also zwar richtig sagen: daß die Sinne nicht irren, aber nicht darum, weil sie jederzeit richtig urteilen, sondern weil sie gar nicht urteilen.», KANT, Kritik der reinen Vernunft $\left(1781,1787^{2}\right)$, Die transzendentale Dialektik, Einleitung, I; A 293 , B 350.

Encontramos abordagens semelhantes - designadamente, no que toca ao estatuto do material ante-predicativo, decorrente da simples captação do «objecto próprio» de uma determinada faculdade --, por exemplo, em: ARISTÓTELES, Da alma, III, 6, 430 b 27-31, e TOMÁS DE AQUINO, Summa Theologiae, I, q. 16, a. 2.

40 «A explicação nominal da verdade» (die Namenerklärung der Wahrheit) é a de que ela «consiste na adequação de um conhecimento com o seu objecto» (in der Übereinstimmung einer Erkenntnis mit ihrem Gegenstande besteht). Cf. KANT, Kritik der reinen Vernunft $\left(1781,1787^{2}\right)$, Die transzendentale Logik, Einleitung, III; A 58, B 83.
}

\begin{tabular}{|l|l|l|l|l|}
\hline Q Ronista Qialectus & Ano 5 & n. 12 & Janeiro - Julho 2018 & p. 46-108 \\
\hline
\end{tabular}


e que o conhecimento está em mim [in mir], eu, no entanto, só posso sempre ajuízar [beurteilen] se o meu conhecimento do objecto se adequa ao meu conhecimento do objecto.» ${ }^{41}$.

Kant reconhece o incomodativo impasse nesta situação «de beco», mas propõese, não obstante, encontrar uma «saída»: dentro do próprio beco.

Salta então dos bastidores para o palco uma distinção técnico-lexical importante, nem sempre devidamente valorizada no seu alcance.

Trata-se da distinção entre «verdade formal» (formale Wahrheit) e «verdade material» (materiale Wahrheit).

A «verdade formal» consiste numa «concordância»(Zusammenstimmung) do conhecimento consigo mesmo -- em que se observa o respeito pelas suas regras, universais e abstractas, de funcionamento coerente (isto é, pelos princípios de nãocontradição e identidade, da razão suficiente, do terceiro excluído, etc. $)^{42}$--, e a «verdade material» remete para «a adequação» (die Übereinstimmung) de um dado conhecimento com o correspondente objecto determinado ao qual esse conhecimento se refere $^{43}$.

A diferença que este dispositivo categorial retrata no contraste permite a Kant, na passada, ocupar três posições estratégicas no monte, com influência útil subsequente no movimento das forças:

\footnotetext{
${ }^{41}$ «Nun kann ich aber das Objekt nur mit meinem Erkenntnisse vergleichen, dadurch daß ich es erkenne. Meine Erkenntnis soll sich also selbst bestätigen, welches aber zur Wahrheit noch lange nicht hinreichend ist. Denn da das Objekt außer mir und die Erkenntnis in mir ist: so kann ich immer doch nur beurteilen: ob meine Erkenntnis vom Objekt mit meiner Erkenntnis vom Objekt übereinstimme.», KANT, Logik, ein Handbuch zu Vorlesungen (1800), Einleitung, VII; Gesammelte Schriften, ed. Königlich Preussischen Akademie der Wissenschaften (doravante: Ak.), Berlin - Leipzig, Walter de Gruyter \& Co., 1923, vol. IX, p. 50.

42 «A verdade formal consiste unicamente na concordância do conhecimento com ele próprio, com total abstracção de todos os objectos por junto, e de toda a diferença deles.» -- «Die formale Wahrheit besteht lediglich in der Zusammenstimmung der Erkenntnis mit sich selbst bei gänzlicher Abstraktion von allen Objekten insgesamt und von allem Unterschiede derselben.», KANT, Logik (1800), Einleitung, VII; Ak., vol. IX, p. 51.

43 «Nesta adequação de um conhecimento com aquele objecto determinado ao qual ele é referido tem, porém, que consistir a verdade material.» -- «In dieser Übereinstimmung einer Erkenntnis mit demjenigen bestimmten Objekte, worauf sie bezogen wird, muß aber die materiale Wahrheit bestehen.», KANT, Logik (1800), Einleitung, VII; Ak., vol. IX, p. 51.
}

\begin{tabular}{|l|l|l|l|l|}
\hline Qevista Dialectus & Ano 5 & n. 12 & Janeiro - Julho 2018 & p. 46-108 \\
\hline
\end{tabular}


Banir do cardápio dos possíveis a existência de «um critério material universal» (ein allgemeines materiales Kriterium) para a verdade ${ }^{44}$, entregando-lhe a jurisdição ao poder de uma outra alçada;

surpreender aquele divórcio ontológico que afecta, no seu própro cerne, a lógica formal abstracta, e que infecta, por unilateralizada inerência, as pretensões exclusivistas do «formalismo» a uma arbitragem derradeira dos diferendos;

capacitar-se, na embalagem do comboio - e para eventual espanto de viajantes mais distraídos -- de que, para chegar ao encontro do ser, é, ao fim e ao cabo, preciso colher informações que obrigam a sair «para fora da lógica» (außer der Logik) ${ }^{45}$.

Resumindo o alcance da manobra:

A simples correcção formal de um conhecimento não é suficiente para nos dar a verdade material dos objectos do conhecimento.

O desfecho operativo a que Kant aporta está, de resto, em consonância com toda uma larga tradição, que, depois, em recortes doutrinários diferentes -- de Aristóteles ${ }^{46}$ a Locke $^{47}$-- se explicita:

44 «Um critério materal universal da verdade não é possível: ele é mesmo em si próprio contraditório.» -«Ein allgemeines materiales Kriterium der Wahrheit ist nicht möglich; es ist sogar in sich selbst widersprechend.», KANT, Logik (1800), Einleitung, VII; Ak., vol. IX, p. 50.

Com efeito, como Kant também «explica», o critério, para ser universal, precisaria de abstrair de todas as diferenças (sem o que incorreria em alguma «particularidade»), ao mesmo tempo que, para ser material - isto é, para decidir da adequação de um conhecimento dado ao objecto determinado ao qual esse conhecimento se reporta --, ele teria que ser determinado, e, portanto, que incluir as diferenças. Daí exclusão recíproca que o «combinado» envolve.

45 A passagem, que passo a referir, encontra-se montada sobre um subtil jogo de «significações» que o idioma alemão possibilita, e que Kant explora no seu emprego.

«Die Erkenntnis», enquanto substantivo feminino, denota, em português, «o conhecimento» em geral; «das Erkenntnis», a flexão que aqui é utilizada, enquanto substantivo neutro, traduz a «sentença» ou o «acórdão», que através de um «juízo» se expressa.

Kant constrói deliberadamente a mensagem - gnosiológica -- que pretende transmitir sobre esta polissemia, evocando-nos as situações próprias de um tribunal:

«Porque, porém, a mera forma da sentença [judiciária, die bloße Form des Erkenntnisses], por mais que ela [a forma] possa estar de acordo [übereinstimmen] com leis lógicas [mit logischen Gesetzen], está ainda longe de bastar [hinreichen], por esse facto, para constituir, para a sentença [judiciária, dem Erkenntnisse], verdade material (objectiva) [materielle (objektive) Wahrheit], ninguém pode atrever-se, meramente com a [ajuda da] Lógica [bloß mit der Logik], a ajuizar [zu urteilen] acerca de objectos [über Gegenstände], e a afirmar o que quer que seja [irgend etwas], sem ter obtido previamente [vorher] notícia fundada [gegründete Erkundigung] acerca deles: fora da Lógica [außer der Logik]» -- «Weil aber die bloße Form des Erkenntnisses, so sehr sie auch mit logischen Gesetzen übereinstimmen mag, noch lange nicht hinreicht, materielle (objektive) Wahrheit dem Erkenntnisse darum auszumachen, so kann sich niemand bloß mit der Logik wagen, über Gegenstände zu urteilen, und irgend etwas zu behaupten, ohne von ihnen vorher gegründete Erkündigung außer der Logik eingezogen zu haben», KANT, Kritik der reinen Vernunft $\left(1781,1787^{2}\right)$, Die transzendentale Logik, Einleitung, III; A 60, B 85.

\begin{tabular}{|c|c|c|c|c|}
\hline Qovista Dialectus & Ano 5 & n. 12 & Janeiro - Julho 2018 & p. $46-108$ \\
\hline
\end{tabular}


O critério material (sempre especificado) do conhecimento verdadeiro não pode dispensar «a experiência» (die Erfahrung).

Para tanto, há que ir «fora da Lógica».

Significa isso, porém, «abandonar» os aconchegos da consciência para sair a um «de-frontar» da materialidade do real?

Esta é, porventura, a pergunta-chave.

A questão do objecto é mesmo nuclear para Kant. O idealismo, subjectivamente assentado, que ele perfilha de modo algum se pretende «subjectivista».

Daí que a unidade do próprio objecto seja chamada a fundar a possibilidade «material»-- de uma convergência inter-subjectiva daqueles ajuizamentos que em torno dele gravitam.

O encontro das subjectividades cognoscentes não é fruto de qualquer «pactação» subjectiva. O comunitariamente comum reveste um carácter objectivo:

«A pedra-de-toque do ter [alguma coisa] por verdadeiro» (der Probierstein des Fürwahrhaltens) -- «o fundamento da unissonância de todos os juízos, a despeito da diversidade dos sujeitos entre eles» (der Grund der Einstimmung aller Urteile, ungeachtet der Verschiedenheit der Subjekte unter einander) - repousa «sobre o

\footnotetext{
${ }^{46}$ O imprescindível concurso do «empírico» na atestação é veiculado por Aristóteles através da metáfora do tacto que, preendendo, apreende: «o verdadeiro» $(\vartheta \in \square 802 \Xi \mathrm{H})$ é «tocar em» $(24(\gamma \wp<)$, e «tornar visível pela palavra» $(v \varsigma<\forall 4)$; «o ignorar» $(\vartheta \in \square(<\cong \gamma \wp<)$ é «não tocar» $(: \leftarrow 24((\varsigma<\gamma 4<)$. Cf. ARISTÓTELES, Metafísica, 1, 10, 1051 b 24-25.

47 O paradigma da certificação vem-nos dado por aquele «conhecimento intuitivo» (intuitive knowledge) em que «a mente percebe o acordo ou desacordo de duas ideias imediatamente por elas próprias, sem a intervenção de nenhuma outra» -- «the mind perceives the agreement or disagreement of two ideas immediatly by themselves, without the intervention of any other», John LOCKE, An Essay concerning Human Understanding (1690), IV, II, 1; ed. Alexnder Campbell Fraser (doravante: HU), reprod. New York, Dover Publications, 1959, vol. II, p. 176.

Aliás, é este primado resolutivo da experiencialidade perceptiva directa que serve de alicerce aos bem-humorados ataques impiedosamente desferidos contra «uma espécie de filosofia, digna apenas de Sancho Pança, que tinha a faculdade de ver [to see] a Dulcineia, apenas por ouvir dizer [by hearsay]» -«a sort of philosophy worthy only of Sancho Pança, who had the faculty to see Dulcinea by hearsay», LOCKE, An Essay concerning Human Understanding, III, IV, 11; HU, vol. II, p. 38.

À saída de um hilariante diálogo travado com D. Quixote, o já confundido escudeiro acaba, de facto, por confessar que «a vista (la vista) que da excelsa senhora teve, afinal, «também foi de ouvido» (también fue de oídas). Cf. Miguel de CERVANTES SAAVEDRA, El Ingenioso Hidalgo Don Quijote De La Mancha (1605-1615), Parte II, c. IX; Obras Completas, ed. Juan Carlos Peinado, Madrid, Ediciones Cátedra, 2003, vol. I, p. 799.
}

\begin{tabular}{|l|l|l|l|l|}
\hline Q Ronista Qialectus & Ano 5 & n. 12 & Janeiro - Julho 2018 & p. 46-108 \\
\hline
\end{tabular}


fundamento comunitário, a saber: [sobre] o objecto» (auf dem gemeinschaftlichen Grunde, nämlich dem Objekte) $)^{48}$.

Ou, segundo a subsequente formulação dos Prolegómenos:

«Não haveria nenhum fundamento para que juízos de outros necessariamente [notwendig] tivessem que se adequar [übereinstimmen] com o meu, se não houvesse a unidade do objecto [die Einheit des Gegenstandes], ao qual todos eles se referem [beziehen], com o qual eles se adequam, e, por conseguinte, todos eles têm também que concordar [zusammenstimmen] entre si.» ${ }^{49}$.

Ficam, deste modo, montadas, no entanto, as peças para uma entrada triunfal do transcendentalismo apoteótico: o enredo em que a Crítica da razão pura se enreda.

A «objectividade» é transcendentalmente constituída no seu teor determinadonão por capricho arbitrário de cada um -, desde os níveis elementares da sensibilidade até aos «conceitos puros» da função sintética do entendimento ${ }^{50}$, no campo de uma consciência partilhada pelos seres racionais.

E neste transe se dissipa igualmente qualquer eventual «mistério» em volta do primado da «verdade transcendental». Ela não remete para nenhum «além» enigmático sobrepairante: institui - kantianamente - o aquém onde qualquer «experiência possível» (mögliche Erfahrung) tem que começar por firmar-se.

Como o próprio Kant sublinha:

«Todos os nossos conhecimentos jazem, porém, no todo [in dem Ganzen] de toda a experiência possível, e na universal referência [in der allgemeinen Beziehung] a

48 Cf. KANT, Kritik der reinen Vernunft $\left(1781,1787^{2}\right)$, Transzendentale Methodenlehre, 2, 3; A 820 821, B 848-849.

49 «Es wäre kein Grund, warum anderer Urteile notwendig mit dem meinigen übereinstimmen müßten, wenn es nicht die Einheit des Gegenstandes wäre, auf den sie sich alle beziehen, mit dem sie übereinstimmen, und daher auch alle unter einander zusammenstimmen müssen.», KANT, Prolegomena zu einer jeden künftigen Metaphysik, die als Wissenschaft wird auftreten können (1783), § 18; Ak., vol. IV, p. 298.

50 «Sem sensibilidade não nos seria dado objecto nenhum, e sem entendimento nenhum seria pensado. Pensamentos, sem conteúdo, são vazios; intuições, sem conceitos, são cegas.» -- «Ohne Sinnlichkeit würde uns kein Gegenstand gegeben, und ohne Verstand keiner gedacht werden. Gedanken ohne Inhalt sin leer, Anschauungen ohne Begriffe sind blind.», KANT, Kritik der reinen Vernunft $\left(1781,1787^{2}\right)$, Die transzendentale Logik, Einleitung, I; A 51, B 75.

\begin{tabular}{|l|l|l|l|l|}
\hline Q Ronista Dialectus & Ano 5 & n. 12 & Janeiro - Julho 2018 & p. 46-108 \\
\hline
\end{tabular}


ela consiste a verdade transcendental [die transzendentale Wahrheit] que precede toda a [verdade] empírica, e a torna possível.» ${ }^{51}$.

Conhecimento com verdade supõe «verdade transcendental», no sentido de que uma constituição transcendental do objecto em geral é condição indispensável para o escrutínio de qualquer conhecimento dado em termos de verdade material, ou seja: da sua adequação ao objecto de expreriência determinado.

Em suma, não podemos afirmar que o problema da necessária «transgressão» do domínio da mera formalidade do lógico esteja ausente das preocupações kantianas. Pelo contrário, ele não deixa de ser colocado: mas para, do mesmo passo, lhe ser por debaixo posta uma «diferenciação» que apenas no âmbito interno da consciência representativa sobrevém.

O desafio permanece intacto na realidade que continua a carecer de resposta.

Como se passa do «pensar que as coisas são assim» ao registo material de que «as coisas assim são»?

Há quem pense que ficar na «teoria» (por exemplo, com a experiência) basta.

Marx, como veremos, vai dizer que não chega.

§ 4. Consonâncias presumidas, que confundem.

Desalojada daquele agasalhado reduto nas intimidades acolhedoras da «teoria» -onde, de ordinário, a acondicionam --, a verdade objectiva devém, afinal, «uma questão prática» (eine praktische Frage).

$\mathrm{Na}$ aparência, o enunciado distingue-se pela clareza. Sobretudo, porque o leitor mais entusiasta, ou menos treinado na hermenêutica, tende a projectar sobre o adjectivo as conotações que nele espera estarem inscritas, em conformidade com o «espírito» que o arrebata, ou segundo aquilo que julga ser a óbvia significação do termo (que, além

\footnotetext{
${ }^{51}$ «In dem Ganzen aller möglichen Erfahrung liegen aber alle unsere Erkenntisse, und in der allgemeinen Beziehung auf diesselbe besteht die transzendentale Wahrheit, die vor aller empirischen vorhergeht, und sie möglich macht.», KANT, Kritik der reinen Vernunft $\left(1781,1787^{2}\right)$, Die transzendentale Analytik, II, 1; A 146, B 185.
}

\begin{tabular}{|l|l|l|l|l|}
\hline Q Ronista Qialectus & Ano 5 & n. 12 & Janeiro - Julho 2018 & p. 46-108 \\
\hline
\end{tabular}


disso, não questiona de todo). Toma-se o valor facial da moeda pelo crédito que a ela se atribui $^{52}$.

A formulação é, de facto, clara. Mas não dispensa o questionamento susceptível de lhe fazer ressaltar a fazenda que transporta.

Desde logo, porque, naquele entender em cujo âmbito Marx se movimenta, uma questão prática é ofício de transformação material, e, por conseguinte, não se resume a um protocolo de «experiência», a qual, enquanto observação empiricamente verificada, permanece submetida aos regimentos da «teoria».

E é justamente esta diferença que, nas Teses, Marx trata de pôr em destaque.

Alertar para este ponto - que, com alguma frequência, ao escrutínio habitual escapa -- torna-se ademais imprescindível, porquanto, no que ao uso vocabular respeita, Feuerbach diz coisas aparentemente «parecidas», ou que a um primeiro ouvido soam de uma maneira semelhante ${ }^{53}$.

Abundam, com efeito, as fórmulas feuerbachianas que se assinalam pela carga de dramatismo que veiculam, em curtos fretes que até aparentam relevar do trato com mercadoria ontológica:

«A questão acerca do ser [die Frage vom Sein] é, precisamente, uma questão prática [eine praktische Frage], uma questão em que o nosso ser está envolvido [como parte, beteiligt], uma questão de vida ou de morte [auf Tod und Leben].» ${ }^{54}$.

No sítio feuerbachiano da sua significação, estas expressões -- onde alguma coincidência literal é perceptível -- não dizem todavia (nem no todo, nem quanto ao teor das partes) o mesmo do que nas Teses se afirma.

${ }^{52}$ Como o sage Montaigne observava:

«A nossa opinião dá preço às coisas [...]. E chamamos valor, nelas, não ao que elas trazem, mas áquilo que nós para elas levamos.» -- «Notre opinion donne prix aux choses [...]. Et appelons valeur en elles, non ce qu'elles apportent mais ce que nous y apportons.», Michel Eyquem de MONTAIGNE, Essais (1580), I, 14; Oeuvres Complètes, ed. Robert Barral (doravante: OC), Paris, Éditions du Seuil, 1967, p. 41.

53 Também aqui poderíamos voltar a uma interlocução profícua com Montaigne:

«O valor da moeda muda, segundo o cunho e a marca do lugar.» -- «La valeur de la monnaie se change selon le coin et la marque du lieu.», MONTAIGNE, Essais (1580), III, 5; OC, p. 349.

54 «Die Frage vom Sein ist eben eine praktische Frage, eine Frage bei dem unser Sein beteiligt ist, eine Frage auf Tod und Leben.», Ludwig FEUERBACH, Grundsätze der Philosophie der Zukunft (1843), § 28; Gesammelte Werke, ed. Werner Schuffenhauer (doravante: GW), Berlin, Akademie-Verlag, 1982², vol. 9 , p. 308.

\begin{tabular}{|l|l|l|l|l|}
\hline Qenista Qialectus & Ano 5 & n. 12 & Janeiro - Julho 2018 & p. 46-108 \\
\hline
\end{tabular}


A «questão do ser», para Feuerbach - e, designadamente, nesta passagem --, remete, de facto, para a existência objectiva do real, candidamente identificado, no entanto, com a realidade do sensível, isto é, com aquela modalidade do aparecer ôntico que supõe, enquanto condição do seu re-conhecido estado de independência, um ser humano frente ao qual resiste, e que hospitaleiramente o acolhe.

É nesta estrada que o ser devém uma questão prática, não porque contenha nele trabalho humano de transformação incorporado, mas porque, na sua materialidade, entra na órbita de um interesse vital.

O mundo goza de um estatuto próprio, é certo; mas, na precisa medida em que enquanto onticamente distinto - constitui o tabuleiro indispensável à esfera subjectiva própria de um existir, onde a vida e a morte se decidem.

E as mefáforas bonitas prosseguem no seu desfile, ficando, no entanto, algo descomposta a entretela que lhes ampara uma certa firmeza no porte.

Tomemos como exemplo a feuerbachiana pose - de inegável recorte poético --, segundo a qual «o amor é o critério da verdade».

A despeito da pompa - deliberadamente escolhida, pelos harmónicos efeitos que à outiva sugere, e que deslumbram toda uma plateia de corações palpitantes --, este enunciado expressa, com fidelidade assinalável, o entendimento que Feuerbach revela da «prática», quando procede à sua convocatória para eventos desta índole:

«Porém, tal como objectivamente, assim também subjectivamente, o amor [die Liebe] é o critério do ser - o critério da verdade [das Kriterium der Wahrheit] e [da] realidade [Wirklichkeit]. Onde não [há] amor nenhum, não [há] também nenhuma verdade.» 55 .

O propósito desenha ao programa uma enternecedora aura de calor. Da verdade do conhecimento aos atestados da ontologia, hão-de todos os casos pendentes resolverse através de uma erotização discreta das sentimentalidades.

Efectivamente, é com este retrós que a proposta de Feuerbach se cose.

\footnotetext{
55 «Wie aber objektiv, so ist auch subjektiv die Liebe das Kriterium des Seins - das Kriterium der Wahrheit und Wirklichkeit. Wo keine Liebe, ist auch keine Wahrheit.», FEUERBACH, Grundsätze der Philosophie der Zukunft (1843), § 36; GW, vol. 9, p. 319.
}

\begin{tabular}{|l|l|l|l|l|}
\hline Qevista Dialectus & Ano 5 & n. 12 & Janeiro - Julho 2018 & p. 46-108 \\
\hline
\end{tabular}


Seria, no entanto, redutor - porque, na verdade, erróneo -- quedarmo-nos apenas pela impressão no invólucro estampada (a qual, de resto, não deixou de servir de vaga bengala a filadelfismos vários, nas suas peregrinações atmosféricas com uma coloratura pretendidamente $«$ socializante» ${ }^{56}$ ).

A estilização do amor cumpre em Feuerbach outras funções no enroupamento da sua teoria. E é essa que está em causa no exame crítico por Marx efectuado.

Importa, por isso, perguntar pela razão -- substancial, e não apenas decorativa -do feuerbachiano recurso a esta metafórica, que ele mesmo reconhece ter «significação metafísica, ontológica» (ontologische, metaphysische Bedeutung).

A resposta - no candor de que dá mostras - devém por completo elucidativa:

«O amor é paixão [Leidenschaft], e só a paixão é a marca [das Wahrzeichen] da existência [Existenz]. Só é aquilo que - real, ou possível - seja objecto [Objekt] da paixão. [...]. Assim, o amor é a verdadeira prova ontológica da existência [Dasein] de um objecto [ein Gegenstand] fora da nossa cabeça - e não há nenhuma outra prova do ser senão o amor, a sensação [die Empfindung] em geral.» ${ }^{57}$.

${ }^{56}$ Como Engels observava, num texto de 1847, que, no entanto, só veio a ser conhecido em 1929:

«A literatura socialista alemã torna-se de mês para mês pior. Ela restringe-se, cada vez mais, às expectorações achatadas [breite Expektorationen] daqueles socialistas verdadeiros, cuja sabedoria toda monta a uma amálgama de filosofia alemã e de sentimentalidade germano-porreiraça [deutschbiedermännische Sentimentalität $]$ com algumas raquíticas palavras-de-ordem comunistas.» -- «Die deutsche sozialistische Literatur wird von Monat zu Monat schlechter. Sie beschränkt sich immer mehr auf die breiten Expektorationen jener wahren Sozialisten, deren ganze Weisheit sich auf ein Amalgam deutscher Philosophie und deutsch-biedermännischer Sentimentalität mit einigen verkümmerten kommunistischen Stichwörtern beläuft.», ENGELS, Der Status quo in Deutschland (1847); MEW, vol. 4, p. 40 .

O fenómeno -- como, aliás, não fora esquecido (cf. ENGELS, Brief an Marx, 15. Januar 1847; $\mathrm{MEGA}^{2}$, vol. III/2, p. 83) - estava, no entanto, desde A ideologia alemã, identificado.

A sonora propaganda do «socialismo verdadeiro» (wahrer Sozialismus), dirigida «aos pequenoburgueses e às suas ilusões filantrópicas» (an die Kleinbürger und ihre philanthropischen Illusionen), assentava num desconhecimento palmar das realidades históricas (não investigadas), bem como numa confrangedora incompreensão da própria literatura socialista e comunista dos franceses e dos ingleses (falsificada), que estes «profetas» da «verdade» pretendiam «clarificar com a ajuda da ideologia alemã, nomeadamente, de Hegel e de Feuerbach» (mit Hülfe der deutschen, namentlich Hegelschen und Feuerbachschen Ideologie klarzumachen). Cf. MARX-ENGELS, Die deutsche Ideologie. Kritik der neuesten deutschen Philosophie in ihren Repräsentanten Feuerbach, B. Bauer und Stirner, und des deutschen Sozialismus in seinen verschiedenen Propheten (1845-1846), II, Der wahre Sozialismus; MEW, vol. 3, pp. 441-443.

Vejam-se, igualmente, dois outros escritos de 1847: ENGELS, Deutscher Sozialismus in Versen und Prosa e Die wahren Sozialisten (MEW, vol. 4, respectivamente, pp. 207-247 e 248-290), bem como: MARX-ENGELS, Manifest der Kommunistischen Partei (1848), III, c; MEW, vol. 4, pp. 485-488.

${ }^{57}$ «Die Liebe ist Leidenschaft, und nur die Leidenschaft ist das Wahrzeichen der Existenz. Nur was - sei es nun wirkliches oder mögliches - Objekt der Leidenschaft, das ist. [...]. So ist die Liebe der wahre ontologische Beweis vom Dasein eines Gegenstandes außer unserm Kopfe - und es gibt keinen andern

\begin{tabular}{|l|l|l|l|l|}
\hline Qevista Zialectus & Ano 5 & n. 12 & Janeiro - Julho 2018 & p. 46-108 \\
\hline
\end{tabular}


Se comprovação houvesse que fornecer, neste passo ela ficaria exibida. «Amor» e «sensibilidade» compõem um mesmo comportamento receptivo em que, e pelo qual, o estatuto de independência ontológica do «outro» é reconhecido.

E o feuerbachiano apelo à «impureza» de uns «actos» que é mister levar a cabo mais além dos remansos na redoma do «pensamento» -- não tem em vista também quaisquer labores transformativos, para a consecução dos quais fosse requerido algum eventual emporcalhar das mãos:

«Ao filósofo pertence, por conseguinte, não apenas o acto puro [actus purus] do pensar, mas também o acto impuro [actus impurus] ou misto [mixtus] da paixão, da receptividade sensível, a qual somente nos transporta à confluência universal [in den universalen Konflux] das coisas reais.» ${ }^{58}$.

Sumariando: à «lógica» do pensado há que substituir uma «estética» do sentido, e «o amor» é a tradução afectiva da «sensibilidade» (Sinnlichkeit). A «actividade» que se celebra consuma-se, afinal, em amorosa «passividade».

Com o estandarte nesta postura erguido, permanecemos, no entanto, e ainda, nos endógenos varandins da observação teórica, declinada embora num modo «empíricosensualista».

Para Feuerbach, aí há-de achar-se o critério.

Para Marx, não é neste endereço que ele mora...

\section{§5. «Diesseitigkeit».}

Beweis vom Sein als die Liebe, die Empfindung überhaupt.», FEUERBACH, Grundsätze der Philosophie der Zukunft (1843), § 34; GW, vol. 9, p. 318.

Tenha-se em conta que, em 1845, numa crítica que Engels dirige às concepções de Edgar Bauer (onde a deprecisação da objectividade material era notória), este enfoque «feuerbachiano» marca ainda presença. «O amor» (die Liebe) pode, assim, apresentar-se como emblema susceptível de traduzir «tudo o que está vivo» (alles Lebendige), «todo o imediato» (alles Unmittelbare), «toda a experiência sensível» (alle sinnliche Erfahrung), «toda a experiência [efectivamente] real» (alle wirkliche Erfahrung). Cf. ENGELS-MARX, Die heilige Familie, oder Kritik der kritischen Kritik. Gegen Bruno Bauer und Konsorten (1845), IV, 3; MEW, vol. 2, p. 23.

58 «Zum Philosophen gehört daher nicht nur der actus purus des Denkens, sondern auch der actus impurus oder mixtus der Leidenschaft, der sinnlichen Rezeptivität, die uns allein in den universalen Konflux der wirklichen Dinge versetzt.», FEUERBACH, Zur Beurteilung der Schrift "Das Wesen des Christentums" (1842); GW, vol. 9, p. 241.

\begin{tabular}{|c|c|c|c|c|}
\hline Qovista Dialectus & Ano 5 & n. 12 & Janeiro - Julho 2018 & p. $46-108$ \\
\hline
\end{tabular}


Antes de transitarmos à frase que, porventura, constitui o eixo fundamental do que nesta tese segunda está a ser pensado, permitam-me um apontamento rápido acerca da tradução de um vocábulo - sem grande rodagem, mas com algum préstimo -- que nela ocorre, e que remete para uma antitética bastante frequentada.

Ao nível da dogmática teológica, os exercícios de construção dicotómica do real - em clave bipartida entre um «aquém»e o «Além» -- dispõem certamente de amplos e variegados materiais escriturísticos para a arquitectura, até porque a bem-aventurança dos «pobres»e «famintos» neste mundo está caucionada escatologicamente pela «paga» ( $\square \square \square \square \square \square$, merces) que no outro irão receber (com retroactivos, e adicionais) ${ }^{59}$.

No registo estritamente terminológico, as categorias referidas, no entanto, não se distinguem por uma aparição de límpido recorte.

Apenas, no texto grego, do Apocalipse de João se revela a presença fugaz de um «de cá e de lá» ( $\square \square \square \square \square \square \square \square \square \square \square \square \square \square \square \square \square \square)^{60}$, num bosquejo de descrição paisagística.

A chamada Bíblia de Elberfeld traduz efectivamente estes termos por «diesseits und jenseits», mas a generalidade das lições, talvez por se tratar de um rio, prefere a versão da Vulgata: «de um e do outro lado» (ex utraque parte) ${ }^{61}$.

Embora neste episódio se encontre em causa o poiso da «árvore da vida» ( $\square \square \square \square \square \square \square \square \square$, lignum vitae), não parece de todo que ele esteja em condições de fornecer base de suficiente apoio para extrapolações «simbólicas» com um rebatimento topográfico de índole mais ambiciosa.

Inclino-me, por isso, a pensar que, para esta geração, e no ambiente cultural em que se formou, o elemento desencadeante das referências passa pelo modo hegeliano de conferir ao tema uma contextura determinada.

$\mathrm{Na}$ verdade, para Hegel, a Idade Média representa o momento privilegiado em que «o Espírito em si próprio doravante cindido» (der in sich selbst nunmehr entzweite

\footnotetext{
${ }^{59}$ Cf., por exemplo, LUCAS, Evangelho, 6, 20-23.

60 Cf. JOÃO, Apocalipse, 22, 2.

61 Na tradução de Lutero figura: «de ambos os lados da torrente» (auf beiden Seiten des Stromes).
}

\begin{tabular}{|c|c|c|c|c|}
\hline Qovista Dialectus & Ano 5 & n. 12 & Janeiro - Julho 2018 & p. $46-108$ \\
\hline
\end{tabular}


Geist) assume uma figura bifronte: «o mundo rasgado no aquém e [no] Além» (die in das Diesseits und Jenseits zerrissene Welt) ${ }^{62}$.

A desventurosa «consciência infeliz» (unglückliches Bewußtsein) padece ainda destes sofrimentos, na medida em que «sente dolorosamente a cisão» (die Entzweiung schmerzhaft fühlt), e em que «o movimento de uma ânsia infinda» (die Bewegung einer unendlichen Sehnsucht), que lhe contorce o íntimo, a aliena da sua «[efectiva] realidade própria» (eigene Wirklichkeit), sendo de todo incapaz de lhe permitir agarrar «o Além inalcançável» (das unerreichbare Jenseits $)^{63}$.

Com a Reforma de Lutero, e o advento consolidado de uma vivência burguesa do mundo - em que a ética deixa de exibir como «finalidade» (Zweck) o preguiçoso acomodamento à «pobreza» (Armut), mas «viver do seu trabalho» (von seiner Arbeit leben) se torna a consigna --, começa a chegar-se «à consicência da reconciliação» (zum Bewußtsein der Versöhnung) do aquém e do além: «a Terra e os corpos dela» (die Erde und ihre Körper) passam «a valer alguma coisa» (etwas zu gelten) ${ }^{64}$.

Com «as Luzes» (die Aufklärung) que no acontecer histórico a aprofundam, «o Reino repartido e espalhado no aquém e [no] Além» (das in das Diesseits und Jenseits verteilte und ausgebreitete Reich), «posto em desordem, e revolucionado» (verwirrt und revolutioniert), volta a conhecer uma unificação: «regressa à auto-consciência» (kehrt in das Selbstbewußtsein zurück) ${ }^{65}$.

O parêntese de uma longa noite de dissídio fecha-se, porque:

$\ll \mathrm{O}$ racional [das Vernünftige] tem que ter verdade objectiva [gegenständliche Wahrheit]. A reconciliação do Espírito com o mundo, a transfiguração [die Verklärung] da Natureza e de toda a realidade [efectiva], não têm que ser um Além [ein Jenseits], um algum-dia [ein Dereinst], mas têm que se completar agora e aqui.» ${ }^{66}$.

${ }^{62}$ Cf. HEGEL, Phänomenologie des Geistes (1807), VI; TW, vol. 3, p. 327.

Para uma explanação historiográfica destes dicotomismos, veja-se, designadamente: HEGEL, Vorlesungen über die Philosophie der Geschichte (1837, 1840²), IV, II; TW, vol. 12, pp. 440-491.

${ }^{63}$ Cf. HEGEL, Phänomenologie des Geistes, IV, B; TW, vol. 3, pp. 168-177.

64 Cf. HEGEL, Vorlesungen über die Geschichte der Philosophie (1833-1836, 1840-1844²), II, III, C; TW, vol. 20, p. 49.

${ }^{65}$ Cf. HEGEL, Phänomenologie des Geistes, VI; TW, vol. 3, p. 327.

66 «Das Vernünftige muß gegenständliche Wahrheit haben. Die Versöhnung des Geistes mit der Welt, die Verklärung der Natur und aller Wirklichkeit muß nicht ein Jenseits, ein Dereinst sein, sondern jetz und

\begin{tabular}{|l|l|l|l|l|}
\hline Qenista Qialectus & Ano 5 & n. 12 & Janeiro - Julho 2018 & p. 46-108 \\
\hline
\end{tabular}


Nestas atmosferas há-de entender-se a tirada enérgica com que David Friedrich Strauß conclui o seu tratado de Dogmática cristã, de 1841:

«O Além [das Jenseits] é decerto, em suma, o único inimigo [der Eine Feind] na sua figura de [inimigo] futuro, mas de último [inimigo] - que a crítica especulativa tem de combater e, se possível, derrotar [überwinden].» ${ }^{67}$.

Ao seu jeito, é ainda nesta esteira que o programa de Feuerbach se inscreve, e desenvolve.

De acordo com uma formulação tardia, tendo em conta o período que estamos a considerar:

«A finalidade dos meus escritos, bem como das minhas lições, é: fazer dos seres humanos, de teólogos, antropólogos; de teófilos, filantropos; de candidatos ao Além [aus Kandidaten des Jenseits], estudantes do aquém [zu Studenten des Jenseits]; de criados de quarto [Kammerdiener] religiosos e políticos da monarquia, e da aristocracia, celeste e terrena, cidadãos livres [freie Bürger], auto-conscientes [selbstbewußte], da Terra.» 68 .

No quadro da desmontagem das idealizações teológicas, celestialmente transpostas e hipostasiadas:

hier sich vollbringen.», HEGEL, Vorlesungen über die Geschichte der Philosophie (1833-1836, 1840$1844^{2}$ ), III, I, A; TW, vol. 20, p. 84.

67 «Das Jenseits ist zwar in allen der Eine, in seiner Gestalt als zukünftiges aber der letzte Feind, welchen die speculative Kritik zu bekämpfen und wo möglich zu überwinden hat.», David Friedrich STRAUSS, Die christliche Glaubenslehre in ihrer geschichtlichen Entwicklung und im Kampfe mit der modernen Wissenschaft (1841), Dogmatik, II, III, 2, § 110; ed. Werner Zager, Darmstadt, Wissenschaftliche Buchgesellschaft, 2009, vol. 2, p. 739.

68 «Der Zweck meiner Schriften, so auch meiner Vorlesungen, ist: die Menschen aus Theologen zu Anthropologen, aus Theophilen zu Philanthropen, aus Kandidaten des Jenseits zu Studenten des Diesseits, aus religiösen und politischen Kammerdienern der himmlischen und irdischen Monarchie und Aristokratie zu freien, selbstbewußten Bürgern der Erde zu machen.», FEUERBACH, Vorlesungen über das Wesen der Religion. Nebst Zusätzen und Anmerkungen (1851), 3; GW, vol. 6, pp. 30-31.

$\mathrm{E}$ as lições terminam por uma exortação, em que volta a ser lembrada «a tarefa» (die Aufgabe): converter os auditores «de amigos de deus em amigos dos homens; de crentes em pensadores, de suplicantes em operários, de candidatos ao Além em estudantes do aquém, de cristãos, que, segundo o seu credo e confissão próprios, são "meio animais, [e] meio anjos", em seres humanos, em seres humanos inteiros» -- «aus Gottesfreunden zu Menschenfreunden, aus Gläubigen zu Denkern, aus Betern zu Arbeitern, aus Kandidaten des Jenseits zu Studenten des Diesseits, aus Christen, welche ihrem eigenen Bekenntnis und Geständnis "halb Tier, halb Engel" sind, zu Menschen, zu ganzen Menschen», FEUERBACH, Vorlesungen über das Wesen der Religion, 30; GW, vol. 6, p.320.

\begin{tabular}{|l|l|l|l|l|}
\hline Qevista Dialectus & Ano 5 & n. 12 & Janeiro - Julho 2018 & p. 46-108 \\
\hline
\end{tabular}


«Assim como deus não é nada senão a essência do ser humano [das Wesen des Menschen], purificada daquilo que ao indivíduo humano - quer no sentimento, quer no pensar - aparece como barreira, como mal, assim o Além [das Jenseits] não é nada senão o aquém [das Diesseits], liberto daquilo que aparece como barreira [Schranke], como mal [ $\ddot{U} b e l] . »{ }^{69}$.

Mas esta contraposição - deslocada nos contornos -- desempenha igualmente um papel central na crítica feuerbachiana daquele «identitarismo» fundante das filosofias especulativas, que tudo pretendem resolver numa imanência pensada:

«A identidade do pensar e do ser expressa, por conseguinte, apenas a identidade do pensar consigo próprio. Quer dizer: o pensar absoluto não consegue sair de si [próprio], não sai fora de si [aus sich heraus] para o ser. O ser permanece um Além [ein Jenseits]. A filosofia absoluta bem nos fez do Além da Teologia um aquém, mas em troca disso [dafür] fez-nos do aquém do mundo real um Além.» ${ }^{70}$.

Portanto, independentemente dos matizes acentuados, e da variação introduzida, no guarda-roupa doutrinário, é-nos lícito assentar em que:

Jenseits significa «Além», e Diesseits quer dizer «aquém».

69 «Wie Gott nichts andres ist als das Wesen des Menschen, gereinigt von dem, was dem menschlichen Individuum, sei es nun im Gefühl oder Denken, als Schranke, als Übel erscheint, so ist das Jenseits nichts andres als das Diesseits, befreit von dem, was als Schranke, als Übel erscheint.», FEUERBACH, Das Wesen des Christentums (1841), I, Der christliche Himmel oder die persönliche Unsterblichkeit; GW, vol. 5, p. 309.

Como no texto da segunda edição também é referido:

«Aquilo que a fé nega no aquém da Terra, afirma-o ela no Céu do Além» -- «Was der Glaube im Diesseits der Erde verneint, bejaht er im Himmel des Jenseits», FEUERBACH, Das Wesen des Christentums (1843), Anhang; GW, vol. 5, p. 557.

Numa outra alusão a estes mecanismos compensatórios:

«Os habitantes de regiões nórdicas, frias, inamistosas, esperam, no Além, um clima mais ameno; os habitantes de países quentes, áridos, desprovidos de água, esperam, em contrapartida, no Além, sombras refrescantes, ventos, e fontes. Assim, na representação do Além, o ser humano suprime as barreiras, transtornos, e penosidades, locais da sua existência.» -- «Bewohner nördlicher, kalter, unfreundlicher Gegenden hoffen im Jenseits auf ein milderes Klima; Bewohner heißer, dürrer, wasserloser Länder dagegen hoffen im Jenseits auf kühlende Schatten, Winde und Quellen. So hebt der Mensch in der Vorstellung des Jenseits die örtlichen Schranken, Unannehmlichkeiten und Beschwerlichekeiten seiner Existenz auf.», FEUERBACH, Ergänzungen und Erläuterungen zum «Wesen der Religion» (1846); GW, vol. 10, p. 89.

70 «Die Identität von Denken und Sein drückt daher nur die Identität des Denkens mit sich selbst aus. Das heißt: Das absolute Denken kommt nicht von sich weg, nicht aus sich heraus zum Sein. Sein bleibt ein Jenseits. Die absolute Philosophie hat uns wohl das Jenseits der Theologie zum Diesseits gemacht, aber dafür hat sie uns das Diesseits der wirklichen Welt zum Jenseits gemacht.», FEUERBACH, Grundsätze der Philosophie der Zukunftr (1843), § 24; GW, vol. 9, pp. 302-303.

\begin{tabular}{|l|l|l|l|l|}
\hline Qenista Dialectus & Ano 5 & n. 12 & Janeiro - Julho 2018 & p. 46-108 \\
\hline
\end{tabular}


Ora, é precisamente aqui que - abstraindo da panóplia garrida dos concomitantes derivativos hermenêuticos (pelos quais, nesta altura, não me embrenho) - se perfila uma pequena dificuldade na tradução.

Com efeito, o termo por Marx empregue, na frase a que nos estamos a reportar, é: Diesseitigkeit.

Trata-se da substantivação de um adjectivo posicional -- «diesseitig»--, que, por sua vez, qualifica a «situação» cis-fronteiriça de algo que se encontre «do lado de cá», ou «d'aquém» (diesseits), de um determinado limite.

Num conjunto apreciável de situações ocorrentes, o nosso «aquém» vai dando para resolver o trivial das encomendas. Mas fabricar uma confusionista e mal-enjorcada: «aquenidade» está completamente para além do razoavelmente admissível, mesmo a um tradutor que se disponha a abusar das liberdades «poiéticas» ...

O problema, aliás, não é exclusivo da nossa pátria linguísitica. Subsiste também noutros idiomas. E, daí, o assinalável caudal de - encontradas, e desencontradas -versões com que nos deparamos.

Passo a apontar apenas uma amostragem não exaustiva.

Giovanni Gentile interpreta o vocábulo como «a positividade» (la positività) ${ }^{71}$, e Rodolfo Mondolfo como «a objectividade» (la oggettività $)^{72}$. Num passo em que parece aludir à expressão em apreço, Antonio Gramsci, por sua vez, fala de «uma imanência absoluta» (un'immanenza assoluta), que explica como «uma "terrestridade absoluta"» (una "terrestrità assoluta") ${ }^{73}$.

Albert Lévy traduz o conceito por «imanência» (immanence) $)^{74}$, um filão ao qual Pierre Macherey também recorre: «naturalidade imanente»(naturalité immanente) ${ }^{75}$.

71 Cf. Giovanni GENTILE, La filosofia della praxis (1899), 2; Opere filosofiche, ed. Eugenio Garin, Milano, Garzanti Editore, 1991, p. 145.

72 Cf. Rodolfo MONDOLFO, Feuerbach e Marx (1909), Il testo delle glosse, II; Umanismo di Marx. Studi filosofici 1908-1966, ed. Norberto Bobbio, Torino, Giulio Einaudi editore, $1975^{2}$, p. 10.

73 Cf. Antonio GRAMSCI, Quaderni del carcere, Quaderno 10 (1932-1935), § 31; ed. Valentino Gerratana (doravante: Q), Torino, Giulio Einaudi editore, 1975, vol. II, p. 1271.

74 Cf. Albert LÉVY, La philosophie de Feuerbach et son influence sur la littérature allemande, II, III; Paris, Félix Alcan Éditeur, 1904, p. 291.

75 Cf. Pierre MACHEREY, Marx 1845. Les «thèses» sur Feuerbach, Thèse 2; Paris, Éditions Amsterdam, 2008, p. 61.

\begin{tabular}{|l|l|l|l|l|}
\hline Qenista Dialectus & Ano 5 & n. 12 & Janeiro - Julho 2018 & p. 46-108 \\
\hline
\end{tabular}


Gilbert Badia, entretanto, optara pela perífrase bastante distendida: «neste mundo e para o nosso tempo» (dans ce monde et pour notre temps) ${ }^{76}$, enquanto Georges Labica usa de uma circunlocução mais curta: «o carácter terrestre» (le caractère terrestre $)^{77}$.

Por uma via análoga segue Álvaro Pina quando propõe: «o carácter terreno» ${ }^{78}$, e a generalidade das traduções castelhanas: «a terrenalidade» (la terrenalidad ${ }^{79}$. A partir do «deste lado» e do «desta mundaneidade» construiram-se em inglês duas «soluções»: «this-sidedness» ${ }^{80} \mathrm{e}$ «this-wordliness» ${ }^{81}$, que, em poupança de embaraços, me abstenho de traduzir.

Tanto quanto na minha ignorância do russo me posso aperceber, a divergência de Lénine relativamente à tradução de Plekhánov é mais interpretativa (há, de facto, um desfiguramento grave) do que «terminológica», na medida em que comprovar o carácter de aquém do pensamento aparece plekhanovianamente convertido em «comprovar que o pensamento "não se detém deste lado dos fenómenos" ${ }^{82}$.

76 Cf. MARX, Thèses sur Feuerbach; in MARX-ENGELS, L'idéologie allemande. Critique de la philosophie allemande la plus récente dans la personne de ses représentants Feuerbach, B. Bauer et Stirner, et du socialisme allemand dans celle de ses différents prophètes; trad. Henri Auger, Gilbert Badia, Jean Baudrillard, e Renée Cartelle, Paris, Éditions Sociales, 1968, p. 32.

77 Cf. Georges LABICA, Karl Marx. Les «Thèses sur Feuerbach», Traduction française du texte, 2; Paris, Presses Universitaires de France, 1987, p. 32.

78 Cf. MARX, Teses sobre Feuerbach, 2; MARX-ENGELS, Obras escolhidas em três tomos, dir. José Barata-Moura, Eduardo Chitas, Francisco Melo, e Álvaro Pina, Lisboa - Moscovo, Edições “Avante!” Edições Progresso, 1982, vol. I, p. 1.

79 Cf., por exemplo: MARX, Tesis sobre Feuerbach, 2; MARX-ENGELS, Obras escogidas, Moscú, Editorial Progreso, 1973, vol. I, p. 8, ou Juan Manuel BERMUDO ÁVILA, El concepto de praxis en el joven Marx, VI, III; Barcelona, Ediciones Península, 1975, p. 455.

80 Cf. Sidney HOOK, From Hegel to Marx. Studies in the Intellectual Development of Karl Marx (1950), VIII, 2; Ann Arbor, The University of Michigan Press, $1978^{6}$, p. 281.

${ }^{81}$ Cf., por exemplo, Nathan ROTENSTREICH, Basic Problems of Marx's Philosophy, 3, 2; Indianapolis - New York, Kansas City, The Bobbs-Merrill Company, 1965, p. 47; MARX, Theses on Feuerbach, 2; MARX-ENGELS, Collected Works, ed. Jack Cohen e outros (doravante: CW), Moscow, Progress Publishers, 1976, vol. I, p. 6, ou Wal SUCHTING, «Marx's Theses on Feuerbach: A New Translation and Notes Towards a Commentary», Issues in Marxist Philosophy, ed. John Mepham e David-Hillel Ruben, Brigthon, The Harvester Press, 1979, vol. II, p. 11.

82 Cf. Vladímir Ílitch LÉNINE, Materialismo e Empiriocriticismo. Notas críticas sobre uma filosofia reaccionária (1909), II, 1; trad. port. (doravante: ME), Lisboa-Moscovo, Edições «Avante!» - Edições Progresso, 1982, p. 78.

\begin{tabular}{|l|l|l|l|l|}
\hline Qenista Dialectus & Ano 5 & n. 12 & Janeiro - Julho 2018 & p. 46-108 \\
\hline
\end{tabular}


Confessando-me incapaz de elocubrar, em português, uma versão que mantenha o enraizamento lexical no «aquém», socorro-me de uma enxertia que recupera um ramo, proporcionado pelo latim, mas que, em dado troço, a nossa língua absorveu.

Do «cis» preposicional latino, que significa «aquém»(diesseits), chegou até nós o adjectivo «citerior» (citerior, disesseitig), razão pela qual me atrevo a traduzir «die Diesseitigkeit» por «a citerioridade», ou seja, a situação de algo numa topografia que, por contraste com um «além», nos remete para «o lado de cá».

Nesta segunda tese sobre que nos estamos a debruçar, ao referir a «citerioridade» do pensamento humano -- naquilo que ao cunho de verdade que pretenda assumir diga respeito --, Marx está, por conseguinte, a comunicar-nos dois aspectos de vincada relevância, e de desfecho nada simples.

Por um lado, a verdade não tem a residência fixa num «Além» celestial. Está domiciliada no «aquém».

Por outro lado, o verdadeiro não mora no bairro «da consciência» apenas. Firmase, ontologicamente, fora, aquém dela.

Que significa isto?

Que há uma verdade do mundo -- e não apenas dos «espíritos», d'aquém ou d'além túmulo --, e que esta verdade nos é acessível, o que, em vez de desvanecer a dificuldade, nos obriga a pôr o problema de como lá chegar...

\section{§ 6. A «provação» do conteúdo da verdade.}

Examinemos, com brevidade embora, as duas articulações fundamentais que nos passam a ser apresentadas: a conexão real (objectiva) daquilo que subjectivamente é conhecido no conhecer, e a mediação prática dos dispositivos de prova quanto ao acerto do assertado.

«A verdade» (die Wahrheit) de um pensamento consiste na capacidade que lhe seja inerente de - na forma subjectiva que assume - dar conta da «realidade [efectiva]» (Wirklichkeit) dos conteúdos que pensa, isto é, do seu efectivo «poder» (Macht) para tornarem inteligível aquilo que na interrogação se questiona.

\begin{tabular}{|l|l|l|l|l|}
\hline Qevista Dialectus & Ano 5 & n. 12 & Janeiro - Julho 2018 & p. 46-108 \\
\hline
\end{tabular}


A unidade material do ser - que uma ontologia materialista tem por esteio -funda a comensurabilidade do pensar e do real que o transcende, mas não garante, só por si, automatismo fatal à adequação concreta do reflexo concebido.

O processo epistemológico dispõe de uma esfera própria de dialéctico exercício: não é uma decorrência mecânica do observar passivo de alteridades que se nos impõem, mas também não constitui um andaime engenhoso de adivinhações acerca de um ser que principialmente sempre escapasse, em virtude de alguma irremovível «estranheza» decretada.

Compreender a verdadeira natureza - lábil, na sua relacionalidade interactiva, mas materialmente fundada ${ }^{83}$ - deste teatro de operações, em permanente estaleiro de

83 Para o materialismo - que Marx dialecticamente aprofunda --, a materialidade do ser não se identifica com a objectualidade sentida como «objectiva» no marco da consciência, ao contrário, por exemplo, do que a crença empirista supunha, e o transcendentalismo kantiano pensadamente compunha.

A diferença que entre os campos do «ser» e do «pensar» se abre, e subsiste, firma-se, ela própria, num quadro de unidade material, pelo que não é absolutamente intransponível. A materialidade não constitui, aliás, um sobejo (necessário, mas negligenciável), uma espécie de posta restante de real (que eventualmente se «admite» existir, mas sem nele haver penetração cognitiva possível).

O famigerado reflexo, por sua vez, não é uma entidade abracadábrica, nem uma ambulância de pronto-socorro que se chama em circunstâncias de aperto. Enquanto categoria gnosiológica, o reflexo visa precisamente traduzir o feixe de relações - e indicar, ao estudo, aquela trama de problemas - que se estabelecem na inter-acção entre sistemas materiais com forma específica diferente. Denota, portanto, um processo de mediação conectiva, e conhecente, que enlaça patamares endógenos do ser, qualitativamente distintos embora nas determinações que os constituem.

Mais do que uma solução pronta a deglutir, o reflexo aponta a direcção ontológica, na qual os percursos investigativos hão-de ter seguimento.

As repescagens intentadas do «kantismo», em clave «social-democratista» finissecular, navegam filosoficamente pelo lago - politicamente, a navegação foi efectuada também por outros charcos - de uma completa falta de entendimento desta dialéctica materialista.

Atente-se, por exemplo, no comentário - confusionista, indignado, e esperançoso -- que Conrad Schmidt «esclarecedoramente» expende, logo após a citação por extenso da tese 2:

«Que significa isto senão o facto [die Thatsache] de que nós reconhecemos na Natureza exterior conexão [Zusammenhang] e conformidade a leis [Gesetzmässigkeit], e que, através deste conhecimento, nós podemos operar sobre a Natureza de um modo conforme a finalidades [zweckmässig]; este facto prova já, de um modo claro como o Sol, que o nosso conhecimento da Natureza é um conhecimento do efectivamente real [wirklich Reale]; aquela dúvida [Zweifel] que o idealismo quanto a isso levanta não precisa sequer de ser cientificamente analisada e refutada, mas é simplesmente de atirar para o lado como sofisma [Vernünftelei] vazio! Isto, porém, não quer dizer triunfar sobre o idealismo, mas sair-lhe do caminho [para evitar o encontro].» -- «Was bedeutet das anders, als: die Thatsache, dass wir in der äusseren Natur Zusammenhang und Gesetzmässigkeit erkennen, und durch diese Erkenntniss auf die Natur zweckmässig einwirken können, diese Thatsache beweist bereits sonnenklar, dass unsere Naturerkenntniss eine Erkenntniss des wirklich Realen ist, jener Zweifel, den der Idealismus daran erhebt, braucht gar nicht wissenschaftlich analysirt und widerlegt $\mathrm{zu}$ werden, sondern ist einfach als leere Vernünftelei bei Seite zu werfen! Das heisst aber nicht, den Idealismus überwinden, sondern ihm aus dem Wege gehen.», Conrad SCHMIDT, «Ein neues Buch über die materialistische Geschichtsauffassung. Kritisches und Referirendes», Der sozialistische Akademiker, Berlin, II (1896), n. 7, p. 402.

Porque «a conformidade do mundo da experiência a leis» (die Gesetzmässigkeit der Erfahrungswelt) é por Kant colocada «no centro da consideração» (im Zentrum der Betrachtung) que empreende, ficaria não só satisfeito o requisito por Marx enunciado, como ainda, na passada, se

\begin{tabular}{|l|l|l|l|l|}
\hline Q Rovista Dialectus & Ano 5 & n. 12 & Janeiro - Julho 2018 & p. 46-108 \\
\hline
\end{tabular}


obra, torna-se, por conseguinte, um requisito capital na montagem e na condução dos procedimentos.

É possível conhecer as realidades em devir, mas o conhecimento não dispensa a fadiga dos trabalhos. Tanto ao nível da inquirição pelo estudo, da descoberta do posto a nu, e do pensar concebente que das concreções subjectivamente se apropria, como nos tabuleiros daquela comprovação que mede o alcance efectivo -- «o poder» (die Macht) - da inteligência teoreticamente alcançada.

Marx esboça-nos aqui, de facto, traves mestras de um enfoque materialista.

Penso que, numa passagem conhecida do Ludwig Feuerbach - que é pertinente a este propósito convocar --, Engels aclara o contexto (onto-gnosiológico e accional) de implantação destes debates.

Defrontando as posições daqueles que - designadamente, colhendo a inspiração de Hume ${ }^{84}$, ou de $\mathrm{Kant}^{85}$ - nos interditam «a possibilidade de um conhecimento do

apresentaria enriquecido, com vantagem, pelas aportações oriundas do idealismo «crítico» (leia-se: constituição transcendental dos objectos quanto ao seu teor determinado, e fundamento subjectivo da legalidade transcendentalmente im-posta, para vir a ser empiricamente re-descoberta).

Em suma, o alegado «complemento» gnosiológico idealista no texto anunciado, de facto, apenas serve de pretexto para uma expedita remoção ontológica do materialismo, entretanto, completamente mal-entendido no que se refere à sua constitutiva componente dialéctica.

${ }^{84}$ Para Hume, o conhecimento humano, insusceptível de legitimamente ir além da experiência subjectiva, tem, por isso, que se circunscrever «às aparições [appearances] de objectos aos nossos sentidos, sem entrar em indagações [disquisitions] acerca da sua real natureza e operações» -- «to the appearances of objects to our senses, without entering into disquisitions concerning their real nature and operations», David HUME, A Treatise of Human Nature (1739-1740), I, II, 5; ed. Alexander Dunlop Lindsay (doravante: THN), reprod. London - New York, J. M. Dent \& Sons - E. P. Dutton \& Co. (Everyman's Library), 1968, vol. I, p. 68. consciência:

O acesso à «externalidade» do objecto está-nos vedado. Deparamos apenas com «impressões» na

Uma vez que «nada está alguma vez realmente presente [junto] com a mente, a não ser as suas percepções ou impressões e ideias, e que os objectos externos se nos tornam conhecidos apenas por aquelas percepções que ocasionam [...], segue-se que é impossível para nós algo como [so much as] conceber ou formar uma ideia do que quer que seja [anything] especificamente diferente de ideias e [de] impressões.»-- «nothing is ever present with the mind but its perceptions or impressions and ideas, and that external objects become known to us only by those perceptions they occasion [...], it follows, that it is impossible for us so much as to conceive or form an idea of anything specifically different from ideas and impressions.», HUME, A Treatise of Human Nature, I, II, 6; THN, vol. I, p. 71.

$85 \mathrm{Na}$ moldura do transcendentalismo kantiano, a presença do material hilético é indispensável à afecção dos sentidos, enquanto «coisa em si» (Ding an sich) ou «númeno» (Noumenon), mas apenas nos é dado conhecer «representações» (Vorstellungen), uma vez que «aquilo que não é fenómeno não pode ser nenhum objecto da experiência» -- «dasjenige, was nicht Erscheinung ist, kein Gegenstand der Erfahrung sein kann», KANT, Kritik der reinen Vernunft $\left(1781,1787^{2}\right)$, Die Transzendentale Analytik, II, 3; A 246, B 303.

Curiosamente em todas estas diferentes abordagens continua a verificar-se a perdurância tutelar daquele arreigado paradigma aristotélico, segundo o qual a «matéria» $(\diamond 80)$ representa um constituinte

\begin{tabular}{|l|l|l|l|l|}
\hline Qovista Dialectus & Ano 5 & n. 12 & Janeiro - Julho 2018 & p. 46-108 \\
\hline
\end{tabular}


mundo» (die Möglichkeit einer Erkenntnis der Welt), posto que somente os «dados imediatos», ou os «construtos», da «consciência» representativa nos seriam acessíveis, Engels trata de recordar:

«O decisivo para a refutação [die Widerlegung] desta perspectiva foi já dito por Hegel, tanto quanto isso era possível do ponto de vista idealista ${ }^{86}$; aquilo que Feuerbach acrescenta de materialista é mais espirituoso [geistreich] do que profundo [tief] ${ }^{87}$. A mais concludente refutação desta [mania de nos vedar o acesso ao real], como de todas as outras tinetas filosóficas [philosophische Schrullen], é a prática [die Praxis], a saber: o experimento [das Experiment] e a indústria. Quando nós podemos provar a correcção [die Richtigkeit] da nossa concepção [Auffassung] de um processo natural, fazendo-o a ele próprio nós, produzindo-o a partir das suas condições, fazendo-o, acima de tudo, servir finalidades nossas, põe-se fim à inapreensível [unfaßbar] "coisa em si [Ding an sich]" de Kant.» ${ }^{88}$.

«necessário» $(\square<\forall(6 \forall \wp \cong<)$, mas «incognoscível» $(\square(<T \Phi \vartheta \stackrel{<}{<})$. Cf. ARISTÓTELES, Física, II, 9,200 a 14, e Metafísica, Z, 10, 1036 a 9.

${ }^{86}$ É precisamente rebatendo as posições de inspiração formalisto-subjectiva kantiana quanto à decretada inacessibilidade do ser que Hegel, assente na sua ontologia idealista -- porquanto converte «aquilo que é» em Geist --, replica:

«Porém, apenas a natureza do conteúdo [nur die Natur des Inhalts] pode ser aquilo que se move no conhecer científico, na medida em que, simultaneamente, é esta reflexão própria do conteúdo [eigene Reflexion des Inhalts] que, ela somente [erst], põe [setzen] e engendra [erzeugen] a sua própria determinação.» -- «Sondern es kann nur die Natur des Inhalts sein, welche sich im wissenschaftlichen Erkennen bewegt, indem zugleich diese eigene Reflexion des Inhalts es ist, welche seine Bestimmung selbst erst setzt und erzeugt.», HEGEL, Wissenschaft der Logik (1812), Vorrede; TW, vol. 5, p. 16.

${ }^{87} \mathrm{O}$ timbre de certas expressões feuerbachianas é, na verdade, bastante mais sonoro na promessa, do que propriamente fecundo na consistência daquilo que acaba por proporcionar.

Atentemos numa reflexão que remonta ao período de 1843-1844.

A retumbância lapidária do desfecho -- consagrando embora um abandono da crendice enquanto modo de respondimento eficaz - limita-se a devolver o desiludido perplexo a uma «experienciação» do viver, na trivialidade identificado com «a prática»:

«"A ciência não resolve o enigma da vida". Seja! Mas que se segue daí? Que tu desertas para a fé? Isso significaria sair da chuva para se pôr debaixo do algeroz. [Segue-se, pelo contrário] que tu passes para a vida, para a prática. $A$ dúvida que a teoria não resolve, a prática resolve-te.» -- «"Die Wissenschaft löst nicht das Rätsel des Lebens.” Meinetwegen; aber was folgt daraus? Daß du zum Glauben überläufst? Das hieße vom Regen in die Traufe kommen. Daß du zum Leben, zur Praxis übergehst. Die Zweifel, die die Theorie nicht löst, löst dir die Praxis.», FEUERBACH, Fragmente zur Charakteristik meines philosophischen curriculum vitae (1846); GW, vol. 10, p. 178.

O apelo, na intenção das palavras, está. Mas falta o conteúdo na orientação.

${ }^{88}$ «Das Entscheidende zur Widerlegung dieser Ansicht ist bereits von Hegel gesagt, soweit dies vom idealistischen Standpunkt möglich war; was Feuerbach Materialistisches hinzugefügt, ist mehr geistreich als tief. Die schlagendste Widerlegung dieser wie aller andern philosophischen Schrullen ist die Praxis, nämlich das Experiment und die Industrie. Wenn wir die Richtigkeit unsrer Auffassung eines Naturvorgangs beweisen können, indem wir ihn selbst machen, ihn aus seinen Bedingungen erzeugen, ihn

\begin{tabular}{|l|l|l|l|l|}
\hline Qevista Dialectus & Ano 5 & n. 12 & Janeiro - Julho 2018 & p. 46-108 \\
\hline
\end{tabular}


Aqui chegados, consintam-me que insista, porque, infelizmente, o reparo nem sempre se vê atendido:

Não será conveniente incorrer numa cadastrada tentação dupla: confundir «o experimento» (das Experiment) com «a experiência»(die Erfahrung), e, no tropel das balbúrdias, tomar a prática (que mediadamente transforma, no plano objectivo das realidades) como despachado sinónimo de uma «experienciação» (que imediatamente constata, num tabuleiro subjectivo).

A experiência - mesmo no caso de enquanto processo ser considerada -- ocorre no marco «teórico» de uma consciência que deixa «o mundo das coisas» intacto. $\mathrm{O}$ experimento intervém materialmente numa produção de coisas, transforma o «estado» em que elas se apresentam, vindo subsequentemente o resultado a poder tornar-se o termo visado numa «verificação» empírica.

«Provar»(beweisen) a verdade de um pensamento «na prática» (in der Praxis) não é apenas atestar empiricamente uma determinada «factualidade» vigente que lhe corresponda, que ele reflicta em moldes de correcção experienciada. A «prova» prática de um pensamento verdadeiro requer operações transformativas, através das quais a verdade que ele com-porta, e enuncia, se materializa em formas de realidade que com ele convêm.

Importa, por isso, não baralhar aquilo que a prática opera com aquilo que a observação empírica mostra, diluindo pela mistura o constitutivo momento de diferença que entre estas duas atitudes humanas no atender ao mundo subsiste, e que se revela determinante na compreensão do sentido materialista dialéctico que à abordagem dos problemas está aqui a ser imprimido.

O critério da verdade não é ver (num reduto, ainda que qualificado, de «teoria»): é fazer (o que reclama, e envolve, prática, transformação material).

Numa anotação de 1877 - que, posteriormente, veio a ser incluída na Dialéctica da Natureza -- Engels regressa ao tema, dando testemunho de como esta perspectiva,

obendrein unsern Zwecken dienstbar werden lassen, so ist es mit dem Kantschen unfaßbaren "Ding an sich" zu Ende.», ENGELS, Ludwig Feuerbach und der Ausgang der klassischen deutschen Philosophie (1888), II; MEW, vol. 21, p. 276.

\begin{tabular}{|l|l|l|l|l|}
\hline Qevista Dialectus & Ano 5 & n. 12 & Janeiro - Julho 2018 & p. 46-108 \\
\hline
\end{tabular}


por 1845 alcançada, passara entretanto a integrar o património ontológico consolidado das suas abordagens materialistas:

«A empiria da observação [die Empirie der Beobachtung] somente nunca pode provar suficientemente a necessidade. Post hoc [depois disto] não [é], porém, propter hoc [por causa disto] ${ }^{89}$ (Enc. I, 84) ${ }^{90}$. Isto está tão correcto que do constante nascer do Sol da manhã não se segue que ele amanhã volte a nascer, e, de facto, nós sabemos agora que virá um momento em que o Sol, uma manhã, não nasce. Mas a prova da necessidade reside na actividade humana, no experimento, no trabalho: quando eu posso fazer [machen] o post hoc, isso [esse fazer] torna-se idêntico com o propter hoc.» ${ }^{91}$.

89 Engels recorda a formulação latina que os Escolásticos deram ao vício (já por Aristóteles assinalado) -e que, porventura, não será apenas «lógico» -- de atribuir determinância causativa ao que não passa de mero antecendente «a-causante» $(\square<\forall \therefore \vartheta 4 \cong<)$ numa ordem de eventos que se sucedem.

Em conformidade com esta maneira algo simplificada de proceder - frequente entre «os [que

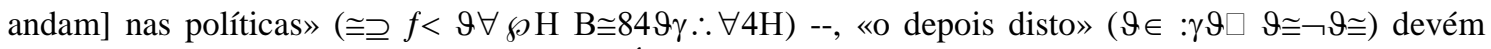
«por causa disto» $(* 4 \square \vartheta \cong \neg \vartheta \cong)$. Cf. ARISTÓTELES, Retórica, II, 24, 1401 b 29-34.

${ }^{90}$ Como Hegel refere, no passo da Enciclopédia ao qual Engels alude:

«Do mesmo modo, a empiria [die Empirie] proporciona decerto percepções [Wahrnehmungen] de modificações que se sucedem umas às outras [von aufeinanderfolgenden Veränderungen] ou de objectos que jazem uns ao lado dos outros [von nebeneinanderliegenden Gegenständen], mas não uma conexão da necessidade [ein Zusammenhang der Notwendigkeit]. Ora, na medida em que a percepção haja de permanecer a base [die Grundlage] daquilo que valha como verdade [Wahrheit], a universalidade e [a] necessidade aparecem como algo de injustificado [etwas Unberechtigtes], como uma casualidade subjectiva, um mero hábito, cujo conteúdo pode estar arranjado [beschaffen] assim, ou de outra maneira.» -- «Ebenso gewährt die Empirie wohl Wahrnehmungen von aufeinanderfolgenden Veränderungen oder von nebeneinanderliegenden Gegenständen, aber nicht einen Zusammenhang der Notwendigkeit. Indem nun die Wahrnehmung die Grundlage dessen, was für Wahrheit gelte, bleiben soll, so erscheint die Allgemeinheit und Notwendigkeit als etwas Unberechtigtes, als eine subjektive Zufälligkeit, eine bloße Gewohnheit, deren Inhalt so oder anders beschaffen sein kann.», HEGEL, Enzyklopädie der philosophischen Wissenschaften im Grundrisse (1830), § 39; TW, vol. 8, p. 111.

$\mathrm{O}$ trecho insere-se na desmontagem crítica hegeliana do encerramento de Hume na imediatez de uma experiência fragmentária, pelo que o nexo causal - inerente à processualidade das próprias coisas (e não kantianamente resultante de uma lei «transcendental») - nunca é percepcionado, mas apenas inferido de uma associação «habitual» que cada sujeito efectua.

À luz dos supostos da doutrina humeana, com efeito, «a mente nunca percebe nenhuma conexão real entre existências distintas» (the mind never perceives any real connection among distinct existences), uma vez que «todas as nossas distintas percepções são existências distintas» (all our distinct perceptions are distinct existences). Cf. HUME, A Treatise of Human Nature (1739-1740), Appendix; THN, vol. II, p. 319.

Ou, de acordo com outra formulação:

«Todos os seres no universo, considerados em si próprios, aparecem inteiramente soltos [loose] e independentes uns dos outros. É apenas por experiência que aprendemos a sua influência e conexão; e nunca devemos estender esta influência para além da experiência.» -- «All beings in the universe, considered in themselves, appear entirely loose and independent of each other. It is only by experience we learn their influence and connection; and this influence we ought never to extend beyond experience.», HUME, A Treatise of Human Nature, III, I, 1; THN, vol. II, p. 174.

91 «Die Empirie der Beobachtung allein kann nie die Nothwendigkeit genügend beweisen. Post hoc aber nicht propter hoc (Enc. I, 84). Dies ist so sehr richtig daß aus dem steten Aufgehn der Sonne des Morgens

\begin{tabular}{|l|l|l|l|l|}
\hline Qenista Dialectus & Ano 5 & n. 12 & Janeiro - Julho 2018 & p. 46-108 \\
\hline
\end{tabular}


A prática - de que «experimento» e «trabalho» constituem modalidades --, ao transformar materialmente, determina configurações novas do real, e, nessa medida, instaura, num solo ontológico, figuras acrescidas de um verdadeiro que objectivamente ela pro-duz.

Neste sentido, a «experiência» constata um facto, ou uma sucessão escandida de factos, na sua imediatez dada, mas não opera as transformações que, no decurso de um processo -- formando (ou re-modelando) uma materialidade objectiva --, confirmam a correcção de um pensamento, e traduzem o «poder» produtivo que ele é susceptível de nortear.

Aliás, e para tempestivo recordo de uma outra expressão muito glosada - ainda que nem sempre, porventura, nos termos mais adequados --, no que toca à «prova» do bolo (ou do chouriço): comer a iguaria não é propriamente o mesmo do que olhar para o $\operatorname{pudim}^{92} \ldots$

nicht folgt sie werde morgen wieder aufgehn, und in der That wissen wir jetzt daß ein Moment kommen wird wo die Sonne eines Morgens nicht aufgeht. Aber der Beweis der Nothwendigkeit liegt in der menschlichen Thätigkeit, im Experiment, in der Arbeit: Wenn ich das post hoc machen kann, wird es identisch mit dem propter hoc.», ENGELS, Dialektik der Natur, Dialektik der Wissenschaft, n. 150 (1877); $\mathrm{MEGA}^{2}$, vol. I/26, p. 373.

92 «A prova do pudim está no comer. A partir do momento em que pomos a uso nosso esses objectos, de acordo com as qualidades que percebemos neles, submetemos a um teste infalível a correcção, ou não, das nossas percepções dos sentidos.»-- «The proof of the pudding is in the eating. From the moment we turn to our own use these objects, according to the qualities we perceive in them, we put to an infallible test the correctness or otherwise of our senseperceptions.», ENGELS, Introduction to the English Edition (1892) of Socialism: Utopian and Scientific; CW, vol. 27, p. 287. idealizante:

Às vezes, o pitéu vem à mesa demolhado em caldas, decerto, bem-intencionadas, mas de sabor

«Este pudim é, porém, a constituição [die Konstituierung] do proletariado em classe: o tornar-sepraticamente-realidade da sua consciência de classe. O ponto de vista de que o proletariado é o sujeitoobjecto idêntico do processo histórico - quer dizer: o primeiro sujeito, no decurso da história, que é (objectivamente) capaz de uma consciência social adequada - aparece, assim, em figura mais concreta. A saber: mostra-se que a solução [die Lösung] objectivamente social das contradições, nas quais o antagonismo da mecânica do desenvolvimento se exterioriza, só é então praticamente possível quando esta solução aparece como novo estádio de consciência do proletariado, praticamente conquistado. A correcção, ou [a] falsidade, funcional da acção tem, portanto, o seu critério último no desenvolvimento da consciência de classe proletária.» -- «Dieser Pudding ist aber die Konstituierung des Proletariats zur Klasse: das Praktisch-zur-Wirklichkeit-Werden seines Klassenbewußtseins. Der Standpunkt, daß das Proletariat das identische Subjekt-Objekt des Geschichtsprozesses ist, d. h. das erste Subjekt im Laufe der Geschichte, das eines adäquaten gesellschaftlichen Bewußtseins (objektiv) fähig ist, erscheint damit in konkreterer Gestalt. Es erweist sich nämlich, daß die objektiv gesellschaftliche Lösung der Widersprüche, in denen sich der Antagonismus der Entwicklungsmechanik äußert, nur dann praktisch möglich ist, wenn diese Lösung als neue, praktisch errungene Bewußtseinsstufe des Proletariats erscheint. Die funktionelle Richtigkeit oder Falschheit der Handlung hat also ihr letztes Kriterium in der Entwicklung des proletarischen Klassenbewußtseins.», György LUKÁCS, Geschichte und Klassenbewußtsein. Studien über marxistische Dialektik (1923), Die Verdinglichung und das Bewußtsein des Proletariats, 6; Werke, Darmstadt-Neuwied, Hermann Luchterhand Verlag, $1972^{2}$, vol. II, pp. 386-387.

\begin{tabular}{|l|l|l|l|l|}
\hline Qenista Dialectus & Ano 5 & n. 12 & Janeiro - Julho 2018 & p. 46-108 \\
\hline
\end{tabular}


Adiante.

Nos Manuscritos de 1844, entretanto, abundam sinais quanto à maneira em que o caminho está a ser encontrado, e percorrido.

O eco feuerbachiano de algumas expressões utilizadas é por certo audível; mas ele tem que ser devidamente escutado, para que a proximidade dos acordes não abafe a linha melódica que em motivo condutor está a romper.

O eco não se limita a repercutir a fonte: passa a funcionar em contexturas, e a conhecer um desenvolvimento, em que o conteúdo e a orientação se firmam, e afirmam, num crescendo de diferenças.

«A solução dos enigmas teóricos é uma tarefa da prática, e [está] praticamente mediada» (die Lösung der theoretischen Räthsel eine Aufgabe der Praxis und praktisch vermittelt ist), não apenas porque a um tabuleiro vital ela seja devolvida, mas porque, na ponta de um movimento recursivo, «a verdadeira prática é a condição de uma teoria [efectivamente] real e positiva» (die wahre Praxis die Bedingung einer wirklichen und positiven Theorie ist).

Nestes termos, cabe ao «trabalho próprio do ser humano» (eigne Arbeit des Menschen) produzir «o sentido humano da Natureza, [e] portanto também», nessa base transformada, «o sentido natural do ser humano» (der menschliche Sinn der Natur, also auch der natürliche Sinn des Menschen $)^{93}$.

E a industriosidade invocada não se acantona no simples engenho imaginativo.

A metáfora do fabrico - inclusivamente, não esquecendo as «alienações» que lhe determinam a forma, e lhe povoam o quotidiano de misérias - torna-se um emblema do constitutivo trabalho ontológico das realidades pelos humanos.

A robustez de um proletariado -- detentor de uma consciência de classe correcta, e organizado combativamente -- não é de todo indiferente ao travar, e ao desfecho, das lutas. Mas daí não se segue, sem entorses algo graves, nem que a «consciência» (mesmo que «justa») seja o critério da verdade, nem que a unidade material do real se subsuma num «sujeito-objecto» (mesmo que historicamente qualificado) das representações.

93 Cf. MARX, Ökonomisch-philosophische Manuskripte (1844), Heft III, Zusätze; MEGA², vol. I/2, p. 424.

\begin{tabular}{|l|l|l|l|l|}
\hline Qenista Qialectus & Ano 5 & n. 12 & Janeiro - Julho 2018 & p. 46-108 \\
\hline
\end{tabular}


Tal como Feuerbach reclamava, o saber tem que reatar as interrompidas relações com a Natureza ${ }^{94}$, mas - e nesta direcção começa Marx a fazer inflectir o escavamento historicamente aprofundado dos sítios - essa naturalidade da implantação mundana das colectividades humanas encontra-se pelo seu labor próprio mediada:

«A indústria é a relação histórica [efectivamente] real da Natureza - e, daí, da ciência da Natureza - ao ser humano» ${ }^{95}$.

O ser -- do qual se busca uma compreensão científica -- não está apenas defronte como ex-orbitante «alteridade» intocada ${ }^{96}$. Integra, e com-porta, enquanto ingrediência material objectiva, um viver histórica e socialmente entretecido de transformações:

«Uma base diferente [eine andre Basis] para a vida, [e] uma outra [base] para a ciência, é, desde o início, uma mentira [eine Lüge]. A Natureza que devém na história humana - no acto de engendramento [Entstehungsakt] da sociedade humana - é a Natureza [efectivamente] real do ser humano, pelo que a Natureza tal como ela devém pela indústria (ainda que em figura alienada) é a verdadeira Natureza antropológica.» ${ }^{97}$.

94 «A filosofia tem que se aliar de novo à ciência da Natureza, [e] a ciência da Natureza à filosofia. Esta aliança [Verbindung] - fundada numa precisão recíproca [gegenseitiges Bedürfnis], numa necessidade interna - será mais duradoura, mais feliz, e mais frutuosa, do que o até agora mau-casamento [die bisherige Mesalliance] entre a filosofia e [a] teologia.» -- «Die Philosophie mu $\beta$ sich wieder mit der Naturwissenschaft, die Naturwissenschaft mit der Philosophie verbinden. Diese auf gegenseitiges Bedürfnis, auf innere Notwendigkeit gegründete Verbindung wird dauerhafter, glücklicher und fruchtbarer sein als die bisherige Mesalliance zwischen der Philosophie und Theologie.», FEUERBACH, Vorläufige Thesen zur Reformation der Philosophie (1843); GW, vol. 9, p. 262.

Acerca do contrastivo modo hegeliano de perspectivar esta mesma questão -- sobre um fundo onde as críticas do empirismo superficial, e, sobretudo, da formalidade imaginosa de Schelling na sua Naturphilosophie, têm garantido domicílio persistente --, veja-se, por exemplo: HEGEL, Enzyklopädie der philosophischen Wissenschaften im Grundrisse (1830), II, Einleitung; TW, vol. 9, pp. 9-11.

95 «Die Industrie ist das wirkliche geschichtliche Verhältniß der Natur und daher der Naturwissenschaft zum Menschen», MARX, Ökonomisch-philosophische Manuskripte (1844), Heft III, Ergänzungen zu Heft II, Privateigentum und Kommunismus; MEGA², vol. I/2, p. 396.

96 É neste sentido -- animado já por uma demarcação em crescimento, relativamente às «recuperações pensantes» de índole hegelianista, em que tudo acaba, e começa, por estar absorvido numa consciência omni-abarcante - que Feuerbach, em 1839, numa carta a Arnold Ruge, proclama:

«O ^ $\vartheta \gamma \Delta \cong<$ [o outro] é o princípio da vida: [e] o princípio da vida [é] o princípio do pensar.» -«as ^ $\vartheta \gamma \Delta \cong<$ ist das Prinzip des Lebens - d[as] Prinzip des Lebens das Prinzip des Denkens.», FEUERBACH, Brief an Arnold Ruge, 8./14. Mai 1839; GW, vol. 17, p. 364.

97 «Eine andre Basis für das Leben, eine andre für die Wissenschaft, ist von vornherein eine Lüge. Die in der menschlichen Geschichte - dem Entstehungsakt der menschlichen Gesellschaft werdende Natur - ist die wirkliche Natur des Menschen, darum die Natur, wie sie durch die Industrie, wenn auch in entfremdeter Gestalt wird, die wahre anthropologische Natur ist.», MARX, Ökonomisch-philosophische Manuskripte (1844), Heft III, Ergänzungen zu Heft II, Privateigentum und Kommunismus; MEGA ${ }^{2}$, vol. I/2, p. 396.

\begin{tabular}{|l|l|l|l|l|}
\hline Qevista Dialectus & Ano 5 & n. 12 & Janeiro - Julho 2018 & p. 46-108 \\
\hline
\end{tabular}




\section{§ 7. Implantação prática do pensar.}

A «citerioridade» do pensar não se reporta somente à condição mundana dos objectos sobre os quais ele se debruça (o que, em rigor, já não seria pouco ${ }^{98}$ ), e que

98 Com efeito, a «citerioridade» -- em vários estiradores idealistas redesenhada - procurava refúgio nas muralhas de um outro recinto: a consciência auto-substante.

A estridente campaínha de alarne fora acccionada no aquartelamento por Gottlob Ernst Schulze, logo em 1792. O idealismo «crítico» de Kant enfermava afinal de uma «dogmatista» incongruência sem remédio, uma vez que, apesar das solenes proibições ao tráfico decretadas, sempre persistia em admitir um «além» da representação:

«A despeito de, porém, a crítica da razão [pelo kantismo levada a cabo] afirmar que um conhecimento das coisas em si em nós seria impossível, segundo ela, contudo, o agregado todo [der ganze Inbegriff] das representações humanas de modo nenhum é meramente uma aparência vazia [ein leerer Schein] que não se referisse realmente [realiter] a nada, fora elas próprias. A saber: segundo ela, todo o nosso conhecimento começa com a experiência, e existem realmente objectos fora de nós que afectam os nossos sentidos» -- «Ohnegeachtet aber die Vernunftkritik behauptet, daß eine Erkenntniß der Dinge an sich in uns unmöglich sey, so ist doch nach ihr der ganze Inbegriff der menschlichen Vorstellungen keineswegs bloß ein leerer Schein, der sich auf gar nichts außer denselben realiter bezöge. Alle unsere Erkenntniß fängt nämlich nach ihr mit der Erfahrung an, und es sind Gegenstände außer uns wirklich da, welche unsere Sinne afficieren», Gottlob Ernst SCHULZE, Aenesidemus oder über die Fundamente der von dem Herrn Professor Reinhold in Jena gelieferten Elementar-Philosophie (1792), Apologie des Skepticismus gegen die Anhänger der Vernunftkritik; ed. Arthur Liebert, Berlin, Verlag von Reuther \& Reichard, 1911, p. 196. Fichte.

A resposta, em vários episódios proporcionada, veio a lume com o idealismo correctivo de

«O Não-Eu» (das Nicht-Ich) ao qual o sujeito representativamente se reporta «não é percepcionado, mas originariamente posto» -- «nicht wahrgenommen, sondern ursprünglich gesetzt wird» -- no próprio Eu, por uma acção instituinte deste. Cf. FICHTE, Recension des Aenesidemus oder über die Fundamente der vom Herrn Professor Reinhold in Jena gelieferten Elementar-Philosophie (1792); W, vol. I, p. 9.

Em conformidade, deixa de haver lugar para quaisquer resíduos irredutíveis com pretensões de transcendência, dado que a «exterioridade» é sempre «posta» em mim, e por mim:

«Eu só me percepciono a mim próprio; pura e simplesmente, [só percepciono] o meu estado [Zustand] próprio, mas não o objecto; [...] eu sinto o meu sentir. Ora, por esse facto, de modo nenhum se me engendra um qualquer conhecimento de um ser, mas apenas o sentimento do meu estado próprio.»--«ich nur mich selbst, meinen eigenen Zustand schlechthin, aber nicht den Gegenstand wahrnehme; [...] ich empfinde mein Empfinden. Dadurch entsetht mir nun keineswegs irgend eine Erkenntniss eines Seyns, sondern nur das Gefühl meines eigenen Zustandes.», FICHTE, Die Bestimmung des Menschen (1800), II; W, vol. II, respectivamente, pp. 211 e 229-230.

Encontramos uma matriz de «solução» aparentada - ainda que sem o apoio nesta teoria fichteana do Eu - no «empiriocriticismo» de Ernst Mach:

«A coisa, o corpo, a matéria, não são nada fora da conexão dos elementos, das cores, [dos] sons, etc., [nada] fora das chamadas características [Merkmale]. [...]. Os corpos não engendram sensações, mas complexos de elementos (complexos de sensações) [é que] formam os corpos.»-- «Das Ding, der Körper, die Materie ist nichts außer dem Zusammenhang der Elemente, der Farben, Tönen u. s. w. außer den sogenannten Merkmalen. [...]. Nicht die Körper erzeugen Empfindungen, sondern Elementenkomplexe (Empfindungskomplexe) bilden die Körper.», Ernst MACH, Die Analyse der Empfindungen und das Verhältnis des Physischen zum Psychischen (1883, 1922'), I, 3 e 13; ed. Gereon Wolters, Darmstadt, Wissenschaftliche Buchgesellschaft, 1991, respectivamente, pp. 5 e 23.

\begin{tabular}{|l|l|l|l|l|}
\hline Qevista Dialectus & Ano 5 & n. 12 & Janeiro - Julho 2018 & p. 46-108 \\
\hline
\end{tabular}


permite, «na prática» (in der Praxis), aferir da «realidade [efectiva]» (Wirklichkeit) - ou seja, da correcção com uma contrapartida real -- dos produtos teoréticos resultantes das suas elaborações.

Qualquer «querela» (Streit) que gire em torno da «comensurabilidade» do ser e da consciência, bem como do alcance cognitivo que lhe assista -- segundo modalidades, graus, e métodos procedimentais, diversos e investigandos -, não pode prescindir de um suposto basilar:

Na sua génese, no seu exercício, nas derivas que abre e proporciona, o pensarpor mais que a variegadas figuras de um «além» seja susceptível de nos transportar (em arrebatados transes místicos de fuga, em irrequietos dispositivos compensatórios pela ânsia do desejo pungidos, em transgressões esteticamente ficcionadas do existente, em sondagens daquele leque de possíveis que cada existência adiante de si pro-jecta, etc.) dispõe como território de implantação: o «aquém».

Pensamos o real, de dentro do real, e no horizonte de uma actividade que no seio das realidades desenvolvemos.

Mas o pensamento - com toda a sua especificidade (que de modo nenhum há que rasurar para emenda, desmerecer por desconfiança, pospor até à vinda de melhores dias, ou suprimir sem mais explicações) - constitui ele próprio uma função real, o quer dizer: materialmente enraizada, e no seu devir histórico situada.

O pensar não pode, por conseguinte, ser airosamente des-ligado da prática, e transferido pra uma redoma de levitações etéreas, porque se encontra montado sobre um viver que é ele próprio constitutivamente prático.

A plataforma para o enfoque dialéctico destas matérias alcança os contornos, e a estrutura marcante, nas Teses. Em A ideologia alemã, ela virá a receber uma expressão condensada, que lhe reflecte, não obstante, a fundmentalidade dos traços:

As discussões, no tempo de Lénine, recrudesciam num ambiente marcado por estas cambiantes idealistas, das quais muitos alegados adeptos do «marxismo» se não davam conta.

Daí a chamada de atenção para o indescartável embasamento materialista que neste apontamento segundo Marx assinala, e o aviso dirigido a todos aqueles que se apressam a «saltar por cima logo da primeira frase da tese, sem pensar que a "verdade objectiva" (gegenständliche Wahrheit) do pensamento não significa outra coisa senão a existência dos objectos (= "coisas em si") reflectidos verdadeiramente pelo pensamento». Cf. LÉNINE, Materialismo e Empiriocriticismo (1909), II, 1; ME, p. 79.

\begin{tabular}{|l|l|l|l|l|}
\hline Q Ronista Dialectus & Ano 5 & n. 12 & Janeiro - Julho 2018 & p. 46-108 \\
\hline
\end{tabular}


«A consciência [das Bewußtsein] nunca pode ser outra coisa [etwas Andres] senão o ser consciente [das bewußte Sein], e o ser [das Sein] dos seres humanos é o seu processo [efectivamente] real de vida [wirklicher Lebensprozeß].» ${ }^{99}$.

Para que as «ideias» possam ser submetidas ao criterioso exame crítico que não dispensam (e, em todo o caso, requerem), importa precaver-se contra a desenvoltura do seu despacho sumário para uma nuvem sobrepairante.

E é aqui que entronca a advertência expressa na parte final deste apontamento.

§ 8. $O$ «divórcio»e a «escolástica».

As versões conhecidas mostram uma discrepância ligeira.

Marx reporta-se à vanidade de um pensar «que está isolado da prática» (das von der Praxis isoliert ist), Engels «lê», ou redige: de um pensar «que se isola da prática» (das sich von der Praxis isoliert).

Pondo de parte eventuais questões de elegância formal no dizer, ou de decifração do manuscrito, as duas formulações enunciam o mesmo, e, na dinâmica do real que em momentos diferenciados reflectem, completam-se.

Marx acentua o «estado» resultante de uma determinada acção de isolamento, enquanto Engels coloca, por sua vez, o foco na dimensão activa perdurante através da qual esse apartamento se processa.

Um pensamento que «esteja isolado» da prática carece -- à partida dos percursos, e como decorrência das vulnerabilidades no socalco consentidas -- daquele mordente vital susceptível de alimentar aspirações (material e concretamente, fundadas) a uma «realidade efectiva» para os ideatos que confecciona.

Um pensamento que se isola da prática carrega prognósticos de desembocadura em becos igualmente sem saída, em virtude da incursão num vício de idêntico recorte, sendo que o «isolacionismo» compulsivo de que -- deliberadamente, ou não -- enferma

\footnotetext{
99 «Das Bewußtsein kann nie etwas Andres sein als das bewußte Sein, und das Sein der Menschen ist ihr wirklicher Lebensprozeß.», MARX-ENGELS, Die deutsche Ideologie (1845-1846), I, A; MEW, vol. 3, p. 26.
}

\begin{tabular}{|l|l|l|l|l|}
\hline Ronista Dialectus & Ano 5 & n. 12 & Janeiro - Julho 2018 & p. 46-108 \\
\hline
\end{tabular}


requer também entendimento quanto às razões práticas, materiais, que o sustentam e conduzem.

Com efeito, não é porque uma dada doutrina se define como eximindo-se ao seu condicionalismo material e histórico que ela efectivamente dele se encontra livre. Muito pelo contrário. Nas pulsões nefelibatas com uso largamente documentado na redondeza avulsa, a pedestre rampa de lançamento aos céus pode ficar escondida entre seráficos vapores, mas não se desvanece por milagre ${ }^{100}$.

E, por conseguinte, na vertente crítica, importa não apenas censurar o constatado divórcio relativamente à prática, que confere teor determinado às ideações nas quais se espelha (e espalha). Impõe-se, de igual modo, a investigação e o estudo das condições, e dos processos, que permitem compreender a recorrente tomada desses gazeificados caminhos.

Discutir acerca da realidade efectiva de um pensar que se entregue à cogitância nesta suposta redoma de isolamento depurado é «uma questão puramente escolástica» (eine rein scholastische Frage).

Não é a discussão que é vã; é o pensamento que estaria vanificado.

O porquê da peremptória afirmação acabou de ser explicitado:

A realidade efectiva mede-se pela materialidade do real, e não pela ideialidade objectual dos ideatos na consciência.

Por outro lado, não há pensar - por mais subtil que se imagine -- que não esteja humanamente montado sobre a prática constitutiva de um viver, o que não lhe assegura uma fidedignidade «mecânica» no produto, mas obriga a uma cuidada atenção ao exame crítico na desmontagem dos «mecanismos».

\footnotetext{
${ }^{100}$ Como num dos artigos para os Deutsch-Französische Jahrbücher se lê, «uma consciência invertida do mundo» (ein verkehrtes Weltbewußtsein) é, muitas vezes, a forma de representação correspondente a «um mundo invertido» (eine verkehrte Welt).

Reconhecendo os contributos de Feuerbach na tempestiva denúncia, Marx, dando-lhe um passo à frente, havia entretanto alcançado já a inflexão necessária a imprimir aos combates:

«A religião [...] é a realização fantástica [die phantastische Verwirklichung] da essência humana, porque [no mundo invertido] a essência humana não possui nenhuma verdadeira realidade [efectiva]. A luta contra a religião é portanto, mediatamente [mittelbar], a luta contra aquele mundo, de que a religião é [o] aroma espiritual.» -- «Die Religion [...] ist die phantastische Verwirklichung des menschlichen Wesens, weil das menschliche Wesen keine wahre Wirklichkeit besitzt. Der Kampf gegen die Religion ist also mittelbar der Kampf gegen jene Welt, deren geistiges Aroma die Religion ist.», MARX, Zur Kritik der Hegelschen Rechtsphilosophie. Einleitung (1844); MEGA², vol. I/2, p. 170.
}

\begin{tabular}{|l|l|l|l|l|}
\hline Qevista Dialectus & Ano 5 & n. 12 & Janeiro - Julho 2018 & p. 46-108 \\
\hline
\end{tabular}


Falta, no entanto, deitar uma espreitadela à adjectivação empregue: qualifica um comportamento dito «escolástico».

A referência imediata remete-nos para medievos certames (todavia, com edição conhecida em formatos ulteriores: institucionalmente transformados, mas nem sempre corrigidos na substância e no artifício).

As disputationes eram, de facto, um método amiúde utilizado pela Escolástica medieval $^{101}$. Como forma requintada de tratamento solene das matérias pelos doutores (a par da lectio tradicional de púlpito), e como exercício escolar de treino em ginástica argumentativa no trazer-por-casa dos colégios.

Havia carga dialéctica no porão, porque a quaestio que desencadeava o prélio vinha acompanhada de altos patrocínios (sacros, e profanos) em contradita, o que, pelas dúvidas suscitadas e a perplexidade nutrida, sempre impunha algum cuidado na escolha dos oradores e na selecção dos auditórios ${ }^{102}$.

No entanto, com usitada frequência, o peso resolutivo das contendas obtinha-se pelo despejo na balança de um elenco massudo de distinctiones conceptuais de capela, cujo fundamento in rebus, era muito rarefeito, quedando-se o efeito pela prestidigitação hábil de uns floreados lúdico-formais de flamejância variável.

Da má-fama - não raro, merecida -- deste escolasticismo questiuncular não se desenvencilharam também outras modalidades e brotoejos serôdios de cultura, soturna ou levemente, escolarizada.

Com poiso oficialista em circunspectas agremiações académicas de vário brilho, mas também com nicho esparso pela doutrinação tertuliar de recorte -- segundo a autopropaganda -- «avançado».

101 Para enquadramentos sucintos, vejam-se, por exemplo: Étienne GILSON, La Philosophie au Moyen $\hat{A} g e$, des origines patristiques à la fin du XIV siècle, VII, 2; Paris, Payot, $1962^{2}$, pp. 398-399, e Gian Carlo GARFAGNINI, «Dialettica, etica e politica tra XII e XIV secolo», Dialettica. Tradizioni, problemi, sviluppi, ed. Alberto Burgio, Macerata, Quodlibet, 2007, pp. 51-73.

${ }^{102}$ Um experimentado disputador deixou-nos, aliás, algumas recomendações elucidativas, quanto a «se é de disputar em público com os infiéis» (utrum sit cum infidelibus publice disputandum):

«Da parte dos auditores, é, na verdade, de considerar se aqueles que ouvem a disputa são instruídos, e firmes na fé, ou se são simples, e titubeantes na fé. [...]. No segundo caso, é, na verdade, perigoso disputar em público acerca da fé perante os simples, pelo facto de que a fé deles é mais firme por não terem ouvido nada de diverso daquilo que acreditam.» -- «Ex parte vero audientium considerandum est utrum illi qui disputationem audiunt sint instructi et firmi in fide, aut simplices et in fide titubantes. [...]. In secundo vero casu pericolosum est publice disputare de fide coram simplicibus; quorum fides ex hoc est firmior quod nihil diversum audierunt ab eo quod credunt.», TOMÁS DE AQUINO, Summa Theologiae, $\mathrm{II}^{\mathrm{ae}}-\mathrm{II}^{\mathrm{ae}}$, q. 10, a. 7 .

\begin{tabular}{|l|l|l|l|l|}
\hline Qevista Dialectus & Ano 5 & n. 12 & Janeiro - Julho 2018 & p. 46-108 \\
\hline
\end{tabular}


O convencido desprezo destilado pela «Crítica crítica» de Bruno Bauer contra «a massa» (die Masse $)^{103}$ - boçal inimiga da «teoria» (Theorie), do «espírito» (Geist), da sempre criativa «auto-consciência» (Selbstbewußtsein) - fora certeiramente zurzido por Marx e por Engels, desde A sagrada família ${ }^{104}$.

No entanto, não se me afigura que o epíteto «escolástico», nesta passagem das Teses, se prenda directamente com este contencioso, em que a clarividência intelectual

103 Fruto deiscente da Revolução Francesa, com incarnação candente no proletariado:

«A massa, como tal, é um fenómeno que somente podia ocorrer [eintreten], depois de as diferenças específicas em que o género [humano, Gattung] até agora se havia exposto terem expirado. Ela é o decaimento [der Verfall] do género na mole [Menge] dos átomos singulares, a dissolução das barreiras particulares que decerto até agora separavam os indivíduos, mas que também os vinculavam, e punham numa ligação multiforme; ela é um material [ein Stoff] meramente elementar, o sedimento de uma figura orgânica decomposta.» -- «Die Masse als solche ist eine Erscheinung, die erst eintreten konnte, nachdem die spezifischen Unterschiede, in welchen sich die Gattung bisher dargestellt hatte, erblaßt waren. Sie ist der Verfall der Gattung in die Menge der einzelnen Atome, die Auflösung der besonderen Schranken, welche die Individuen bisher zwar trennten, aber auch verbanden und in eine mannigfaltige Beziehung setzten; sie ist ein bloß elementarischer Stoff, der Niederschlag einer zersetzten organischen Gestalt.», Bruno BAUER, Die Gattung und die Masse (1844); Feldzüge der reinen Kritik, ed. Hans-Martin Saß (doravante: FrK), Frankfurt am Main, Suhrkamp Verlag, 1968, p. 215.

Mesmo sem intertextualidades confirmadas, o tema continua a dispôr de alarmados cultores, só na aparência, desencontrados.

Tönnies, que mostra conhecer o contexto, na tipologia conceitual que estabelece, contrapõe «a comunidade» (die Gemeinschaft), entendida como «um organismo vivo» (ein lebendiger Organismus), à «sociedade»(Gesellschaft), que não passaria de «um mecânico agregado e artefacto» (ein mechanisches Aggregat und Artefakt), «um mero conglomerado de pessoas independentes umas das outras» (ein bloßes Nebemeinander voneinander unabhängiger Personen). Cf. Ferdinand TÖNNIES, Gemeinschaft und Gesellschaft. Grundbegriffe der reinen Soziologie (1887, 1935 ${ }^{8}$ ), I, § 1; Darmstadt, Wissenschaftliche Buchgesellschaft, 1991, p. 4.

Para Ortega (ainda a sofrer de alguns problemas digestivos com a Revolução de Outubro), em oposição às «minorias» -- «indivíduos, ou grupos de indivíduos, especialmente qualificados» (individuos o grupos de individuos especialmente calificados) --, a massa é «a multidaão» (la muchedumbre), «o mostrengo social» (lo mostrenco social), «o homem enquanto não se diferencia de outros homens, mas repete em si un tipo genérico» (el hombre en cuanto no se diferencia de otros hombres, sino que repite en sí un tipo genérico). Cf. José ORTEGA Y GASSET, La rebelión de las masas (1929), I, I; Madrid, Revista de Occidente, $1963^{37}$, p. 52.

Em tempos mais chegados, a restauração torna ao palco, mas numa montagem reencenada e com guarda-roupa «alternativo». A velha desconfiança - tremente, porque tremenda -- mantém-se: «A essência das massas é indiferença: todas as diferenças estão submergidas e afogadas nas massas.» -- «The essence of the masses is indifference: all differences are submerged und drowned in the masses.». Portanto, nas inamovidas (e inamovíveis) condições económicas do «Império» (Empire), o novo sujeito da «acção politica» (political action) há-de ser «a multidão» (the multitude) das «singularidades» (singularities) inunificáveis, mas na pluralidade escandida comunicantes nas redes, até porque, muito democraticamente, «na multidão, as diferenças sociais permanecem diferentes» (in the multitude, social differences remain different). Cf. Michael HARDT e Antonio NEGRI, Multitude. War and Democracy in the Age of Empire (2004), Preface, e 2; London, Penguin Books, 2005, respectivamente, pp. XIV-XV e 99-102.

${ }^{104}$ Cf. ENGELS-MARX, Die heilige Familie (1845), VII; MEW, vol. 2, pp. 152-171.

\begin{tabular}{|c|c|c|c|c|}
\hline Qovista Dialectus & Ano 5 & n. 12 & Janeiro - Julho 2018 & p. $46-108$ \\
\hline
\end{tabular}


dos iluminados é contraposta ao amorfismo indigente das «massas» proletárias -- para cúmulo da desdita - com «instintivos» sentimentos comunistas ${ }^{105}$.

Penso, em contrapartida, que é possível descortinar um contexto feuerbachiano para a escolha do termo, em que à proximidade vem igualmente associado um relevante sinal de demarcação.

Para Feuerbach, incorre em imperdoável vício «escolástico» toda aquela atitude filosófica que não se atenha à imediatez do dado por uma certeza sensível verificado ${ }^{106}$, e que, sobremaneira, ao jeito de Hegel, insista no papel desempenhado pela «mediação» (Vermittlung) no processual apuramento de uma verdade concreta (com uma totalidade de determinações em devir no seu seio) ${ }^{107}$.

105 Assinale-se, em contraponto, que muitos comentadores -- embora sem referência a Bruno Bauer aproveitam esta passagem para invocar um enquadramento diferente.

Por exemplo, Gramsci - entendendo por «actividade prática» (attività pratica), sintomaticamente a meu ver, «uma vontade activa, transformadora do mundo» (una volontà attiva, trasformatrice del mondo) - aproxima este passo da função que ao proletariado cabe desempenhar.

Depois de referir que «o "conhecimento" só na actividade prática é "conhecimento real", e não "escolasticismo"» (la "conoscenza" solo nell'attività pratica è "reale conoscenza" e non "scolasticismo"), prossegue:

«Deduz-se também daqui que o carácter da filosofia da práxis é especialmente aquele de ser uma concepção de massa, uma cultura de massa, e de massa que opera unitariamente, isto é, que tem normas de conduta não apenas universais na ideia, mas "generalizadas" na realidade social. E a actividade do filósofo "individual" não pode ser concebida, portanto, senão em função dessa unidade social, isto é, [não poder ser concebida senão] também ela como política, como função de direcção política.» -- «Se ne deduce anche che il carattere della filosofia della praxis è specialmente quello di essere una concezione di massa, una cultura di massa e di massa che opera unitariamente, cioè che ha norme di condotta non solo universali in idea, ma "generalizzate" nella realtà sociale. E l'attività del filosofo "individuale" non può essere pertanto concepita che in funzione di tale unità sociale, cioè anch'essa come politica, come funzione di direzione politica.», GRAMSCI, Quaderni del carcere, Quaderno 10 (1932-1935), § 31; Q, vol. II, p. 1271.

106 «A filosofia tem, por conseguinte, que começar, não consigo, mas com a sua antítese, com a nãofilosofia. Este ser [Wesen] -- diferente do pensar, não-filosófico, absolutamente anti-escolástico -- é, em nós [in uns], o princípio do sensualismo.» -- «Die Philosophie hat daher nicht mit sich, sondern mit ihrer Antithese, mit der Nichtphilosophie, zu beginnen. Dieses vom Denken unterschiedene, unphilosophische, absolut antischolastische Wesen in uns ist das Prinzip des Sensualismus.», FEUERBACH, Vorläufige Thesen zur Reformation der Philosophie (1843); GW, vol. 9, p. 254.

107 «"Tudo está mediado”, diz a filosofia de Hegel. Mas, algo só é verdadeiro [wahr], se não fôr mais um mediado [ein Vermitteltes], mas [algo de] imediato [Unmittelbares]. As épocas históricas só surgem, por isso, lá onde aquilo que, anteriormente, era apenas um pensado [ein Gedachtes], [algo de] mediado, se torna objecto de certeza imediata [unmittelbare Gewißheit], [de certeza] sensível [sinnliche Gewißheit]: [lá onde] se torna, por isso, verdade aquilo que, anteriormente, era apenas pensamento [Gedanke]. Escolástica é [sim] fazer da mediação uma necessidade divina, e propriedade essencial [wesentliche Eigenschaft] da verdade.»-- "“Alles ist vermittelt”, sagt die Hegelsche Philosophie. Aber wahr ist etwas nur, wenn es nicht mehr ein Vermitteltes, sondern Unmittelbares ist. Geschichtliche Epochen entestehen darum nur da, wo, was früher nur ein Gedachtes, Vermitteltes war, Objekt unmittelbarer, sinnlicher Gewißheit - Wahrheit darum wird, was früher nur Gedanke war. Scholastik ist es, die Vermittlung zu

\begin{tabular}{|l|l|l|l|l|}
\hline Q Rovista Dialectus & Ano 5 & n. 12 & Janeiro - Julho 2018 & p. 46-108 \\
\hline
\end{tabular}


O materialismo de Feuerbach - confessadamente, e logo desde a entrada -- está dirigido contra a hegeliana primazia atribuída a um «pensar» (Denken) que tudo começa por dissolver em «pensamento»(Gedanken), e, por tabela (junto com incompreensões de outra ordem), procede a um despejo sumário da dialéctica.

Para Marx, uma questão torna-se «escolástica», certamente, quando a própria materialidade do ser é desatendida. Só que esta materialidade não se reconhece por uma troca da consciência «pensante» pelos protocolos de uma consciência «sentinte», nem deita para o caixote das divinas especulações a mediação histórica inscrita no corpo das realidades, da qual a prática transformadora é constitutiva componente endógena.

Uma vez mais, e como a cada cavadela do chão à estrada salta: o materialismo dialéctico de Marx não se identifica com o sensualismo materialista de Feuerbach.

Infelizmente, continua a haver quem na diferença não repare.

\section{§9. A «realização».}

A rematar o comentário desta tese 2 , convém também não esquecer uma outra peça que pela engrenagem dos aparelhos filosófico-político-culturais da altura, e nestes ambientes, igualmente andava solta, e em desencontrados solavancos.

Para Marx, qualquer questionamento sério acerca da realidade efectiva do pensar começa por exigir uma colocação materialista dialéctica do próprio problema em bases onto-gnosiológicas sólidas, que permitam uma lida eficaz com ele, inclusivamente, no tocante à miudeza dos seus meandros.

einer göttlichen Notwendigkeit und wesentlicher Eigenschaft der Wahrheit zu machen.», FEUERBACH, Grundsätze der Philosophie der Zukunft (1843), § 39; GW, vol. 9, p. 321.

Feuerbach «quer» o materialismo, mas não entende a dialéctica.

Curiosamente, acerca da «filosofia escolástica» (scholastische Philosophie), Hegel, entre outras coisas, tinha lembrado o seguinte:

«Ela deixa a realidade [efectiva] totalmente ao lado de si como o desprezado [das Verachtete], não tinha nenhum interesse por ela. Pois a razão encontrava para si a sua realização, [a sua] existência, num outro mundo, não neste mundo; e toda a marcha para diante da civilização [der ganze Fortgang der Kultur] vai, depois disso, [no sentido] de restabelecer a crença neste mundo.» -- «Sie läßt die Wirklichkeit ganz neben sich liegen als das Verachtete, sie hatte keine Interesse für sie. Denn die Vernunft fand sich ihre Verwirklichung, Dasein in einer anderen Welt, nicht in dieser Welt; und der ganze Fortgang der Kultur geht darauf, den Glauben an diese Welt wiederherzustellen.», HEGEL, Vorlesungen über die Geschichte der Philosophie (1833-1836), II, II, A; TW, vol. 19, p. 544.

\begin{tabular}{|c|c|c|c|c|}
\hline Qonista Dialectus & Ano 5 & n. 12 & Janeiro - Julho 2018 & p. $46-108$ \\
\hline
\end{tabular}


Sob diversos ângulos, as Teses -- mesmo naquele seu telegrafismo em poupança de explicitações (decorrente de a escrita não possuir ainda o formato da publicidade) conferem assento à perspectiva que importa desenvolver.

No entanto, a querela dispunha, ao tempo, de uma moldura bastante preenchida por diferentes bosquejos de uma obra anunciada (mas ainda por vir), que lhes definia o imediato telão de fundo, e que, da mesma sorte, lhes perfilava um prospectivo horizonte de respiração.

O caixilho -- tornado questão histórica, a nas vicissitudes do momento assumir, e a na pauta do dia, como ponto de ordem nas preocupações, inscrever - tinha, na glosa, por obrigatório mote: a «realização da razão» ${ }^{108}$.

Em rigor, a encomenda fazia parte integrante já do legado hegeliano, ainda em vida, testamentariamente disposto.

Consignava o destino escatológico da Modernidade, inscrito na própria odisseia - uma «teodiceia» ${ }^{109}$-- do Espírito em curso de deveniente feitura no mundo:

«O movimento [die Bewegung] de, [a partir] de si [von sich], tirar para fora [hervortreiben] a forma do seu saber é o trabalho [die Arbeit] que ele [o Espírito] leva a cabo [vollbringen] como história [efectivamente] real.» ${ }^{110}$.

${ }^{108}$ Para outros desenvolvimentos em torno desta problemática, veja-se, designadamente, o meu livro: A «realização da razão». Um programa hegeliano?, Lisboa, Editorial Caminho, 1990.

109 O designativo fora cunhado por Leibniz como emblema para uma justificação racional das maldades empiricamente constatadas, à luz de um superior desígnio de harmonia pré-ordenada.

Neste sentido, haverá a «Teodiceia» (Theodicea) que ser entendida como a «doutrina da justiça (isto é, da sabedoria e, simultaneamente, da bondade) de Deus» -- «doctrina de justitia (id est sapientia simul et bonitate) Dei», Gottfried Wilhelm LEIBNIZ, Brief an Bartholomaeus des Bosses, 5. Februar 1712; Die philosophischen Schriften, ed. Carl Immanuel Gerhardt, reprod. Hildesheim, Georg Olms Verlagsbuchhandlung, 1965, vol. II, p. 437.

Hegel, para a sua visão filosoficamente compreensiva do acontecer histórico, não enjeita nem o termo nem a linhagem, mas dialectiza-lhe os conteúdos:

«A nossa consideração é, nesta medida uma teodiceia [eine Theodizee], uma justificação [eine Rechtfertigung] de deus, que Leibniz ensaiou metafisicamente à sua maneira em categorias abstractas, ainda indeterminadas, de tal modo que o mal [das Übel] no mundo havia de ser concebido, [ou seja:] o espírito pensante [der denkende Geist] [havia de ser] reconciliado com o mal [mit dem Bösen versöhnt].» -- «Unsere Betrachtung ist insofern eine Theodizee, eine Rechtfertigung Gottes, welche Leibniz metaphysisch auf seine Weise in noch unbestimmten, abstrakten Kategorien versucht hat, so daß das Übel in der Welt begriffen, der denkende Geist mit dem Bösen versöhnt werden sollte.», HEGEL, Vorlesungen über die Philosophie der Geschichte (1837, 1840²), Einleitung, A; TW, vol. 12, p. 28.

110 «Die Bewegung, die Form seines Wissens von sich hervorzutreiben, ist ide Arbeit, die er als wirkliche Geschichte vollbringt.», HEGEL, Phänomenologie des Geistes (1807), VIII; TW, vol. 3, p. 586.

\begin{tabular}{|l|l|l|l|l|}
\hline Qevista Wialectus & Ano 5 & n. 12 & Janeiro - Julho 2018 & p. 46-108 \\
\hline
\end{tabular}


E, neste transe -- em que algo, que meramente é «em si» (an sich), precisa de se objectivar para que possa vir a saber-se --, a dicotomia, não mais intransponível, de um «além»e do «aquém» volta a ser chamada ao palco.

Na Idade Média, como Hegel refere, a palavra prevalecente do Espírito - ainda sobre si mesmo dobrado - colocava essa «interioridade» não desenvolvida num celestial domicílio no «Além»:

«O meu reino não é deste mundo» (Mein Reich ist nicht von dieser Welt $)^{111}$.

Esta localização, porém, a despeito da distopia, não corresponde propriamente a uma sepultura monumental em jazigo perpétuo.

No eixo da temporalidade, cabe aos Tempos Modernos a tarefa de providenciar a exigida - e exigente - mudança de residência: os tarecos e a casa precisam de ser transportados das lonjuras do estrangeiro, para a doméstica vizinhança do bairro.

Em esboço rudimentar pela religião representada, e na figura do «conceito» pela filosofia desenvolvida, «a Ideia tem que se realizar na realidade [efectiva]» (die Idee mu $\beta$ sich realisieren in der Wirklichkeit), através de umas obras públicas de construção civil de «um reino» (ein Reich) que «leve a cabo a reconciliação de deus consigo no mundo»» (die Versöhnung Gottes mit sich vollbringe in der Welt), mas «não como um reino dos Céus, que está para além» (nicht als ein Himmelreich, das jenseits ist).

E a explicação subsequente é bastante elucidativa daquilo que com esta descida ao «terreno» se almeja, em termos de «realização» (Realisierung):

«Por outras palavras, as leis, costumes [Sitten], constituições de Estado, e o que em geral pertence à realidade [efectiva] da consciência espiritual, hão-de tornar-se racionais [vernünftig].» ${ }^{112}$.

A racionalidade é mesmo para realizar, e a realização consiste num objectivo ordenamento do mundo segundo uma figura racional.

E importa não descurar um matiz hegelianamente distintivo, que, por vezes, na leitura é esquecido, ou na interpretação deturpado.

\footnotetext{
${ }^{111}$ Hegel cita a tradução de Lutero: JOÃO, Evangelho, 18, 36.

112 «Mit anderen Worten, die Gesetze, Sitten, Staatsverfassungen, und was überhaupt zur Wirklichkeit des geistigen Bewußtseins gehört, soll vernünftig werden.», HEGEL, Vorlesungen über die Geschichte der Philosophie (1833-1836), II, Einleitung; TW, vol. 19, p. 501.
}

\begin{tabular}{|c|c|c|c|c|}
\hline Qonista Dialectus & Ano 5 & n. 12 & Janeiro - Julho 2018 & p. $46-108$ \\
\hline
\end{tabular}


A mensagem não se situa - e, sobremaneira, o processo não se desenrola -- ao nível de uma quimérica Ideia moralmente reguladora (das barricas de algum kantismo ensopado, entretanto, decantada) que, enquanto «dever-ser perene» (perennierendes Sollen $)^{113}$, houvesse de deambular pelas alturas, como normativo espectral, sem jamais ser atingido. Pelo contrário:

«Se uma Ideia houver de ser boa demais para a existência, então, isso é [uma] falta [Fehler] do próprio Ideal.» ${ }^{114}$.

O famoso brocardo da Rechtsphilosophie -- em inúmeras passagens retomado: «aquilo que é racional» (was vernünftig ist) «é [efectivamente] real»(das ist wirklich), «e aquilo que é [efectivamente] real» (und was wirklich ist) «é racional» (das ist vernünftig $)^{115}$-- não significa uma constatação aguabentada do existente, para que da sala de audiências saia incensado e absolvido ${ }^{116}$, mas, ao invés, consagra a exigência de um reconfiguramento histórico efectivo das positividades estabelecidas ${ }^{117}$, na, e pela, observância destes parâmetros.

${ }^{113}$ Cf. HEGEL, Wissenschaft der Logik (1812), I, I, 2, C, b; TW, vol. 5, p. 155.

114 «Soll eine Idee zur Existenz zu gut sein, so ist dies Fehler des Ideals selbst.», HEGEL, Vorlesungen über die Geschichte der Philosophie, I, I, 3, A, 3; TW, vol. 19, p. 110.

É perceptível a demarcação relativamente a certas interpretações vulgarizadas do kantismo, que, no entanto, dispunham de pista para o lançamento das unilateralidades no voo:

«Numa filosofia prática, [...] não temos de nos ocupar em admitir fundamentos [Gründe] daquilo que acontece [was geschieht], mas leis daquilo que deve acontecer [was geschehen soll], mesmo que isso nunca [niemals] aconteça» -- «In einer praktischen Philosophie, [...] es uns nicht darum zu tun ist, Gründe anzunehmen, von dem, was geschieht, sondern Gesetze von dem, was geschehen soll, ob es gleich niemals geschieht», KANT, Grundlegung zur Metaphysik der Sitten (1785), II; Ak., vol. IV, pp. $426-427$.

115 Cf. HEGEL, Grundlinien der Philosophie des Rechts, oder Naturrecht und Staatswissenschaft im Grundrisse (1821), Vorrede; TW, vol. 7, p. 24.

116 É neste sentido que «a história mundial» (die Weltgeschichte) igualmente devém «tribunal mundial» (Weltgericht). Cf. HEGEL, Enzyklopädie der philoaophischen Wissenschaften im Grundrisse (1830), § 548; TW, vol. 10, p. 347.

117 Por detrás da arquitectura vocabular imediatamente cordata, importa surpreender as dinâmicas, algo discordes, que se insinuam:

«Somente as nações germânicas chegaram, no Cristianismo, à consciência de que o ser humano como ser humano [é] livre, [à consciência] de que a liberdade do Espírito constitui a sua natureza mais própria. Esta consciência rompeu, primeiramente, na religião: na região mais interior do Espírito; porém, inculcar [einbilden] este princípio também na essência mundana [in das weltliche Wesen], isso era uma tarefa [um problema, eine Aufgabe] ulterior, para o resolver [lösen] e efectuar [ausführen] da qual é requerido um longo trabalho difícil da cultura [Bildung]. Com a adopção da religião cristã, não cessou imediatamente, por exemplo, a escravatura, nem, menos ainda, é logo, com ele, a liberdade dominante nos Estados, estão os governos e constituições organizados de uma maneira racional, ou foram até fundados sobre o princípio da liberdade. Esta aplicação do princípio à mundanidade, a enformação [die

\begin{tabular}{|l|l|l|l|l|}
\hline Qenista Dialectus & Ano 5 & n. 12 & Janeiro - Julho 2018 & p. 46-108 \\
\hline
\end{tabular}


Na Enciclopédia, deparamos com uma explicação algo arrevezada deste mesmo enunciado:

Pondo a desconto todas as inversões idealistas da forma, quanto ao fundamental, trata-se de «pro-duzir» (hervorbringen) -- como um objecto passível de «conhecimento» (Erkenntnis) numa instância real -- «a reconciliação da razão auto-consciente» (die Versöhnung der selbstbewußten Vernunft), que, na sua «interioridade», apenas se sabe enquanto princípio, «com a razão que é» (mit der seiende Vernunft), ou seja: «com a realidade [efectiva]» (mit der Wirklichkeit) ${ }^{118}$.

O idealismo dialéctico de Hegel, no seu formato de doutrina, representa decerto uma ontologia do «Espírito» (Geist). Não porque ele nos apareça encarrapitado como sobrepairante instância tutelar, mas porque somente na imanência dele «aquilo que é» acontece $^{119}$.

No entanto, para Hegel também, as colectividades humanas - designadamente, na figura cultural concreta dos «Povos» $(\text { Völker })^{120}$, e na forma política comunitária que

Durchbildung] e impregnação [Durchdringung] da situação mundana por ele, é o longo percurso que constitui a própria história.» -- «Erst die germanischen Nationen sind im Christentum zum Bewußtsein gekommen, daß der Mensch als Mensch frei [ist], die Freiheit des Geistes seine eigenste Natur ausmacht. Dies Bewußtsein ist zuerst in der Religion, in der innersten Region des Geistes aufgegangen; aber dieses Prinzip auch in das weltliche Wesen einzubilden, das war eine weitere Aufgabe, welche zu lösen und auszuführen eine schwere lange Arbeit der Bildung erfordert. Mit der Annahme der christlichen Religion hat z. B. nicht unmittelbar die Sklaverei aufgehört, noch weniger ist damit sogleich in den Staaten die Freiheit herrschend, sind die Regierungen und Verfassungen auf eine vernünftige Weise organisiert oder gar auf das Prinzip der Freiheit gegründet worden. Diese Anwendung des Prinzips auf die Weltlichkeit, die Durchbildung und Durchdringung des weltlichen Zustandes durch dasselbe ist der lange Verlauf, welcher die Geschichte selbst ausmacht.», HEGEL, Vorlesungen über die Philosophie der Geschichte $\left(1837,1840^{2}\right)$, Einleitung, B, a; TW, vol. 12, pp. 31-32.

118 Cf. HEGEL, Enzyklopädie der philosophischen Wissenschaften im Grundrisse (1830), § 6; TW, vol. 8, p. 47.

119 «O Espírito é aquilo que não apenas paira [schweben] sobre a história, como sobre as águas, mas que tece [weben] nela, e somente [ele] é o que [a] move [das Bewegende]» -- «der Geist ist es, der nicht nur über die Geschichte wie über den Wassern schwebt, sondern in ihr webt und allein das Bewegende ist», HEGEL, Enzyklopädie der philosophischen Wissenschaften im Grundrisse (1830), § 549; TW, vol. 10, p. 352.

$\mathrm{Na}$ alusão bíblica, para contraste invocada, reconhecem-se as palavras utilizadas por Lutero no traslado: «o Espírito de Deus pairava sobre a água» -- «der Geist Gottes schwebte auf dem Wasser», Génesis, 1, 2.

120 «A cultura de uma nação» (die Bildung einer Nation), enquanto «a forma da universalidade» (die Form der Allgemeinheit) à qual «tudo aquilo que é» (alles, was ist) é trazido, constitui, no seu «conteúdo determinado» (bestimmter Inhalt), «o Espírito do próprio Povo» (der Geist des Volkes selbst). Cf. HEGEL, Vorlesungen über die Philosophie der Geschichte $\left(1837,1840^{2}\right)$, Einleitung, B, c; TW, vol. 12, p. 69.

\begin{tabular}{|l|l|l|l|l|}
\hline Qovista Dialectus & Ano 5 & n. 12 & Janeiro - Julho 2018 & p. 46-108 \\
\hline
\end{tabular}


ao «Estado» (Staat), em cada estação do trajecto, venha a corresponder ${ }^{121}$-- constituem «os portadores» (die Träger $)^{122}$ da in-carnação histórico-mundana do próprio Geist, até porque (no seguimento, aliás, de uma matriz já em Spinoza posta a uso ${ }^{123}$ ) «a autoconsciência de deus»(das Selbstbewußtsein Gottes) apenas «se sabe no saber do ser humano» (sich in dem Wissen des Menschen weiß) ${ }^{124}$.

A brecha, porém, continua por preencher:

«O Espírito de Deus vive na comuna [in der Gemeinde]; ele é o Espírito interior que impele [der innere treibende Geist]. Mas é, no mundo, que o Espírito há-de ser realizado, num material [in einem Material] que ainda não lhe está conforme» ${ }^{125}$.

O programa hegeliano - a despeito, mas também através, do seu dialecticismo idealista, não desprovido de polissémicas ambiguidades -- dispunha a traça do projecto. Na pincelada larga do «teorético». Que concebe a «acção» sob o regime da «vontade».

121 Subsumindo a «naturalidade» doméstica da família, e a incontornável «cisão» (Entzweiung) que a «sociedade civil/burguesa» publicamente ex-põe:

«O Estado, em e para si, é o todo ético [das sittliche Ganze], a realização [die Verwirklichung] da liberdade, e é finalidade absoluta da razão que a liberdade seja [efectivamente] real. O Estado é o Espírito, que está no mundo e que, nele, se realiza com consciência» -- «Der Staat an und für sich ist das sittliche Ganze, die Verwirklichung der Freiheit, und es ist absoluter Zweck der Vernunft, daß die Freiheit wirklich sei. Der Staat ist der Geist, der in der Welt steht und sich in derselben mit Bewußtsein realisiert», HEGEL, Grundlinien der Philosophie des Rechts (1821), § 258, Zusatz; TW, vol. 7, p. 403.

122 «A auto-consciência de um povo particular é portadora [Träger] do estádio de desenvolvimento, nessa altura, do Espírito universal na sua existência [Dasein] e a [efectiva] realidade objectiva na qual ele depõe a sua vontade [Willen].»-- «Das Selbstbewußtsein eines besonderen Volkes ist Träger der diesmaligen Entwicklungsstufe des allgemeinen Geistes in seinem Dasein und die objektive Wirklichkeit, in welche er seinen Willen legt.», HEGEL, Enzyklopädie der philosophischen Wissenschaften im Grundrisse (1830), § 550; TW, vol. 10, p. 352 .

123 «A nossa mente, por quanto intelige, é um modo eterno do pensar, que por outro modo eterno do pensar é limitado [determinatur], e este, por sua vez, por um outro, e, assim, até ao infinito; de modo que todas [as mentes humanas] juntas [omnes simul] constituam o intelecto eterno e infinito de Deus.»-«Mens nostra, quatenus intelligit, aeternus cogitandi modus sit, qui alio aeterno cogitandi modo determinatur, et hic iterum ab alio, et sic in infinitum; ita ut omnes simul Dei aeternum et infinitum intellectum constituant.», Benedictus de SPINOZA, Ethica, ordine geometrico demonstrata (1677), Propositio XL, Scholium; Opera quotquot reperta sunt, ed. Johannes Van Vloten e Jan Pieter Nicolaas Land, Den Haag, Martinus Nijhoff, $1914^{3}$, vol. I, p. 271.

124 Cf. HEGEL, Vorlesungen über die Beweise vom Dasein Gottes (1829), 5; TW, vol. 17, p. 385.

125 «Der Geist Gottes lebt in der Gemeinde; er ist der innere treibende Geist. Aber es ist in der Welt, daß der Geist realisiert werden soll in einem Material, das ihm noch nicht gemäß ist», HEGEL, Vorlesungen über die Philosophie der Geschichte (1837, 1840²), IV, I, 1; TW, vol. 12, p. 427.

\begin{tabular}{|l|l|l|l|l|}
\hline Qenista Qialectus & Ano 5 & n. 12 & Janeiro - Julho 2018 & p. 46-108 \\
\hline
\end{tabular}


Sem as minúcias do pormenor. Com a Filosofia hasteada no mastro das regenerações em confiado aguardamento.

A revolução no Além-Reno francês permanecia intraduzida, entretanto, na outra banda de aquém, por onde o atrasado mundo da Germânia -- nem sequer como Estado «realizada» -- teimava em arrastar-se.

A juventude discipular, que no magistério de Hegel sorvia o sopro da inspiração, não demorou a aperceber-se de que lhe cumpria dar avanço à obra. Pelo menos, através do alçado de uma estacaria rebuçada em contornos remoçados.

O foco das preocupações desloca-se, em cadência de acelerado crescente - que a mocidade do querer precipita contra a decrepitude do envelhecido que resiste --, de um necessário pensamento da racionalidade lógica do conceito, para o tabuleiro histórico da igualmente necessária realização do racional.

O percutir da tecla, no domínio jurídico da explanação académica, é perceptível nas lições de Eduard Gans ${ }^{126}$, e, em clave antropo-teológica, transparece expressamente nas considerações finais da (para os delicados estômagos ortodoxos, também indigesta) Leben Jesu de David Friedrich Strauß ${ }^{127}$.

A meta que Feuerbach, desde cedo, se propõe -- constante de uma carta a Hegel de 1828, que acompanha o envio da tese de doutoramento em Erlangen: De ratione una, universali, infinita -- é «a realização e mundanização da Ideia» (die Verwirklichung und Verweltlichung der Idee), «a ensarcose ou incarnação do Logos puro» (die Ensarkosis oder Inkarnation des reinen Logos), por intermédio de procedimentos em que, pela

126 O combate está frontalmente dirigido contra a Escola Histórica do Direito, mas, na sua ambiguidade mesma, inclui acenos a outras paisagens:

«Se, por conseguinte, se quer ter uma verdadeira ciência do Direito [Rechtswissenschaft], tem que se apreender a Ideia [die Idee], e não se ficar por aquilo que os institutos [jurídicos] foram, mas o Direito tem que se fazer desenvolver a partir de si próprio. [...]. Pois, aquilo que não chega ao fenómeno [Erscheinung] é fraco [schwach], e aquilo que verdadeiramente é Ideia tem que apararecer [erscheinen].» -- «Will man daher eine wahre Rechtswissenschaft haben, so muß man die Idee auffassen und nicht dabei stehenbleiben, was die Instituten gewesen sind, sondern das Recht muß man sich aus sich selbst entwickeln lassen. [...]. Denn was nicht zur Erscheinung kommt, ist schwach, und was wahrhaft Idee ist, das muß erscheinen.», Eduard GANS, Naturrecht (1828-1829), Einleitung; Philosophischen Schriften, ed. Horst Schröder, Berlin, Akademie-Verlag, 1971, p. 43.

127 No quadro de uma Cristologia em endereço antropológico desenvolvida, «a humanidade toda» (die ganze Menschheit) tem que ser encarada como «a realização» (die Verwirklichung) da Ideia, «pois, se à Ideia não advém nenhuma realidade [efectiva], então, ela é [um] dever-ser vazio [leeres Sollen] e [um] Ideal [vazio].» -- «denn wenn der Idee keine Wirklichkeit zukommt, so ist sie leeres Sollen und Ideal.», STRAUSS, Das Leben Jesu kritisch bearbeitet (1835), § 147; ed. Werner Zager, Darmstadt, Wissenschaftliche Buchgesellschaft, 2012, vol. II, p. 734.

\begin{tabular}{|l|l|l|l|l|}
\hline Qenista Qialectus & Ano 5 & n. 12 & Janeiro - Julho 2018 & p. 46-108 \\
\hline
\end{tabular}


«presentificação imediata de ideias abstractas» (unmittelbare Vergegenwärtigung abstrakter Ideen), a Filosofia abandone um estatuto de mera «coisa da escola» (Sache der Schule) para se converter em «causa da humanidade» (Sache der Menschheit) ${ }^{128}$, em ordem a que finalmente se chegue à «dominação exclusiva da razão» (Alleinherrschaft der Vernunft $)^{129}$.

Segundo a perspectiva futurante que Moses $\mathrm{He} ß$ precocemente abraça, e da qual se assume como arauto, a cisão virá a desaparecer: «no tempo que se está a preparar [in der dazustellenden Zeit], Ideal e realidade são um [só, Eins]; a realidade torna-se ideial [conforme à Ideia, ideell], porque o Ideal é realizado.» ${ }^{130}$.

A ressurreição do racional (almejada) passa entretanto por uma impiedosa crítica do existente.

Numa série de artigos, reunidos depois numa brochura que dedicou a Marx, Karl Friedrich Köppen explorava a implicação:

«Aquilo que existe, e subsiste, e vigora, não deve mais vigorar porque é, mas porque é racional, e é como tal sabido; para a auto-consciência, ele não deve mais ser obscuro, mas claro; não [deve] mais estar fechado, mas manifesto; não [deve] mais ser uma essência estranha [fremd], mas a sua [essência] própria. O positivo [das Positive] deve tornar-se racional, e o racional [deve tornar-se] positivo, e, com isso, o ser humano [deve] deixar de ser um mero leigo, um crente, um submisso.» ${ }^{131}$.

\footnotetext{
${ }^{128}$ Como era conhecido -- mas por Hegel pouco apreciado --, Kant gostava de estabelecer uma distinção entre um «conceito escolar» (Schulbegriff) da filosofia, enquanto «o sistema dos conhecimentos de razão a partir de conceitos» (das System der Vernunfterkenntnisse aus Begriffen), e um seu alargado «conceito mundano» (Weltbegriff, conceptus cosmicus), em que ela devém, numa dignificada esfera de interesse vital, «a ciência da ligação de todo o conhecimento às finalidades essenciais da razão humana» (die Wissenschaft von der Beziehung aller Erkenntnis auf die wesentlichen Zwecke der menschlichen Vernunft). Cf. KANT, Kritik der reinen Vernunft $\left(1781,1787^{2}\right)$, Transzendentale Methodenlehre, 3 (A 838-839, B 866-867), e Logik (1800), Einleitung, III (Ak., vol. IX, pp. 23-24).

Para um enquadramento desta problemática, veja-se, por exemplo, o meu estudo: «Filosofia e Filosofar. Hegel versus Kant?», O outro Kant, Lisboa, Centro de Filosofia da Universidade de Lisboa, 2007, pp. 219-252.
}

${ }^{129}$ Cf. FEUERBACH, Brief an Hegel, 22. November 1828; GW, vol. 17, pp. 103-108.

130 «In der dazustellenden Zeit Ideal und Wirklichkeit Eins sind; die Wirklichkeit wird ideell, weil das Ideal verwirklicht wird.», Moses HESS, Die heilige Geschichte der Menschheit. Von einem Jünger Spinoza's (1837), III, 33; Philosophische und sozialistiche Schriften. 1837-1850. Eine Auswahl, ed. Wolfgang Mönke (doravante: PSS), Berlin, Akademie-Verlag, 1980², p. 66.

131 «Was da ist und besteht und gilt, soll nicht mehr gelten, weil es ist, sondern weil es vernünftig ist und als solches gewußt wird; es soll dem Selbstbewußtsein nicht mehr dunkel, sondern klar sein, nicht mehr verschlossen, sondern offenbar, nicht mehr ein fremdes, sondern sein eigenes Wesen. Das Positive soll

\begin{tabular}{|c|c|c|c|c|}
\hline Q Rovista Dialectus & Ano 5 & n. 12 & Janeiro - Julho 2018 & p. $46-108$ \\
\hline
\end{tabular}


E Bruno Bauer, em assomos vibrantes de «frontalidade» bombástica -- contra os ataques insinuosos dos restauracionistas, e a tibieza de outros sectores «críticos» que, «com a indigência dos seus princípios fundamentais não podiam suportar a luz do dia» (bei der Dürftigkeit ihrer Grundsätze das Tagelicht nicht ertragen konnten), pelo que na penumbra do secretismo buscavam refúgio --, punha a trombeta a tocar:

«Os hegelianos, em contrapartida, deitaram abaixo todo o sentimento [Gefühl], toda a religiosidade e piedade; eles estão decididos a derrubar todos os governos que contradigam o conceito [der Begriff] deles; o conceito deles está de um modo abarcante [umfassend], universal, consequente, por completo formado até ao pormenor, e dá-lhes uma força terrível» ${ }^{132}$.

As insuficiências do hegelianismo «oficialista» de estrita observância vêm, no entanto, cada vez mais ao de cima. Sobretudo, pelo contraste que se cava relativamente à maneira como os «jovens» empreendem o enfoque das questões.

«Esta viragem da teoria para a existência» (diese Wendung der Theorie auf die Existenz), no deliberado propósito de politicamente alcançar a tal realização do racional, devém, assim, no entender de Arnold Ruge, aquilo que precisamente está em falta «na política de Hegel» (in der Hegelschen Politik) ${ }^{133}$.

Heinrich Heine - auditor das lições de Hegel em Berlin, e, na altura, exilado em Paris - tinha, desde 1835, antevisto o recomendável circuito que as realidades alemãs haveriam de percorrer, e encontrado até para a ordenação desse giro uma justificação filosófico-histórica e etno-cultural:

«Afigura-se-me que um povo tão metódico como nós tinha que começar com a Reforma [Lutero], só depois podia ocupar-se da Filosofia [Kant], e, apenas após o

rational und das Rationale positiv werden und damit der Mensch aufhören, ein bloßer Laie, ein Gläubiger, ein Gehorsamer zu sein.», Karl Friedrich KÖPPEN, Zur Feier der Thronbesteigung Friedrichs II. (1840); Die Hegelsche Linke. Dokumente zu Philosophie und Politik im deutschen Vormärz, ed. Heinz Pepperle e Ingrid Pepperle (doravante: HL), Leipzig, Verlag Philipp Reclam jun., 1985, pp. 137-138.

132 «Die Hegelianer dagegen haben alles Gefühl, alle Religiosität und Pietät abgeworfen, sie sind entschieden, alle Regierungen zu stürzen, die ihrem Begriff widersprechen, ihr Begriff ist umfassend, allgemein, konsequent bis ins einzelne durchgebildet und gibt ihnen eine fürchterliche Kraft», Bruno BAUER, Die Posaune des jüngsten Gerichts über Hegel, den Atheisten und Antichristen (1841), V; HL, pp. 306-307.

133 Cf. Arnold RUGE, Die Hegelsche Rechtsphilosophie und die Politik unsrer Zeit. Erster Artikel (1842); HL, p. 460.

\begin{tabular}{|l|l|l|l|l|}
\hline Qevista Dialectus & Ano 5 & n. 12 & Janeiro - Julho 2018 & p. 46-108 \\
\hline
\end{tabular}


completamento [die Vollendung] dela [com Hegel], lhe era lícito transitar à revolução política. Acho esta ordem totalmente racional.» ${ }^{134}$.

Do poleiro da reacção ultramontana mirado, o panorama tomava entretanto uma outra coloratura. E, com alarmes de indignação pelo escândalo, os receios convertiam-se de dia para dia em denúncias com endereço indisfarçado:

«A partir da escola hegeliana, há-de viajar-se [befahren] a um revolucionamento [eine Umwälzung] dos conceitos religiosos e do Direito, e, em consequência disso, a um revolucionamento das formas eclesiais e de Estado» ${ }^{135}$.

$\mathrm{Na}$ vertente categorial, o instrumentário da accionalidade faz também, nestes contextos, a sua aparição. De resto, esperada, uma vez que a «realização» -- mesmo se de ideias - sempre requer o concurso de alguma instância mediadora.

August von Cieszkowski - num livro que, à época, não gozou de retumbância assinalada --, em apoio de uma «Historio-sofia» volvida à dimensão do futuro ${ }^{136}$, tece um conjunto de considerações interessantes, por onde a baforada de algum fichteanismo difuso é detectável, acerca de uma «práxis» auto-consciente que no «agir» há-de operar «a verdadeira síntese substancial do ser e do pensar» ${ }^{137}$.

134 «Mich dünkt, ein methodisches Volk wie wir mußte mit der Reformation beginnen, konnte erst hierauf sich mit der Philosophie beschäftigen und durfte nur nach deren Vollendung zur politischen Revolution übergehen. Diese Ordnung finde ich ganz vernünftig.», Heinrich HEINE, Zur Geschichte der Religion und Philosophie in Deutschland (1835), III; Werke, ed. Helmut Holtzhauer (doravante: W), Berlin-Weimar, Aufbau-Verlag, 1976 ${ }^{14}$, vol. 5, pp. 145-146.

135 «Von der hegelischen Schule aus eine Umwälzung der religiösen und Rechtsbegriffe und in Folge davon eine Umwälzung der Kirchen- und Staatsformen zu befahren sei», Heinrich LEO, Die Hegelingen. Actenstücke und Belege zu der s. g. Denunciation der ewigen Wahrheit (1838), Halle, Eduard Anton, $1839^{2}$, p. 1.

136 O problema já fora, de passagem, indicado por Kant:

«Como é, porém, possível uma história a priori? Resposta: quando o arúspice [der Wahrsager] faz ele próprio e organiza os acontecimentos que de antemão anuncia.» -- «Wie ist aber eine Geschichte $a$ priori möglich? Antwort: wenn der Wahrsager die Begebenheiten selber macht und veranstaltet, die er zum voraus verkündigt.», KANT, Der Streit der Fakultäten (1798), II, 1; Ak., vol. VII, pp. 79-80.

Faço notar que se trata, em Kant, da transferência para o mundo terreno de uma «solução» que dispunha de largo emprego cadastrado, mas na esfera teológica.

A dimensão activa, segundo um paradigma «volitivo» embora, poderia ter sido surpreendida, por Kant, em Hobbes:

«A previsão [the foresight] de coisas por vir - que é Providência - pertence unicamente àquele por cuja vontade elas hão-de vir.» -- «The foresight of things to come, which is Providence, belongs onely to him by whose will they are to come.», Thomas HOBBES, Leviathan, or The Matter, Forme, \& Power of a Common-Wealth Ecclesiasticall and Civill (1651), I, 3; ed. Crawford Brough Macpherson, Harmondsworth, Penguin Books, $1980^{10}$, p. 97.

137 «Chamamos, nomeadamente, factos [Thatsachen] (facta) àquelas datidades [Begebenheiten] passivas que nós, por assim dizer, encontramos, e para com as quais nos comportamos de um modo totalmente

\begin{tabular}{|l|l|l|l|l|}
\hline Qovista Dialectus & Ano 5 & n. 12 & Janeiro - Julho 2018 & p. 46-108 \\
\hline
\end{tabular}


Moses Heß - embora reivindicando para si próprio a precedência no achado (que na pioneira Heilige Geschichte der Menshheit, de 1837, deixara patenteado) - associa Cieszkowski àquele «trânsito positivo» (positiver Übergang) do pensamnto «para fora da filosofia alemã» (aus der deutschen Philosophie heraus) em direcção ao «acto» $(\text { That })^{138}$, que rasga em vaticínio as sendas do porvir ${ }^{139}$, e onde, assumindo uma herança «ética» de Spinoza, o elemento «activo» -- a partir de Fichte idealistamente repensado -apresenta contornos revolucionantes de distinta, e tinta, vocação socialista ${ }^{140}$.

indiferente: algo de existente [etwas Daseiendes] sem a nossa colaboração [ohne unsere Mitwirkung] e a nossa consciência. A estes [factos] tem decerto que se juntar a consciência, para os transformar em seus, e, nessa existência exterior, pesquisar uma essência interior. Acto [That] (actum), porém, é algo de totalmente outro: não é mais este acontecimento imediato que nós tínhamos meramente de recolher e de reflectir em nós; ele [o acto] já está reflectido, já [está] mediado, já [está] pensado: [é] pressuposto, e depois executado; é uma datidade activa que é totalmente nossa - não mais estranha [fremd], mas já consciente, ainda antes de ser realizada. Pode, portanto, dizer-se que os factos [die Facta] são datidades naturais, mas [que] os actos [die Thaten] são [datidades] artificiais [künstliche]. Os facta formam uma práxis inconsciente, portanto, pré-teorética; os actos, porém, [formam] uma [práxis] consciente, portanto, pós-teorética; porque a teoria entra no meio destas duas práticas [Praktiken], das quais a última, a saber: a práxis pós-teorética, se nos revela como a verdadeira síntese do teorético e do imediatamente prático, do subjectivo e do objectivo, na medida em que o agir [das Thun] em geral é a verdadeira síntese substancial do ser e do pensar.» -- «Thatsachen (facta) nämlich nennen wir diejenigen passiven Begebenheiten, die wir gleichsam vorfinden, und zu welchen wir uns ganz gleichgültig verhalten, etwas Daseiendes ohne unsere Mitwirkung und unser Bewußtsein. Zu diesen muss freilich das Bewußtsein hinzutreten, um sie in die sienigen umzuwandeln und in diesem äusserlichen Dasein ein inneres Wesen zu erforschen. That (actum) aber ist etwas ganz Anderes; es ist nicht mehr dieses unmittelbare Ereigniss, welches wir blos aufzunehmen und in uns zu reflectiren hatten, es ist schon reflectirt, schon vermittelt, schon gedacht, vorgesetzt und dann vollführt; es ist eine active Begebenheit, die ganz die unsrige ist, -- nicht mehr fremd, sondern schon bewusst, noch ehe sie verwirklicht wurde. Man kann also sagen, dass die Facta natürliche Begebenheiten, die Thaten aber künstliche sind. Die Facta bilden eine unbewusste, also vortheoretische, die Thaten aber eine bewusste, also nachtheoretische Praxis; weil die Theorie zwischen diese beide Praktiken in die Mitte tritt, welche letztere, nämlich die nachtheoretische Praxis, als die wahre Synthesis des Theoretischen und des unmittelbar Praktischen, des Subjectiven und Objectiven sich uns offenbart, indem das Thun überhaupt die wahre substantielle Synthesis des Seins und des Denkens ist.», August von CIESZKOWSKI, Prolegomena zur Historiosophie (1838), I; ed. Jan Garewicz, Hamburg, Felix Meiner Verlag, 1981, pp. 17-19.

${ }^{138}$ Cf. HESS, Die europäische Triarchie (1841), Einleitung; PSS, p. 83.

139 «A filosofia do acto é um germe do futuro com capacidade vital [ein lebensfähiger Keim der Zukunft], enquanto, pelo contrário, o Espírito "objectivo" de Hegel é, e permanece, pura Ideia.» -- «Die Philosophie der That ist ein lebensfähiger Keim der Zukunft, wohingegen Hegel's "objektiver" Geist pure Idee ist und bleibt.», HESS, Die europäische Triarchie (1841), Einleitung; PSS, p. 85.

140 «A base do acto livre é a Ética de Spinoza, e a presente filosofia do acto há-de ser apenas um ulterior desenvolvimento dela. Fichte colocou a pedra fundamental [der Grundstein] deste desenvolvimento para diante; mas a filosofia alemã, precisamente como tal, não podia sair para fora do idealismo. Para chegar ao socialismo, a Alemanha teria tido que ter também um Kant para o velho organismo da sociedade, como [teve] um para o pensar. Sem revolução, nenhuma história nova se começa.» -- «Die Basis der freien That ist die Ethik des Spinoza, und die vorliegende Philosophie der That soll eben nur eine weitere Entwickelung derselben sein. Fichte hat den Grundstein zu dieser Fortentwickelung gelegt; aber die deutsche Philosophie konnte als solche eben nicht über den Idealismus hinaus kommen. Um zum Sozialismus zu gelangen, hätte Deutschland auch einen Kant für den alten Organismus der Gesellschaft

\begin{tabular}{|c|c|c|c|c|}
\hline Q Rovista Dialectus & Ano 5 & n. 12 & Janeiro - Julho 2018 & p. $46-108$ \\
\hline
\end{tabular}


O tópico da «actividade» -- de diferentes maneiras entendido (mesmo quando frenéticas menções à Praxis sobrevêem recorrentemente) - estava, com efeito, na ordem do dia.

Em Deutschland - ein Wintermärchen, de 1844, Heine, em forma poética, dava testemunho desta presença surda, em fundo, sentida embora num certo modo, nostálgico ainda, de ausência.

«Na hora em que sentimentos mundanos brotam» (in der Stund, wo Weltgefühle sprießen), isto é, em que um interesse pela andança do mundo realmente se acende, há sempre um vulto misterioso em ronda, que sai da sombra, e que segreda, pedindo para não ser afastado:

«Eu não sou nenhum espectro do passado,/ nenhum espantalho saído da tumba,/ e da retórica não sou amigo nenhum,/ também não sou muito filosófico [sehr philosophisch].// Eu sou de natureza prática [von praktischer Natur],/ e sempre silencioso e tranquilo./ No entanto, fica a saber: aquilo que tu congeminaste no espírito, / isso levo eu a cabo, isso eu faço.// E mesmo que demore anos,/ eu não descanso até que eu transforme/ em realidade [in Wirklichkeit] aquilo que tu pensaste:/ tu pensas, e $\mathrm{eu}, \mathrm{eu}$ actuo $[$ ich handle].// [...] eu sou/ o acto do teu pensamento [die Tat von deinem Gedanken].» ${ }^{141}$.

Marx conhecia bem estes territórios de aventura. E as pistas pelos «realizadores da razão» trilhadas. Porque ele próprio, na esforçada caravana, os havia percorrido.

Sem descambo para tentadoras contaminações pelo «dever-ser» moralizante ${ }^{142}$, e sem capitulação perante enfunamentos da «imanência» accional subjectiva de fichteano

haben müssen, wie einen für's Denken. Ohne Revolution fängt sich keine neue Geschichte an.», HESS, Philosophie der That (1843); PSS, p. 221.

141 «Ich bin kein Gespenst der Vergangenheit,/ Kein grabenstiegener Strohwisch,/ Und von Rhetorik bin ich kein Freund,/ Bin auch nicht sehr philosophisch.// Ich bin von praktischer Natur,/ Und immer schweigsam und ruhig./ Doch wisse: was du ersonnen im Geist,/ Das führ ich aus, das tu ich.// Und gehn auch Jahre drüber hin,/ Ich raste nicht, bis ich verwandle/ In Wirklichkeit, was du gedacht;/ Du denkst, und ich, ich handle.// [...] ich bin/ Die Tat von deinem Gedanken.», HEINE, Deutschland - ein Wintermärchen (1844), VI; W, vol. 2, pp. 108-109.

142 A demarcação principial relativamente à «oposição do [efectivamente] real e do que há-de dever ser» (Gegensatz des Wirklichen und Sollenden), reconhecida como «ao idealismo [subjectivo] própria» (dem Idealismus eigen), ficou, desde cedo, efectuada:

«Do idealismo - que, diga-se de passagem, eu [tinha] comparado com o de Kant e o de Fichte, e [de que me tinha] alimentado --, fui dar comigo a procurar a Ideia no próprio [efectivamente] real. Se,

\begin{tabular}{|l|l|l|l|l|}
\hline Qenista Qialectus & Ano 5 & n. 12 & Janeiro - Julho 2018 & p. 46-108 \\
\hline
\end{tabular}


recorte $^{143}$, é certo. Mas, como no Differenzschrift se pode ler, com um combativo, e genuíno, «entusiasmo» hegelianista pelos estandartes da Filosofia:

anteriormente, os deuses tinham morado acima da Terra, agora, eles tinham-se tornado o centro dela.» -«Von dem Idealismus, den ich beiläufig gesagt, mit kantischem und fichte'schen verglichen und genährt, gerieht ich dazu, im Wirklichen selbst die Idee zu suchen. Hatten die Götter früher über der Erde gewohnt, so waren sie jetzt das Centrum derselben geworden.», MARX, Brief an Heintich Marx, 10./11. November 1837; MEGA $^{2}$, vol. III/1, pp. 15-16. Para o primeiro passo citado, veja-se: ibid., p. 10.

Entre os demais jovem-hegelianos, no entanto, era corrente interpretar a «Ideia» -- por Hegel, ou a partir de Hegel, pensada - como a expressão de um «dever-ser» (Sollen) a brandir nas confrontações com o existente: com o «ser» (Sein).

Citando a hegeliana afirmação de que:

«Através do saber, o Espírito põe uma diferença entre o saber e aquilo que é [das, was ist]»-«Durch das Wissen setzt der Geist einen Unterschied zwischen das Wissen und das, was ist», HEGEL, Vorlesungen über die Geschichte der Philosophie (1833-1836), Einleitung, B, 1, c; TW, vol. 18, p. 75 --, Bruno Bauer, por exemplo, comenta:

«A filosofia é, por conseguinte, crítica do subsistente. [...]. Diferencia-se aquilo que existe [das, was da ist] e aquilo que deve ser. Somente o dever-ser, porém, é o verdadeiro, [o] justificado, e tem que ser levado a vigorar [zur Geltung], [à] dominação, e [ao] poder [Gewalt]. [...]. Ele tem, portanto, que chegar ao acto [zur Tat], à oposição prática, e um princípio teorético tem que se tornar práxis e acto, não apenas posteriormente, ou por um desvio, mas directamente [geradezu].»-- «Die Philosophie ist demnach Kritik des Bestehenden. [...]. Das, was da ist und was sein soll, wird unterschieden. Das Sollen aber ist allein das Wahre, Berechtigte und muß zur Geltung, Herrschaft und Gewalt gebracht werden. [...]. Es muß also zur Tat kommen, zur praktischen Opposition, und nicht nur nachträglich oder auf einem Umwege, sondern geradezu muß ein theoretisches Prinzip Praxis und Tat werden.», Bruno BAUER, Die Posaune des jüngsten Gerichts (1841), IV; HL, p. 301.

E, numa direcção aparentada, se encaminha também Arnold Ruge, quando contrasta «o dever-ser da Ideia» (das Sollen der Idee) com «a realidade empírica» (die empirische Wirklichkeit) criticanda - cf. RUGE, Vorwort zum Jahrgang 1841 der Deutschen Jahrbücher (1841); HL, p. 225 --, ou quando reclama que «o dever-ser pleno de conteúdo do presente histórico que a si próprio se conhece» (das inhaltsvolle Sollen der sich selbst erkennenden geschichtlichen Gegenwart) não é mais do que «o dever-ser divino» (das göttliche Sollen), «a dialéctica da história» (die Dialektik der Geschichte), «o futuro presente» (der gegenwärtige Zukunft): cf. RUGE, Zur Kritik des gegenwärtigen Staats- und Völkerrechts (1840); HL, p. 153.

143 A esta luz há-de ser lido aquele reparo adversativo que na ponta final do encómio juvenil de Epicuro transparece:

«A absolutidade e liberdade da auto-consciência é o princípio da filosofia de Epicuro, ainda que a auto-consciência seja aprerendida apenas sob a forma da singularidade.» -- «Die Absolutheit und Freiheit des Selbstbewußtseins ist das Princip der epikureischen Philosophie, wenn auch das Selbstbewußtsein nur unter der Form der Einzelheit gefaßt wird.», MARX, Differenz des demokritischen und epikureischen Naturphilosophie (1841), II, 5; MEGA², vol. I/1, p. 57.

Veja-se, além disso, o comentário acerca da «imanência» (Immanenz) fichteanamente enfunada «com o seu Eu criador de mundo» (mit seinem Weltschöpferischen Ich), que «não pode criar mundo nenhum»(keine Welt schaffen könne): cf. MARX, Hefte zur epikureischen Philosophie (1839), V, 6; $\mathrm{MEGA}^{2}$, vol. IV/1, pp. 102-103. A subsequente alusão ao «ironismo» supõe o hegeliano tratamento crítico do tema, pela poética romântica (Friedrich von Schlegel), entretanto, repescado: cf. HEGEL, Vorlesungen über die Geschichte der Philosophie (1833-1836), I, I, 2, B, 1; TW, vol. 18, p. 460.

A navegação de Ruge, por exemplo, ia-se fazendo por outras águas.

Ao joverm-hegelianismo estaria cometida a tarefa de desenvolver «um idealismo novo» (ein neuer Idealismus), entendido como «a consequência necessária da autonomia da vontade de Kant, do Eu que se autodetermina de Fichte, e da exegese [Auslegung] de Hegel daquela inteligência [Intelligenz] que se autodetermina a si própria, quer dizer: da dialéctica do conceito, [que se autodetermina] tanto em pura auto-consciência, como em Espírito (Estado e história)» -- «die notwendige Konsequenz der Kantischen Autonomie des Willens, des Fichtischen sich selbstbestimmenden Ichs und der Hegelschen Auslegung dieser sich selbstbestimmenden Intelligenz, d. h. der Dialektik des Begriffs, sowohl im reinen

\begin{tabular}{|c|c|c|c|c|}
\hline Q Rovista Qialectus & Ano 5 & n. 12 & Janeiro - Julho 2018 & p. $46-108$ \\
\hline
\end{tabular}


«Tal como Prometeu que, roubado o fogo do Céu, começa a construir casas e a estabelecer-se na Terra, também a Filosofia, que se estendeu ao mundo, se vira contra o mundo fenoménico [gegen die erscheinende Welt, isto é, o existente]. [Acontece] assim, agora, com a [filosofia] de Hegel.» ${ }^{144}$.

E, segundo a terminologia neste período empregue, cabe igualmente à Filosofia, no seu exercício crítico da positividade fenomenalizada, medir «a existência singular pela essência, a [efectiva] realidade particular pela Ideia» (die einzelne Existenz am Wesen, die besondere Wirklichkeit an die Idee $)^{145}$.

Acusando crescentes contornos de concretude determinada - e, cada vez menos, descaindo para uma convocatória em abstracto -- o tema da «realização» continua a ser perceptível nos escritos da juventude de Marx.

$\mathrm{Na}$ crítica dos restauracionistas intentos pios de uma «re-teologização» forçada de apodrecidos ordenamentos políticos:

«O Estado é de reconstruir, não a partir da religião, mas a partir da razão da liberdade [aus der Vernunft der Freiheit]» ${ }^{146}$.

$\mathrm{Na}$ impiedosa desmontagem dos arraiais montados por Gustav Hugo, e pela «Escola Histórica do Direito» (Historische Rechtsschule), no desgraçado intento de

Selbstbewußtsein als im Geist (Staat und Geschichte).», RUGE, Vorwort zum Jahrgang 1841 der Deutschen Jahrbücher (1841); HL, p. 227. Em todas estas pendências, a fim de sacudir do seu torpor «a preguiçosa contemplatividade do hegelianismo» (die faule Beschaulichkeit des Hegelianismus), haveria que ressuscitar «a força do acto de Fichte» (die Fichtesche Tatkraft): cf. RUGE, Zur Kritik des gegenwärtigen Staats- und Völkerrechts (1840); HL, p. 153.

Mais tarde, não passará sem a devida observação crítica o facto de Bruno Bauer -- na sua «autoconsciência» confortavelmente empoleirado -- proceder a uma teológica leitura de Hegel «do ponto de vista de Fichte» (auf Fichteschen Standpunkt). Cf. ENGELS-MARX, Die heilige Familie (1845), VI, 3, f; MEW, vol. 2, p. 147, bem como: MARX-ENGELS, Die deutsche Ideologie (1845-1846), I, II, 1; MEW, vol. 3, p. 82 .

144 «Wie Prometheus, der das Feuer vom Himmel gestohlen, Häuser zu bauen und auf der Erde sich anzusiedeln anfängt, so wendet sich die Philosophie, die zur Welt sich erweitert hat, sich gegen die erscheinende Welt. So jetzt die Hegelsche.», MARX, Hefte zur epikureischen Philosophie (1839), V, 6; $\mathrm{MEGA}^{2}$, vol. IV/1, p. 99.

145 Cf. MARX, Differenz des demokritischen und epikureischen Naturphilosophie (1841), Anmerkungen zum Ersten Teil, IV; MEGA², vol. I/1, p. 68.

146 «Der Staat nicht aus der Religion sondern aus der Vernunft der Freiheit zu konstruiren ist», MARX, Der leitende Artikel in Nr. 179 der Kölnischen Zeitung (1842); MEGA², vol. I/1, p. 188.

\begin{tabular}{|c|c|c|c|c|}
\hline Qovista Dialectus & Ano 5 & n. 12 & Janeiro - Julho 2018 & p. $46-108$ \\
\hline
\end{tabular}


«fazer passar por plenamente válido» (für vollgültig passiren lassen) «o inverdadeiro, desde que exista» (das Unwahre, wenn es nur existirt $)^{147}$.

Em avulsos reparos, de aparente incidência tão-só paroquial:

«Os alemães são, por natureza, sumamente devotos, submissos, respeitosos. Por puro respeito para com as ideias, não as realizam.» ${ }^{148}$.

Ou até mesmo no espinhoso memorando de réplica ao encerramento compulsivo da Rheinische Zeitung pelas autoridades prussianas, onde, como fundamento da defesa, se alega que ela - entendendo «a democracia, no sentido de que o ser humano livre háde ser o princípio do Estado» (die Demokratie in dem Sinne, daß der freie Mensch das Prinzip des Staates sein solle) - se limitava a «exigir» (verlangen) que «as condições de uma comunidade racional e ética [estivessem] realizadas no Estado» (die Bedingungen eines vernünftigen und sittlichen Gemeinwesens im Staat verwirklicht $)^{149}$.

No entanto, o amadurecimento ontológico, político, e prático, das questões, e da sua implantação histórica efectivamente real, ia conduzindo também a pesquisa para patamares de outra fundura.

147 Cf. MARX, Das philosophische Manifes der historischen Rechtsschule (1842); MEGA ${ }^{2}$, vol. I/1, p. 192.

Nos Deutsch-Französische Jahrbücher, o mesmo ajuizamento -- que não prima pela meiguice -voltará a ser expresso em termos que revelam algum avanço na densidade analítica:

«Uma Escola que legitima a infâmia de hoje pela infâmia de ontem; uma Escola que declara como rebelde cada grito do servo contra o chicote, desde que o chicote seja um chicote com muitos anos, um [chicote] hereditário, um [chicote] histórico; uma Escola à qual a história, tal como o deus de Israel ao seu servidor Moisés, apenas mostra o seu a posteriori [leia-se: o traseiro]: a Escola Histórica do Direito teria, por conseguinte, inventado a história alemã, se não fosse ela [mesma] uma invenção da história alemã.» -- «Eine Schule, welche die Niederträchtigkeit von heute durch die Niederträchtigkeit von gestern legitimirt, eine Schule, die jeden Schrei des Leibeigenen gegen die Knute für rebellisch erklärt, sobald die Knute eine bejahrte, eine angestammte, eine historische Knute ist, eine Schule, der die Geschichte, wie der Gott Israels seinem Diener Moses, nur ihr a posteriori zeigt, die historische Rechtsschule, sie hätte daher die deutsche Geschichte erfunden, wäre sie nicht eine Erfindung der deutschen Geschichte.», MARX, Zur Kritik der Hegelschen Rechtsphilosophie. Einleitung (1844); MEGA², vol. I/2, p. 172.

Para o episódio vetero-testamentário acerca da divina predilecção por um posicionamento dorsal, veja-se: Livro do Exxodo, 33, 23.

Para desenvolvimentos em torno desta problemática -- ao tempo, verdadeiramente fracturante, no arrumar das posições --, veja-se, por exemplo, o meu livro: Marx e a crítica da «Escola Histórica do Direito», Lisboa, Editorial Caminho, 1994.

148 «Die Deutschen sind von Natur devotest, allerunterthänigst, ehrfurchtsvollst. Aus lauter Respekt vor den Ideen verwirklichen sie dieselben nicht.», MARX, Die Verhandlungen des 6. Rheinischen Landtags. Erster Artikel. Debatten über Preßfreiheit und Publikation der Landständischen Verhandlungen (1842); $\mathrm{MEGA}^{2}$, vol. I/1, p. 160.

149 Cf. MARX, Denkschrift betreffend die Unterdrückung der «Rheinischen Zeitung» (1843), III; MEGA $^{2}$, vol. I/1, p. 401.

\begin{tabular}{|l|l|l|l|l|}
\hline Qenista Qialectus & Ano 5 & n. 12 & Janeiro - Julho 2018 & p. 46-108 \\
\hline
\end{tabular}


Nem as «ideias» dispõem de subsistência autónoma, nem tudo se resume a uma mera «actualização» enérgica de ideatos de antemão pré-fixados.

A luta teorética tem o seu lugar e a sua função próprios, sem dúvida. Mas, a montante e a juzante do sítio onde se travam, esses combates não estão desprovidos de radicação noutros enquadramentos:

«Mesmo como adversária [Widerpart] decidida do modo da consciência política alemã até agora, a crítica da Filosofia especulativa do Direito não desemboca em si própria [in sich selbst], mas em tarefas [Aufgaben], para cuja solução há apenas um meio: a prática [die Praxis].» ${ }^{150}$.

Nos Manuscritos de 1844, apesar das «hesitações» relativamente ao emprego da categoria «materialismo», a perspectiva aprofunda-se:

«Vê-se como a solução das próprias oposições teoréticas só é possível de uma maneira prática [auf eine praktische Art], só [é possível] através da energia prática do ser humano, e, por conseguinte, a sua solução não é de modo nenhum apenas uma tarefa do conhecimento [eine Aufgabe der Erkenntnis], mas [é] uma tarefa [efectivamente] real do viver [eine wirkliche Lebensaufgabe], a qual a filosofia não podia resolver, porque, precisamente, a apreendia como tarefa apenas teorética.» ${ }^{151}$.

Na prossecução deste itinerário atribulado, as Teses vêm, por sua vez, a clarificar o reposicionamento dos problemas numa base, e num horizonte, dialéctico materialista.

Não basta a teoria, mesmo que correctamente fundada (isto é, assegurando ao pensar realidade efectiva).

Não basta o entusiástico pregão da «accionalidade», instantemente cantada em coro, a cada esquina, nos vocalizos mais díspares.

Importa, sim, e sobremaneira, o carácter materialmente transformador da prática -- em cujo processo vital concreto a dimensão do pensamento se inscreve --, e, de igual

150 «Schon als entschiedner Widerpart der bisherigen Weise des deutschen politischen Bewußtseins, verläuft sich die Kritik der spekulativen Rechtsphilosophie nicht in sich selbst, sondern in Aufgaben, für deren Lösung es nur ein Mittel gibt: die Praxis.», MARX, Zur Kritik der Hegelschen Rechtsphilosophie. Einleitung (1844); $\mathrm{MEGA}^{2}$, vol. I/2, p. 177.

151 «Man sieht, wie die Lösung der theoretischen Gegensätze selbst nur auf eine praktische Art, nur durch die praktische Energie des Menschen möglich ist und ihre Lösung daher keineswegs nur eine Aufgabe der Erkenntniß, sondern eine wirkliche Lebensaufgabe ist, welche die Philosophie nicht lösen konnte, eben weil sie dieselbe als nur theoretische Aufgabe faßte.», MARX, Ökonomisch-philosophische Manuskripte (1844), Heft III, Ergänzungen zu Heft II, Privateigentum und Kommunismus; MEGA ${ }^{2}$, vol. $\mathrm{I} / 2$, p. 395.

\begin{tabular}{|l|l|l|l|l|}
\hline Qevista Dialectus & Ano 5 & n. 12 & Janeiro - Julho 2018 & p. 46-108 \\
\hline
\end{tabular}


modo, importa a compreensão determinada dos agentes susceptíveis de levarem a cabo as transformações.

Em A sagrada família - tendo à mão uma tirada, tão vibrante quanto oca, de Bruno Bauer ${ }^{152}$--, Marx aproveitara a crítica para recolocar a questão no seu verdadeiro pé:

«Ideias nunca podem levar para além de [hinausführen über] um velho estado do mundo, mas sempre apenas para além das ideias do velho estado do mundo. Ideias não podem, de modo nenhum, levar a cabo nada [nichts ausführen]. Para o levar a cabo das ideias são precisos os seres humanos, que empregam uma violência prática [eine praktische Gewalt].» ${ }^{153}$.

$\S 10$. Coda.

Não é resumo. É, porventura, o sumo.

Começando pelo fim, o que é também uma maneira de acabar:

Um pensar que se imagine isolado da prática carece de realidade. E dificilmente encontrará realização.

Poderá como ficção ser indagado, e, como tal, desempenhar o seu papel.

Todo o pensar, enquanto actividade humana específica, se dá no interior de um viver, que é constitutivamente prático. O pensar é uma função vital, e ela, radicalmente, é um processo de trocas materiais com o mundo e com os outros.

Sem todo um contorno de materialidade, não há cabeça que pense, nem pensar que se exercite. Mesmo quando no «além» a cogitação seja posta, é sempre desde um «aquém», e para um «aquém», que se pensa.

152 Referindo-se à Revolução Francesa - e não escondendo a sua indignação «auto-consciente» pelos «massificadores» resultados por ela produzidos --, Bruno Bauer dispara:

«As ideias por ela impelidas para diante não levaram, porém, para além do estado [de coisas, Zustand] que ela com violência [mit Gewalt] queria suprimir» -- «die Ideen, die sie hervorgetrieben hatte, führten aber über den Zustand, den sie mit Gewalt aufheben wollte, nicht hinaus», Bruno BAUER, Was ist jetzt der Gegenstand der Kritik? (1844); FrK, p. 209.

153 «Ideen können nie über einen alten Weltzustand, sondern nur immer über die Ideen des alten Weltzustandes hinausführen. Ideen können überhaupt nichts ausführen. Zum Ausführen der Ideen bedarf es der Menschen, welche eine praktische Gewalt aufbieten.», ENGELS-MARX, Die heilige Familie (1845), VI, 3, c; MEW, vol. 2, p. 126.

\begin{tabular}{|l|l|l|l|l|}
\hline Qenista Qialectus & Ano 5 & n. 12 & Janeiro - Julho 2018 & p. 46-108 \\
\hline
\end{tabular}


Segundo e complementar aspecto:

No plano da teoria só, não é possível decidir a questão da verdade objectiva que um determinado pensamento possua.

Antes do mais, porque essa verdade diz respeito a estados-de-coisas e processos materiais (sem o que não seria «objectiva»); não trata apenas da coerência «lógica» das «ideias», ou da «bondade» dos desideratos.

Por outro lado, e como determinante vector:

A verdade objectiva de uma teoria mede-se: na prática - Marx não se limita a dizer: na experiência --, isto é, no poder que ela revela (não apenas imediatamente) de transformar realidades.

O critério da verdade é a materialização da transformação; não consiste na mera «constatação» teórica (ainda que empiricamente dada) de que um determinado facto ou processo ocorreu.

Aquilo que prova é a feitura, e não apenas a «consciência» que se tenha dela. E este constitui o registo decisivo.

Por isso é que, sob este ponto de vista, o marxismo não é nem um «empirismo» (em que a verdade devém mera comprovação de positividades), nem um «eticismo» (em que a proclamação do «dever-ser» dispensa a boa consciência de outros trabalhos), nem um «pragmatismo» (em que como verdade vale tudo aquilo que «funcione», ou que «sirva» um determinado propósito), mas uma concepção que, a partir da materialidade dialéctica do real, o procura compreender teoricamente (reflectindo, de modo adequado, na sua concreção, as dinâmicas de que se entretece), e transformar praticamente num sentido revolucionário (afinando e confirmando assim, na prática, o valor de realidade, o valor de verdade, do seu pensamento).

Lisboa, Março-Abril de 2017. 